\title{
UMA SISTEMÁTICA DE MANUTENÇÃO PARA O GERENCIAMENTO E CONTROLE DE PARADAS PLANEJADAS EM PROCESSOS DE PRODUÇÃO DE CELULOSE E PAPEL
}

\section{Fabrício Rogério Parrilla}
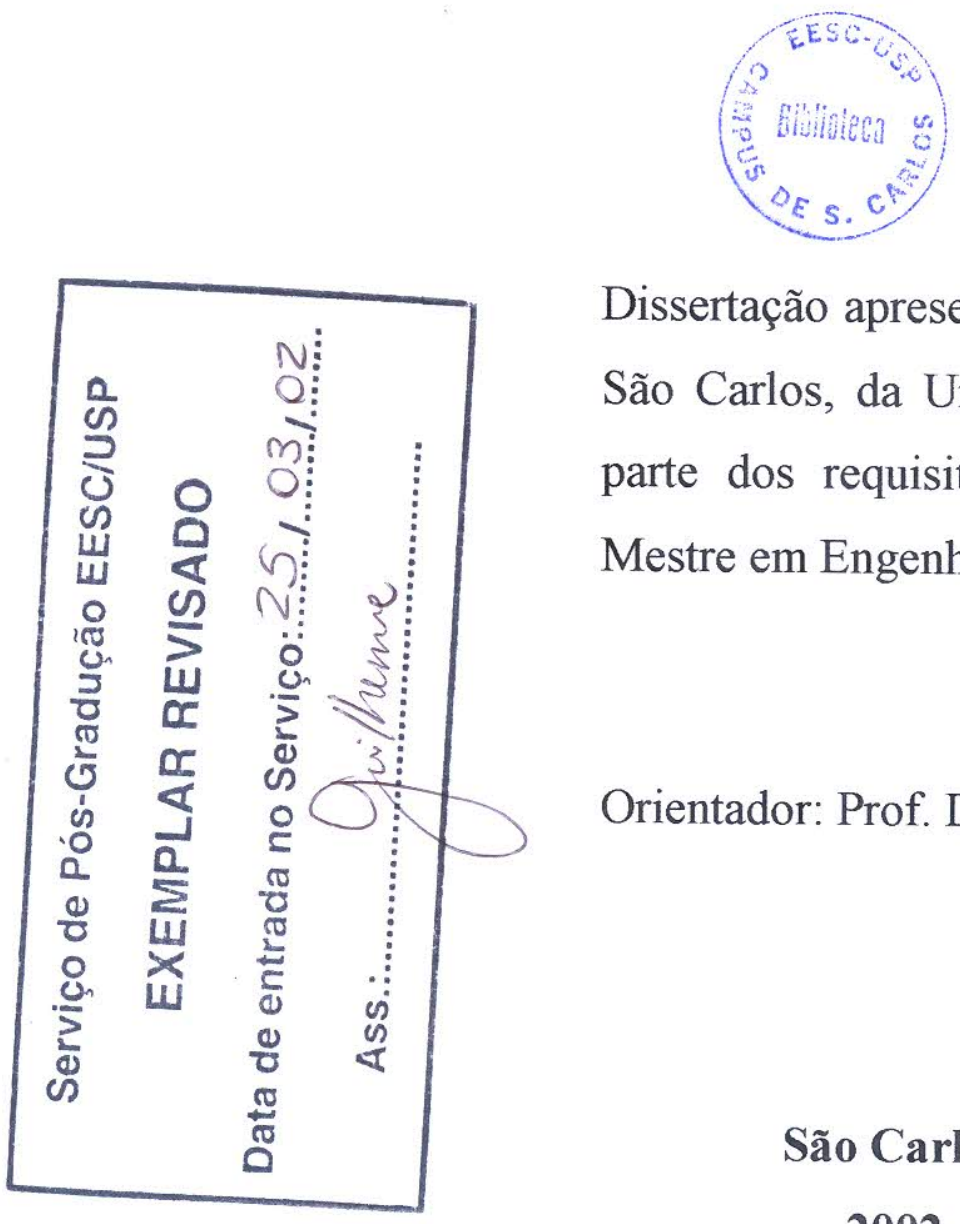

Dissertação apresentada à Escola de Engenharia de São Carlos, da Universidade de São Paulo, como parte dos requisitos para obtenção do título de Mestre em Engenharia de Produção.

Orientador: Prof. Dr. Renato Vairo Belhot

São Carlos

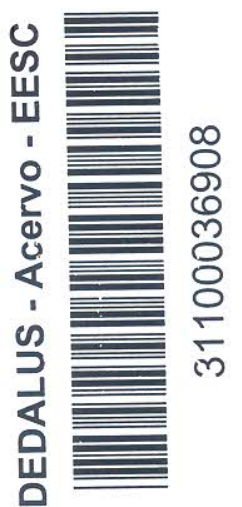


Parrilla, Fabrício Rogerio

Uma sistemática de manutenção para o gerenciamento e controle de paradas planejadas em processos de produçăo de celulose e papel / Fabricio Rogério Parrilla. -- Săo Carlos, 2002.

Dissertaçăo (Mestrado) -- Escola de Engenharia de săo Carlos-Univerildade de săo Paulo; 2002.

Área: Engenharia de produçăo.

Orientador: Prof. Dr. Renato Vairo Belhot.

1. Manutenço. 2. Gerenciamento de manutenção. 3. Paradas planejadas. 4. Celulose - papel. I. TItulo. 
Candidato: Engenheiro FABRICIO ROGERIO PARRILLA

Dissertação defendida e julgada em 08-03-2002 perante a Comissão Julgadora:

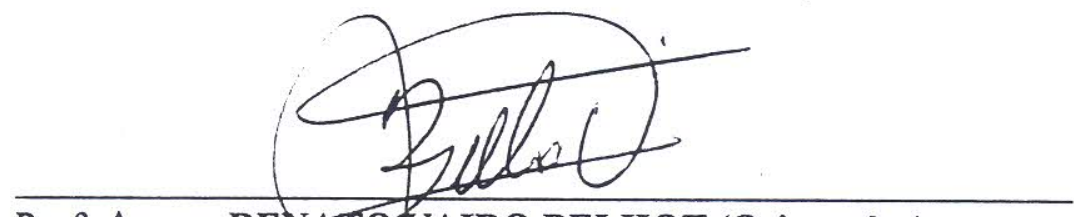

\section{APROVADO}

Prof. Assoc. RENTTO VAIRO BELHOT (Orientador)

(Escola de Engenharia de São Carlos/USP)

APROVADO

Prof. Assoc. LUIZ CESAR RIBEIRO CARPINETTI

(Escola de Engenharia de São Carlos/USP)

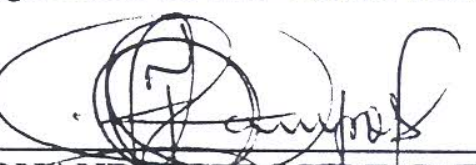

APROVADO

Prof. Dr. FERNAND PeETSO PECAMPOS

(Instituição Moura Lacerda)

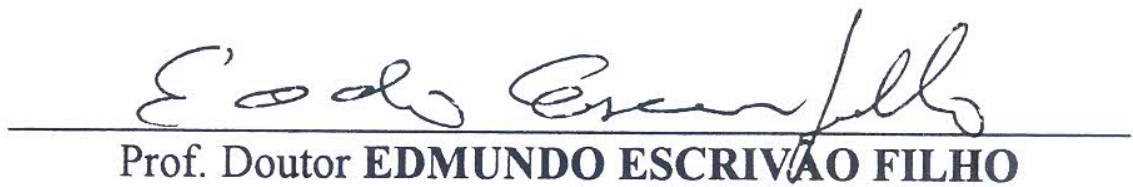

Coordenador do Programa de Pós-Graduação em Engenharia de Produção

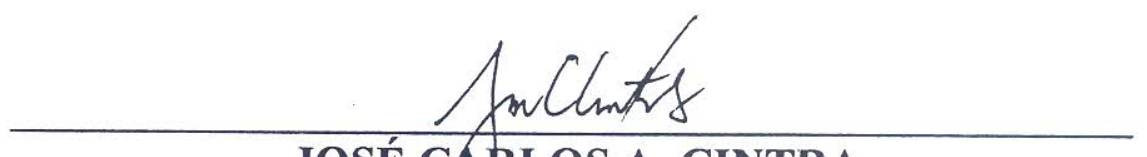

JOSÉ CARLOS A. CINTRA

Presidente da Comissão de Pós-Graduação da EESC 
À José Parrilla (in memorian), meu avô, pelas inesquecíveis lições de otimismo, alegria e perseverança. 
À Wilson e Ideleusa, meus pais, fundamentais em todas as minhas conquistas.

À querida Marlene, minha esposa e fonte de inspiração, que em muito contribuiu para a realização deste sonho. 


\section{AGRADECIMENTOS}

Desejo registrar minha estima e agradecimentos:

Ao Prof. Renato Vairo Belhot, pela paciência, atenção, orientação e mensagens de sabedoria e confiança, imprescindíveis para a realização desta dissertação.

Aos Profs. Fernando C. Campos e Luiz Cesar R. Carpinetti, pela contribuição e avaliação altamente crítica no exame de qualificação.

Ao Líder Ezequiel Dovico, grande amigo e um profissional excepcional, pelo exemplo positivo, apoio incondicional e discussões enriquecedoras.

Aos colegas de trabalho da Unidade Luiz Antônio do Grupo Votorantim Celulose e Papel, com quem pude discutir, vivenciar e avançar na temática deste trabalho.

Aos professores e colegas da área de Engenharia de Produção da Escola de Engenharia de São Carlos, com quem muito aprendi e compartilhei da magia da pesquisa acadêmica.

À Universidade de São Paulo, pela oportunidade de concretizar o sonho e o desafio do Mestrado.

E sobretudo a Deus. 


\section{SUMÁRIO}

LISTA DE FIGURAS ix

LISTA DE ABREVIATURAS E SIGLAS X

RESUMO Xiii

ABSTRACT Xiv

1. INTRODUÇÃO 01

$\begin{array}{ll}\text { 1.1. Visão Geral do Setor Papeleiro } & 01\end{array}$

1.2. A Função Manutenção nesse Ambiente $\quad 02$

$\begin{array}{ll}\text { 1.3. As Paradas Planejadas } & 04\end{array}$

1.3.1. Uma necessidade do processo de fabricação 05

1.3.2. O momento da equipe de manutenção 08

1.4. Caracterização do Problema 09

1.5. Objetivo 11

1.6. Desenvolvimento e Estruturação da Dissertação 12

2. O MERCADO E O PROCESSO DE FABRICAÇÃO DE CELULOSE

$\begin{array}{ll}\text { E PAPEL } & 14\end{array}$

2.1. Origem, Evolução e Cenário Atual do Setor Papeleiro no Mundo 14

2.2. A Indústria Papeleira no Brasil 19

2.3. O Grupo Votorantim Celulose e Papel - VCP 22

2.3.1. A Unidade Luiz Antônio - Visão geral da organização e do processo de fabricação $\quad 25$

2.3.2. A produção de utilidades $\quad 30$

2.3.3. O processo de recuperação química 32

2.3.4. A produção da celulose e do papel 34

2.3.5. Controle do meio ambiente 35 
3. A MANUTENÇÃO NO SETOR PAPELEIRO 37

3.1. Introdução 37

3.2. Uma Política de Manutenção Efetiva 38

3.2.1. Práticas básicas de manutenção $\quad 41$

3.2.2. Engenharia de manutenção 44

3.2.3. Manutenção centrada em confiabilidade 44

3.2.4. Gerenciamento, planejamento e controle de manutenção 46

3.2.5. Análise de árvore de falhas (FTA) 49

3.2.6. Análise de modo e efeito de falha (FMEA) e das causas raízes da falha $(R C F A) \quad 50$

3.2.7. Análises de problemas (APP) e riscos potenciais (ARP) 51

3.3. A Qualidade Total 53

3.3.1. A prática do $5 S$ (Housekeeping) 55

3.3.2. A Metodologia Kaizen 56

3.3.3. Manutenção produtiva total (TPM) 57

3.3.4. O gerenciamento da rotina (Ciclos PDCA e SDCA) 59

3.3.5. Normas ISO (Série 9000) 61

3.4. Sistemas Informatizados de Apoio à Manutenção 62

3.5. Os Recursos Humanos e a Cultura da Organização 65

3.5.1. O homem de manutenção $\quad 68$

3.6. A Gestão da Manutenção 70

3.6.1. A gestão compartilhada do processo produtivo 72

3.6.2. A estratégia de intervenções na planta fabril 73

\section{O GERENCIAMENTO E CONTROLE DE PARADAS}

PLANEJADAS

4.1. Introdução 75

4.2. Algumas Abordagens 75

4.2.1. Controle dinâmico de grandes reparos - TAVARES 76

4.2.2. Planejamento e controle de paradas de manutenção - VIANNA 77

4.2.3. Planejamento e controle de paradas - VERRY 79

4.2.4. Shutdowm and outage management-DRESSER \& CANIPE 81 
4.2.5. Sistema de gestão de paradas programadas - ABS Serviços 83

4.3. Análise Comparativa 85

4.4. Uma Verificação na Prática - Parada Geral 2001 (PG2001) da

VCP_LA 86

4.4.1. Visão geral do ambiente da verificação $\quad 87$

4.4.2. Impactos e interfaces entre os processos $\quad 88$

4.4.3. O desenvolvimento da parada geral $\quad 90$

4.4.4. Resultados da parada e análise 102

4.4.5. Alguns fatores de risco observados 105

4.4.6. Considerações da verificação na prática 106

5. UMA SISTEMÁTICA DE MANUTENÇÃO PARA O GERENCIAMENTO DE PARADAS PLANEJADAS 108

5.1. Introdução 108

5.2. A Concepção e o Desenvolvimento da Sistemática 111

5.2.1. O modelo 112

5.3. O Detalhamento das Etapas da Sistemática 113

5.3.1. Etapa 1 - Estabelecimento da estratégia 115

5.3.2. Etapa 2 - Planejamento e programação 116

5.3.3. Etapa 3 - Controle da execução 127

5.3.4. Etapa 4 - Avaliação e perspectivas 135

6. CONCLUSÕES E PERSPECTIVAS 138

6.1. Conclusões Gerais da Pesquisa Desenvolvida 138

6.2. Impactos Esperados para o Negócio 140

6.3. Contribuições da Sistemática para a Manutenção 144

6.4. A Manutenção, a Qualidade e o Conhecimento como Fatores

$\begin{array}{ll}\text { Estratégicos } & 145\end{array}$

6.5. Perspectivas e Tendências 146

ANEXO A - Relatório Gerencial de Parada Programada $\quad 148$

$\begin{array}{ll}\text { ANEXO B - Cronograma Master da PG2001 } & 150\end{array}$ 
ANEXO C - Organograma Geral da PG2001

ANEXO D - Análise de Risco Potencial (ARP)

ANEXO E - Folha de Resultados Gerais da PG2001

REFERÊNCIAS BIBLIOGRÁFICAS 


\section{LISTA DE FIGURAS}

Figura 2.1 - Demanda mundial de papel e cartão por região (1980-2010) 18

Figura 2.2 - Matriz energética da CRU da VCP_LA 26

Figura 2.3 - Estrutura organizacional da VCP_LA 27

Figura 2.4 - Fluxograma de processo: Recuperação Química VCP_LA 33

Figura 2.5 - Fluxograma de processo: Produção de Celulose VCP_LA 34

Figura 2.6 - Fluxograma de processo: Produção de Papel VCP_LA 35

Figura 3.1 - Ciclo PDCA de controle de processos $\quad 60$

Figura 3.2 - Gestão da manutenção voltada ao processo produtivo 72

$\begin{array}{ll}\text { Figura 3.3 - Gestão compartilhada do processo produtivo } & 73\end{array}$

Figura 4.1 - Detalhe da estrutura organizacional da CRU e Time Manutenção $\quad 88$

Figura 4.2 - Folder de Segurança da Parada Geral 2001

Figura 4.3 - Ordem de Serviço da Parada Geral 2001

Figura 4.4 - Quadro de resultados finais da Parada Geral 2001

Figura 5.1 - Visão geral do ambiente de desenvolvimento da sistemática de manutenção proposta 111

Figura 5.2 - Modelo da sistemática de manutenção proposta. 113

$\begin{array}{ll}\text { Figura } 5.3 \text { - Etapa 1: Estabelecimento da estratégia } & 115\end{array}$

$\begin{array}{ll}\text { Figura } 5.4 \text { - Etapa 2: Planejamento e programação } & 117\end{array}$

$\begin{array}{ll}\text { Figura } 5.5 \text { - Etapa 3: Controle da execução } & 128\end{array}$

$\begin{array}{ll}\text { Figura } 5.6 \text { - Etapa 4: Avaliação e perspectivas } & 135\end{array}$

Figura 6.1 - Gráfico demonstrativo da redução do tempo total de parada de produção de celulose nas últimas Paradas Gerais

Figura 6.2 - Gráfico demonstrativo da redução de horas trabalhadas em Paradas Gerais na CRU

Figura 6.3 - Gráfico demonstrativo da redução do custo total de manutenção por tonelada de celulose produzida na VCP_LA

Figura 6.4 - Gráfico demonstrativo da evolução da produção média de tSS ao ano na caldeira de recuperação 


\section{LISTA DE ABREVIATURAS E SIGLAS}

ABNT - Associação Brasileira de Normas Técnicas

ABTCP - Associação Brasileira Técnica de Celulose e Papel

ADt - em português: Tonelada de Celulose Branqueada (unidade de produção)

APP - Análise de Problema Potencial

ARP - Análise de Risco Potencial

BNDES - Banco Nacional de Desenvolvimento

BRACELPA - Associação Brasileira de Celulose e Papel

CA - Célula de Trabalho Administrativa

CAT - Célula de Apoio Técnico

CCM - Central de Controle de Motores

CCQ - Círculos de Controle da Qualidade

CETESB - Companhia de Tecnologia e Saneamento Básico

$\mathrm{CF}$ - Caldeira de Força

cfm - cubic feet per minuts

CP - Célula de Trabalho Produtiva

CPC - Célula de Produção de Celulose

CPFL - Companhia Paulista de Força e Luz

CPM - Critical Path Method

CPP - Célula de Produção de Papel

CR - Caldeira de Recuperação Química

CRU - Célula de Recuperação e Utilidades

CT - Célula de Trabalho

ECA - Estação de Captação de Água

ECF - Elementar Cloro Free

EM - Engenharia de Manutenção

ETE - Estação de Tratamento de Efluentes

FMEA - em português: Análise de Modo e Efeito da Falha

FTA - em português: Análise de Árvore de Falha 
GEO - Global Excellence in Operations Awards

$\mathrm{h}$ - hora (unidade de tempo)

$\mathrm{Hh}-$ Homem hora

IPT - Instituto de Pesquisas Tecnológicas do Estado de São Paulo

ISO - International Organization for Standardization

JIT - Just in Time

$\mathrm{m}$ - Metro (unidade de medida)

MO - Momentos de Oportunidade Operacional

MP - Máquina de Papel

MWh - Mega-Watt hora (unidade de energia elétrica)

NR - Norma Regulamentadora

OPE - Overall Production Efficiency

OS - Ordem de Serviço

$\mathrm{P}$ - em português: Produtividade

PCC - Precipitado de Carbonato de Cálcio

PCIC - Planejar, Controlar, Informar, Cobrar

PDCA - em português: Planejar, Fazer, Controlar e Agir

PE - Precipitador Eletrostático

PERT - Program Evaluation and Review Technique

PF - Parada Fria

PG - Parada Geral (período anual)

PI - Plant Information

PS - Parada Setorial

PR - Projeto Repensar

Q - em português: Qualidade

QT - Qualidade Total

$\mathrm{R}$ - em português: Confiabilidade

RCFA - em português: Análise de Causas Raízes da Falha

RCM - em português: Manutenção Centrada em Confiabilidade

RPM - Reable Production Management

RS - Rio Grande do Sul (Estado)

SAP - em português: Sistemas, Aplicações e Produções de Processamento de Dados 
SDCA - em português: Padronizar, Fazer, Controlar e Agir

SDCD - Sistema Distribuído de Controle Digital

SENAI - Serviço Nacional de Aprendizagem Industrial

SII - Sistema Integrados de Informações

SIS - Sistema Stripping Integrado

SMI - Specialt Mineral International

SP - São Paulo (Estado)

$\mathrm{t}$ - Tonelada (unidade de medida)

TPM - em português: Manutenção Produtiva Total

TQC - em português: Controle da Qualidade Total

TQM - em português: Gestão da Qualidade Total

TRS - em português: Teor Residual de Enxofre

tSS - Toneladas de Sólidos Secos (unidade de produção)

VAP - Vapor de Alta Pressão

VBP - Vapor de Baixa Pressão

VCP - Grupo Votorantim Celulose e Papel

VCP_LA - Unidade Industrial Luiz Antônio do Grupo VCP

VMP - Vapor de Média Pressão

ZD - Zero Defeitos

4T - Quarto Transformador Principal da VCP_LA

5S - Programa 5S (Seiri, Seiton, Seiso, Seiketsu e Shitsuke)

5W1H - em português: O quê, Quem, Onde, Quando, Por quê e Como. 


\section{RESUMO}

PARRILLA, F. R. (2002). Uma sistemática de manutenção para o gerenciamento e controle de paradas planejadas em processos de produção de celulose e papel. São Carlos, 2002. 179p. Dissertação (Mestrado) - Escola de Engenharia de São Carlos, Universidade de São Paulo.

As paradas planejadas gerais nas indústrias papeleiras, normalmente realizadas anualmente, são fundamentais devido ao processo produtivo e estratégicas para a competitividade no setor. Face à sofisticação dos equipamentos e instalações, denotando intervenções complexas e de grande porte, altos custos e riscos potenciais de acidentes e danos ambientais, procura-se uma caracterização desses eventos como grandes empreendimentos. Esses, fazem parte da estratégia de manutenção definida para a planta fabril, sendo gerenciados pela equipe de manutenção que atua voltada a disponibilidade, confiabilidade, qualidade e produtividade. Neste sentido, este trabalho desenvolve uma sistemática de manutenção para o gerenciamento e controle das paradas planejadas gerais em processos de produção de celulose e papel, com a finalidade de facilitar e promover o sucesso na execução de todas as atividades e etapas envolvidas. Para isso, contextualiza-se o setor e as paradas planejadas; são revisados os principais conceitos, técnicas, práticas e ferramentas características à gestão da manutenção, qualidade e conhecimento; são estudadas abordagens específicas voltadas aos processos de produção contínua; é verificada uma prática empresarial do setor e; finalmente, é proposta uma sistemática fundamentada nestas pesquisas. Como principais benefícios observam-se: a sinergia entre as equipes de manutenção e operação; a valorização da manutenção na gestão do processo produtivo; a competitividade do negócio; a otimização dos recursos e as alavancagens de produtividade.

Palavras-chave: manutenção; gerenciamento de manutenção; paradas planejadas; celulose - papel. 


\section{$\underline{\text { ABSTRACT }}$}

PARRILLA, F. R. (2002). Systematic planning for the management and control of planned stops within the cellulose pulp and paper production processes. São Carlos, 2002. 179p. Master Degree Thesis presentation - São Carlos Engineering School, University of São Paulo.

The general planned stops within the paper industries, once in the year as a rule, are due to the productive process and competitiveness strategies in that business sector. Current sofistified equipments and facilities call for complex and significant interventions. Because high costs involved and potential risks of both accidents and environmental nature damage, those events are characterized as important projects. They are part of the strategy defined for the manufacturing plant, thus being managed by the maintenance team focusing availability, reliability, quality and productivity. In view of such scenario, this paper develops a maintenance system addressing the management and control of planned stops within the cellulose pulp and paper production processes. The scope is to facilitate and promote the success when carrying out all the activities involved. Therefore, the context of the sector and planned stops is discussed; the main concepts, techniques, practices and tools specific to the management of maintenance, quality and knowledge are reviewed; approaches specific to the continuous production processes are studied; business practices within the sector are analyzed, and, finally, a systemic approach proposal is made grounded on the preceding research. The most important benefits observed were: the achievement of synergy among the maintenance and production teams; the true understanding of the maintenance value in the productive process; the business competitiveness; resources optimization as well as productivity boosting.

Key words: maintenance; management maintenance; planned stops; cellulose pulp paper 


\section{CAPITULO 01}

\section{INTRODUÇÃO}

\subsection{Visão Geral do Setor Papeleiro}

Desde sua invenção a quase dois mil anos atrás o processo de fabricação de celulose e papel é o mesmo, em essência. Porém, muita tecnologia foi agregada durante sua evolução de um processo artesanal para um de produção contínua, fazendo com que o "papel” se tornasse um produto fundamental na história da escrita (IPT-SENAI, 1988).

Atualmente, o setor papeleiro encontra-se em constante ascensão, apresentando uma taxa de crescimento a cerca de $3 \%$ ao ano no mundo, vislumbrada num horizonte de 10 anos. Nas regiões subdesenvolvidas e tropicais, com o destaque para o Brasil, observam-se índices em torno de 5\% (SAVASTANO, 2001).

No Brasil, a indústria papeleira iniciou suas operações ao final da década de 50, com a introdução do eucalipto como matéria-prima na produção da celulose. Em meados da década de 60, uma nova mentalidade empresarial e diversos mecanismos de suporte à iniciativa privada como os incentivos fiscais e o Programa Nacional de Celulose e Papel alavancaram esse setor, fazendo com que empresas nacionais surgissem e investissem nesse ramo (BOARETO, 1985; CAPO, 1999).

No período referente ao ano 2000, foi registrada uma produção de 7 milhões de toneladas de papel no Brasil, o que representou 2,35\% da produção mundial e $48 \%$ em relação a da América Latina. Em âmbito nacional, o setor papeleiro contribuiu com um superávit US\$1,847 bilhão, quase o dobro do registrado no período anterior e que garantiu ao setor o segundo lugar no ranking de geradores de saldos comerciais (SAVASTANO, 2000).

Face a um mercado globalizado, aspectos como a alta tecnologia e produtividade tornaram-se fundamentais a sobrevivência das empresas desse setor. $\mathrm{O}$ 
processo de produção é amplamente automatizado e constituído de milhares de equipamentos e instalações, onde a confiabilidade da planta fabril é essencial para a segurança operacional e o controle do meio ambiente, devido as características e condições de operação.

Além disso, em virtude da evolução e equalização tecnológica dos processos de fabricação de celulose e papel em nível mundial, e com a busca incessante da máxima disponibilidade e confiabilidade das plantas foram necessárias profundas mudanças culturais e organizacionais, além da aplicação de técnicas e ferramentas específicas em áreas estratégicas como a manutenção e a qualidade, visando sempre o desenvolvimento e capacitação do homem, certamente o maior diferencial apontado na atualidade para o sucesso das empresas no setor.

Nesse contexto, encontram-se várias empresas e companhias nacionais e multinacionais que atuam no Brasil. Entre elas, pode-se destacar o Grupo Votorantim Celulose e Papel (VCP), constituído por quatro unidades industriais e duas florestais, sendo a Unidade Industrial Luiz Antônio (VCP_LA) objeto de referência e pesquisa deste trabalho.

\subsection{A Função Manutenção nesse Ambiente}

Face as características tecnológicas do processo de fabricação de celulose e papel, os principais desafios buscados pelas empresas desse setor referem-se à alavancagem na produtividade, na qualidade do produto, na confiabilidade e segurança operacional e, finalmente, na disponibilidade do processo.

Com isso, fizeram-se imprescindíveis mudanças culturais e organizacionais nas indústrias papeleiras, pois as pessoas passaram a ser fundamentais, e a gestão do conhecimento e da cultura da organização, fatores indispensáveis.

Destacam-se também, a "política de manutenção da planta fabril" e a "qualidade do processo e do produto", durante a evolução desse segmento, onde os sistemas informatizados e as novas práticas, técnicas e ferramentas de análise e gestão foram fatores chaves de suporte na difusão desses conceitos.

Nesse contexto, a função manutenção tornou-se estratégica para o 
gerenciamento do processo produtivo de forma integrada. A partir de meados da década de 70 a manutenção, que vinha numa evolução crescente desde a Segunda Guerra Mundial, foi colocada como uma das principais funções dentro das indústrias, fazendo com que novas responsabilidades e formas de pensar e agir fossem introduzidas no dia-a-dia do homem de manutenção (PINTO \& XAVIER, 1999).

Como escreve TAVARES et al. (1999:11):

“...já em 1975, a Organização das Nações Unidas caracterizava a atividade fim de qualquer entidade organizada como: Produção = Operação + Manutenção".

Neste cenário, caracterizado pela queda de paradigmas referentes a forma de focar e gerenciar a manutenção nas empresas, vários tipos e práticas de manutenção (corretiva, preventiva, preditiva e detectiva) foram desenvolvidos e estudados, muitas ferramentas como Análise de Falhas (FMEA e RCFA), Análise de Riscos (ARP), Análise de Problemas Potenciais (APP) e Análise de Árvore de Falhas (FTA) foram colocadas à disposição. Técnicas de Manutenção Centrada em Confiabilidade $(R C M)$ foram implantadas, grupos de Engenharia de Manutenção criados, entre outras tantas iniciativas.

Além disso, para a aplicação de todas essas ferramentas e técnicas com sucesso fez-se necessária uma gestão mais efetiva e descentralizada das equipes de manutenção, alicerçada na implementação de planos de manutenção bem definidos para cada equipamento e instalação, e na divisão das responsabilidades pela produtividade e competitividade entre todos os envolvidos no processo produtivo. NAGAO (1998), sintetiza a manutenção na atualidade como uma função estratégica que busca uma maior confiabilidade e disponibilidade das instalações através da diminuição de quebras e falhas nos equipamentos e sistemas, otimizando o uso dos recursos disponíveis.

No início da década de 80 , os conceitos de gestão voltados para a qualidade surgiram em âmbito mundial com idéias que se somaram às necessidades da "função manutenção". Filosofias como as de Qualidade Total (TQM e TQC), e programas como $5 S$ e Manutenção Produtiva Total (TPM) viabilizaram uma atuação da manutenção de melhor qualidade e o compartilhamento das responsabilidades em "manter" junto com a equipe operacional, bem como a implementação de uma cultura organizacional voltada à mudança e a capacitação do homem (KRÖNER, 
1999; ABRAMAN, 1999; TAVARES, 1999).

O surgimento de grupos como manutenção autônoma e manutenção planejada, a utilização de técnicas orientadas pelo giro do Ciclo PDCA (Plan - Do Check - Action) e SDCA (Standard), bem como a implementação de programas para o estímulo do trabalho em grupo e o desenvolvimento da ética social e profissional do homem, defendidos por filosofias japonesas como Kaizen, trouxeram vários ganhos às pessoas como: polivalência, comprometimento, sinergia e flexibilidade.

A avassaladora onda da nova visão da função qualidade no mundo também trouxe a necessidade de abordagens técnicas que quantificassem e normatizassem, em nível global, as características de produção através de padrões uniformes de mercado a serem seguidos.

A aplicação de ferramentas e técnicas da manutenção aliadas aos conceitos e programas da qualidade proporcionam a implementação de uma gestão da produção adequada ao desenvolvimento de uma forte "política de manutenção" que, em processos de produção contínua como do setor papeleiro, deve atuar voltada para uma estratégia de atuação na planta fabril que visa:

- Monitoramento contínuo dos equipamentos e sistemas

- Intervenções em Momentos de Oportunidade (MO)

- Paradas Setoriais (PS’s) - Intervenções planejadas periódicas

- Paradas Gerais (PG's) - Intervenções planejadas anuais

Finalmente, deve-se observar que todas essas formas de atuação da equipe de manutenção são voltadas à antecipação dos problemas e falhas, e a eliminação das paradas imprevistas pois, na visão atual, segundo PINTO \& XAVIER (1999) a manutenção deve existir para que não haja manutenção, visão compartilhada pelo setor papeleiro.

\subsection{As Paradas Planejadas}

Atualmente, a atuação somente de forma planejada, com ações amplamente analisadas, detalhadas e executadas em momentos pré-definidos, principalmente quando envolvem reduções ou paralisações da produção, são as 
formas de intervenção mais adequadas e utilizadas nas plantas de fabricação de celulose e papel, devido principalmente à necessidade de alta confiabilidade no processo e ao desgaste excessivo dos equipamentos.

Com isso, intervenções apenas em paradas planejadas são as diretrizes básicas para uma empresa que deseja competir neste setor, caracterizando assim as PS's e as PG's como eventos estratégicos que devem ser gerenciados com todos os cuidados necessários a grandes empreendimentos.

No presente trabalho, o enfoque principal serão os eventos de PG, normalmente realizadas em periodicidade anual que, devido às suas características estratégicas e críticas, requerem cuidados especiais no planejamento e execução.

Nesse contexto, grupos multidisciplinares como o de planejamento e o de engenharia de manutenção freqüentemente têm como parte de suas atribuições a responsabilidade da gestão de paradas, centralizando as informações, envolvendo as pessoas necessárias, provendo os recursos adequados, e acompanhando os desvios e os indicadores de desempenho junto aos gerentes.

Contudo, para uma gestão efetiva da PG é fundamental um ambiente organizacional que promova o contínuo desenvolvimento de profissionais pró-ativos, flexíveis às mudanças e que tenham comprometimento, bem como uma visão voltada ao trabalho em equipe, divisão de responsabilidades, entre outras características.

\subsubsection{Uma necessidade do processo de fabricação}

Como em todo processo de produção contínua, inclusive na fabricação de celulose e papel o ritmo é acelerado, intenso e desgastante, tanto para as pessoas envolvidas, como principalmente para os equipamentos e instalações, haja vista que a maioria desses equipamentos trabalham 24 horas por dia.

Com isso, as paradas planejadas de equipamentos específicos, sistemas e sub-processos são fundamentais e indispensáveis, permitindo a execução de atividades operacionais, intervenções e manutenções de rotina que só podem ser realizadas com os sistemas e equipamentos fora de operação.

Outro fator importante vem das características específicas desse 
processo, no qual os subprodutos e demais substâncias envolvidas apresentam um elevado grau de aderência às tubulações, equipamentos e tanques, como resultado de reações químicas. Essa tendência para a ocorrência de incrustações tornam as intervenções periódicas necessárias para limpezas, reparos, inspeções e testes.

Entretanto, além das necessidades advindas do desgaste dos equipamentos diretamente envolvidos e do processo em si, há que se considerar também parâmetros legais para alguns equipamentos especiais. É o caso dos "vasos de pressão" e "caldeiras", que devem satisfazer Normas Regulamentadoras (NR's) de segurança para seu funcionamento, estabelecidas pela Associação Brasileira de Normas Técnicas (ABNT), sendo inspecionados e testados periodicamente por empresas autorizadas que verificam o atendimento destas normas.

Como exemplos, destacam-se num processo de fabricação de celulose e papel através da polpação Kraft: Caldeiras de Recuperação Química (CR) e de Força (CF), Digestores, Tanques Acumuladores e Distribuidores de Vapor, além dos vários sistemas de segurança que os compõem.

Quando têm-se uma parada planejada completa da planta, com o resfriamento, abertura, drenagem e limpeza de tanques, dutos e tubulações caracteriza-se uma PG, que envolve a consideração de quatro fatores determinantes:

\section{1) Reparos preventivos e corretivos - manutenções de rotina}

Aqui destacam-se os reparos ou descartes programados nos equipamentos de possível acompanhamento quanto à sua vida útil e padrões de desempenho (manutenção preditiva). Nesta situação enquadram-se bombas, motores, redutores, ventiladores e sopradores, cujas falhas tendem a se apresentar de acordo à um padrão definido, seja pelo fim da vida útil de algum componente ou desgastes monitoráveis devido sua interação direta com o processo.

\section{2) Melhorias, modificações e novas instalações}

Aqui quatro atividades são freqüentemente realizadas nas empresas do setor papeleiro, principalmente quando se tem uma gestão compartilhada do processo produtivo entre as equipes de manutenção e operação.

A primeira é a modificação de projeto, que tem o objetivo de ampliar a 
vida útil de um equipamento ou reduzir o impacto das conseqüências de suas falhas.

A segunda é a melhoria de processo, que visa ganhos de produtividade ou redução de perdas através de pequenas modificações na planta ou alterações em linhas e arranjos físicos.

A terceira é caracterizada pela instalação de novos equipamentos, necessários para ampliações na capacidade produtiva ou adequações em termos de tecnologia aplicada, e envolvem grandes investimentos e são definidas junto à alta gerência da empresa.

Por fim, destacam-se as melhorias de manutenção, cuja finalidade é aumentar a manutenabilidade de um equipamento, proporcionando assim condições adequadas para intervenções futuras.

\section{3) Inspeções, testes e limpezas operacionais}

A limpeza de estruturas, linhas, tanques e equipamentos de transferência de produtos e subprodutos, seguidas de inspeções e testes são necessários e indispensáveis e quase sempre representam os "caminhos críticos" das Paradas.

Normalmente, para essas limpezas são utilizados jatos de alta pressão de água, ar ou areia, sendo realizadas por empresas especializadas contratadas para esse fim, e que trabalham com o acompanhamento e supervisão da contratante.

Após a limpeza são realizadas inspeções e testes em cada equipamento e instalação, de forma criteriosa e sistemática, a fim de identificar anormalidades nas características e padrões estabelecidos como ideais. Essas inspeções também são caracterizadas como atividades de engenharia de manutenção.

É importante ressaltar que esse tipo de atividade deve ser realizada em conjunto entre as equipes de operação e de manutenção, pois a primeira contribuirá com a identificação de locais e equipamentos que estão demonstrando sinais de deterioração e perda de eficiência, enquanto a segunda tem todos os históricos e criticidades necessárias para determinar as regiões e equipamentos com maiores probabilidades de falhas.

\section{4) Adequação às Normas Regulamentadoras de segurança (NR)}

Vários equipamentos e sistemas trabalham em condições extremas 
durante todo o tempo. Além disso, alguns estão expostos a temperaturas e pressões elevadíssimas, representando um perigo constante para o ambiente de trabalho.

No processo aqui abordado, os "vasos de pressão" e "caldeiras" merecem uma atenção diferenciada e cuidados especiais, além de serem acompanhados e supervisionados por empresas autorizadas no que diz respeito a verificação de seus padrões e características específicas de desgaste.

Com base em normas e padrões legais são realizados testes e inspeções periódicas nesses equipamentos, definindo-se as autorizações para sua operação. Como exemplo, tem-se a Norma ABNT (1998) NR-13, específica para caldeiras e vasos de pressão.

\subsubsection{O momento da equipe de manutenção}

Durante o funcionamento de uma planta fabril, todas as ações que envolvem a operação do processo produtivo são de responsabilidade e supervisão da equipe operacional, salvo em algumas situações onde intervenções são indispensáveis e paradas ou reduções são requeridas pela equipe de manutenção. Assim, a equipe de manutenção apoia a equipe de operação executando tarefas preventivas, preditivas e detectivas, atendendo solicitações quando anormalidades são observadas ou realizando atividades de engenharia de manutenção.

No entanto, durante uma PG as posições se invertem, pois agora a atuação da Manutenção é direta, e a planta está sob seus cuidados. Com isso, dependem desta equipe algumas atividades básicas, como:

- a contratação e disponibilização dos recursos necessários para as atividades e intervenções: mão-de-obra, serviços, materiais etc.;

- a coordenação e o acompanhamento de todas as ações durante o evento: verificando o andamento de todos os trabalhos quanto ao cumprimento do prazo previsto para sua execução, custos, qualidade das intervenções etc.;

- a monitoração contínua de todas as metas gerenciais e desafios: fatores de risco identificados, planos, desempenhos, falhas etc.. 
Entretanto, para que essas atividades sejam realizadas a contento, tornase necessário um forte trabalho de planejamento, preparação, controle da execução e avaliação, haja vista a importância das intervenções a serem realizadas e o caráter estratégico que tem a PG nas indústrias do setor papeleiro.

Além disso, deve-se notar que toda e qualquer atividade e intervenção de PG freqüentemente envolve várias equipes e setores, como: manutenção, engenharia, segurança, operação, suprimentos, serviços de apoio, entre outros. Também, como as plantas são interdependentes, compondo subprocessos, normalmente têm-se paradas inter-relacionadas, tornando o ajuste fino entre os planos indispensável.

Dessa forma, é na equipe de manutenção que devem estar centralizadas todas as informações pertinentes ao evento, tanto durante os preparativos como no momento da execução. Todas as decisões são discutidas e definidas junto a essa equipe, que deve ter uma visão global e sistêmica da PG.

\subsection{Caracterização do Problema}

Num enfoque global do evento, segundo STONNER (2001), as paradas planejadas (PS's ou PG's) em uma unidade de processo são tidas como grandes "empreendimentos", os quais são caracterizados da seguinte forma:

- Finitos: data de início ou término definidos ou previstos.

- Complexos: repletos de interfaces entre as diferentes especialidades envolvidas.

- Homogêneos: pode ser organizado de forma seqüencial, respeitadas as interdependências entre fases e tarefas, e esta seqüência pode ser continuamente otimizada.

- Não repetitivos: não há dois projetos iguais.

Também, complementa o autor, o empreendimento como um todo, tem um ciclo de vida definido em quatro etapas básicas, que podem ser superpostas: concepção, planejamento, implementação e finalização. Para os eventos de PG, deseja-se uma abordagem bastante similar. 
Essas paradas em indústrias papeleiras são constituídas por inúmeros detalhes que devem ser continuamente monitorados, pois podem configurar fatores de risco em potencial como, por exemplo:

- a contratação dos recursos de mão-de-obra e de apoio;

- a gestão das atividades de centenas de pessoas contratadas;

- as interfaces dos diversos setores envolvidos;

- o planejamento de todas as atividades e intervenções;

- a elaboração dos cronogramas e planos;

- a gestão da logística do evento;

- o acompanhamento do desempenho na execução das atividades;

- a gestão dos recursos financeiros disponíveis;

- os aspectos voltados à segurança e meio ambiente;

- a realização de reuniões para os preparativos da Parada;

- a atribuição das responsabilidades a todos os envolvidos e a formação de grupos de trabalho;

- registro de todos os fatores representativos que ocorrerem durante a realização dos serviços, como desvios, falhas, acidentes, ganhos etc.;

- avaliação do desempenho da Parada de forma global etc..

Além disso, deve-se lembrar que nesses eventos alguns milhões de reais são gastos em poucos dias, o que denota a importância da disseminação de uma visão estratégica e sistêmica para todos os envolvidos. Uma equipe de manutenção qualificada (em todos os níveis), práticas de gestão voltadas a qualidade, confiabilidade e produtividade, o desenvolvimento de procedimentos padronizados e sistemáticos, o suporte de sistemas informatizados e, a formação de uma cultura próativa nas pessoas envolvidas diretamente são alguns dos aspectos essenciais.

Ainda, como principais exigências que se destacam face ao desenvolvimento da PG, têm-se:

- visão global e sistêmica do empreendimento PG;

- sistematização e padronização das etapas e atividades;

- alto grau de disciplina durante o planejamento e execução;

- sinergia entre as equipes de manutenção e operação; 
- organização, comprometimento e capacitação dos envolvidos;

- padrão único de qualidade em todos os serviços realizados e recursos utilizados;

- acompanhamento e controle estatístico das atividades e intervenções;

- utilização de técnicas, práticas e ferramentas adequadas de análise;

- busca da melhoria contínua.

Entretanto, métodos para gerenciar adequadamente a PG não estão bem definidos na literatura até hoje. Poucos são os trabalhos que discutem especificamente esse assunto e que comentam sobre um ambiente que proporcione a aplicação de uma sistemática ou método efetivo de gerenciamento, fazendo com que os profissionais das empresas do setor atuem normalmente por instinto e experiência.

Nesse contexto, seguindo o enfoque proposto surgem duas questões:

1. Como identificar, padronizar, tratar e controlar todos os detalhes que envolvem uma parada planejada geral em processos de fabricação de celulose e papel?

2. Quais características de gestão, conceitos, técnicas e ferramentas são necessárias para um gerenciamento efetivo e pró-ativo deste empreendimento?

\subsection{Objetivo}

Face a problemática apresentada, o objetivo deste trabalho é o desenvolvimento de uma sistemática de manutenção para o gerenciamento e controle de paradas planejadas gerais em processos de produção de celulose e papel. Essa sistemática foi concebida a partir da análise de modelos de gestão de manutenção disponíveis na literatura, e da verificação da prática empresarial, visando-se a reunião e a organização desse conhecimento.

Para tanto, busca-se definir formas adequadas para a identificação clara e otimização de suas etapas, a partir de uma visão gerencial voltada para a melhoria contínua, à redução de tempo e custo, ao mínimo de indisponibilidade e retrabalhos, e a aspectos de segurança e meio ambiente. 


\subsection{Desenvolvimento e Estruturação da Dissertação}

De forma a atingir o objetivo proposto, buscando sustentação ao assunto e ambiente de desenvolvimento, foram realizados dois tipos de pesquisa:

- Pesquisa bibliográfica - trabalhos específicos relacionados ao tema e as variáveis envolvidas;

- Pesquisa de campo - realizada junto a uma empresa do setor papeleiro.

Quanto à metodologia, foram aplicadas a "exploratória" e a "descritiva". Exploratória pelo caráter investigativo e orientativo, referente ao tema e ao desenvolvimento do próprio trabalho, e descritiva pela observação dos fatos de forma a caracterizá-los e organizá-los para aplicações práticas (ANDRADE, 1999).

Partindo-se da necessidade fundamentada na problemática apresentada, é desenvolvida uma sistemática de manutenção para o gerenciamento e controle de paradas planejadas gerais com a caracterização desses eventos como empreendimentos de grande porte.

Visando obter bases concretas para isso, no decorrer do presente trabalho serão verificadas e estudadas algumas abordagens voltadas ao gerenciamento e controle de paradas planejadas em processos de produção contínua, desenvolvidas a partir de experiências históricas das empresas, benchmarking das melhores práticas e análise desses eventos por consultorias e auditorias especializadas.

Também, será verificado um evento de PG na prática, bem como apresentados conceitos, práticas, técnicas e ferramentas úteis a difusão de um padrão de atuação e comportamento voltado à qualidade e a manutenção de excelência.

Por fim, são caracterizados todos os aspectos relevantes em relação a funcionalidade da sistemática proposta, ao aumento do desempenho da manutenção e aos benefícios para o negócio, face a competitividade de mercado.

Nesse contexto, esta dissertação está estruturada em seis capítulos, com a seguinte descrição básica:

O capítulo 1 apresenta o contexto do setor empresarial enfocado por este trabalho e a evolução e característica da manutenção neste ambiente, delimita o assunto 
abordado, caracteriza o problema em foco, estabelece o objetivo da dissertação e apresenta a forma de desenvolvimento e estruturação desta.

No capítulo 2 é dada uma visão geral do setor papeleiro, das características e tendências de mercado, tanto em âmbito nacional como mundial, bem como detalhado o processo de fabricação de celulose e papel desenvolvido na VCP_LA.

O capítulo 3 é constituído de uma revisão bibliográfica dos principais conceitos, práticas, técnicas e ferramentas aplicadas à gestão da manutenção e à qualidade total; dos principais sistemas informatizados de apoio a manutenção; e de algumas considerações sobre os aspectos humanos e culturais envolvidos.

No capítulo 4 são analisadas algumas abordagens disponíveis e características específicas ao tema, e é apresentada uma verificação na prática de um evento de PG realizado na VCP_LA. As particularidades do ambiente de verificação, bem como os resultados obtidos no evento também são apresentados e discutidos, a fim de fornecer subsídios para a proposição da sistemática de gerenciamento e controle.

No capítulo 5 é desenvolvida a sistemática de manutenção para o gerenciamento e controle de eventos de PG em processos de produção de celulose e papel, que é o objetivo principal dessa dissertação.

No capítulo 6, finalmente, são feitas considerações e análises sobre a sistemática proposta, da gestão da manutenção e dos impactos para o negócio; além da elucidação de perspectivas, tendências e sugestões para pesquisas futuras. 


\section{CAPITULO 02}

\section{O MERCADO E O PROCESSO DE FABRICAÇÃO DE CELULOSE E PAPEL}

\subsection{Origem, Evolução e Cenário Atual do Setor Papeleiro no Mundo}

A maioria dos historiadores concordam que a primeira folha de papel foi produzida na China há quase dois mil anos atrás, mais especificamente em 105 d.C., quando através de uma experiência caseira um homem chamado Ts'ai Lum obteve uma mistura pastosa misturando em uma tina d'água cascas de árvores, pedaços de bambu, roupas, redes de pesca usadas e cal. Basicamente, ele ferveu durante algum tempo essa mistura, coou e amassou a pasta resultante e a esticou ao sol para secar sobre uma peneira (IPT-SENAI, 1988).

Diante dessa nova descoberta, os chineses procuraram dificultar o crescimento e a difusão dessa nova cultura pelo mundo e, segundo dados do IPTSENAI (v.1, 1988), conseguiram manter esse segredo sob seus domínios até o final do século VI, quando os árabes quebraram seu monopólio. A partir deste momento, o processo de fabricação do papel começou a ser difundido pela Europa e esse novo suporte para a escrita substituiu progressivamente o uso da seda no mundo.

Como inicialmente as matérias-primas naturais para a fabricação do papel eram as árvores coníferas que existiam em abundância na Europa, nos países escandinavos e na América do Norte, regiões caracterizadas por uma disponibilidade ilimitada deste tipo de vegetação, naquela época, aliada a um avançado nível técnico cultural, os países lá localizados destacaram-se como os primeiros grandes produtores desse artefato. Com isso, os Estados Unidos, o Canadá, a União Soviética, a Suécia, a Finlândia e a Alemanha foram os pioneiros nesse novo e promissor setor da manufatura. Como exemplo da matéria-prima utilizada nestas regiões, tem-se os pinus, que caracterizam-se por apresentarem fibras longas, ideais para fabricação de 
papéis resistentes, como o papelão.

No fim do século XVI, os holandeses criaram a primeira máquina manual de produção de papel que permitia desfazer trapos e, posteriormente, diversas espécies vegetais fibrosas, em um vaso de forma oval com um rolo central rotativo. Com a revolução desse rolo, a mistura era comprimida formando folhas úmidas na área inferior do vaso, que eram depois secadas. Essa máquina ficou conhecida como "Holandesa", e chegou até nossos dias sem que aperfeiçoamentos significativos modificassem sua idéia básica (IPT-SENAI, 1988).

O desenvolvimento e a difusão dessa forma de fabricação e a Revolução Industrial em meados do século XVIII fizeram com que o consumo mundial de papel e a capacidade produtiva aumentassem representativamente. Neste período, os recursos florestais dos tradicionais produtores de celulose, a base de coníferas e demais vegetações fibrosas regionais, alcançavam o máximo de seu aproveitamento, promovendo assim a necessidade da procura por outras matérias-primas que suprissem as crescentes necessidades desse mercado. Com isso, registrou-se o aumento dos estudos e experiências com várias matérias-primas fibrosas, destacando-se e alternando-se por períodos várias culturas, como: gramas, palhas, bambu, bagaço de cana e o sisal, entre outros.

Como decorrência, foi intensificado o desenvolvimento das técnicas para o cultivo das matérias-primas necessárias na fabricação do papel, que alavancaram o aumento da capacidade produtiva e a difusão dessa manufatura pelo mundo. Com uma demanda crescente para esse novo produto, à produtividade, que era o único foco desse setor até o século XIX, foi acrescida a preocupação também para a "qualidade" do produto final.

Dessa forma, características como brancura, espessura, lisura e resistência da folha de papel começaram a ser estudadas e perseguidas nos processos de produção, sendo que esses passaram a configurar a qualidade e as características de mercado do papel.

O século XIX também foi marcado pela busca de um método viável para o branqueamento do papel, que só era obtido até então a partir de trapos brancos, sendo que somente no final do século, com a descoberta do cloro e a produção de pó alvejante foi possível ampliar o círculo das matérias-primas possíveis para essa 
manufatura. Entretanto, o efeito deteriorador exercido por esses agentes motivou estudos sistemáticos desse processo (IPT-SENAI, 1988).

Foi nessa evolução que se verificou, no início do século $\mathrm{XX}$, a possibilidade da utilização da madeira de árvores folhosas como, por exemplo, o eucalipto. Esta espécie de madeira é composta de fibras curtas, o que proporciona a fabricação de um papel menos resistente, entretanto mais adequado e de melhor qualidade para escrita e impressão (BOARETO, 1985).

Durante a década de 50 um brasileiro, Max Feffer, descendente de ucrânianos liderou um grupo de cientistas na pesquisa de uma nova tecnologia que revolucionou a fabricação de papel no mundo, caracterizada pelo desenvolvimento da extração de celulose do eucalipto, cuja a produção industrial teve início de forma pioneira em 1956 no Brasil (SAVASTANO, 2000).

Nesse contexto, com a consolidação da utilização da madeira de fibras curtas na produção da celulose, iniciou-se uma tendência de maior distribuição da indústria papeleira no mundo. Segundo BOARETO (1985), já em meados da década de 80 , dentre as diversas matérias primas vegetais utilizadas para a produção de celulose, a madeira representa cerca de $90 \%$ do total consumido no mundo.

Paralelamente a introdução do eucalipto na fabricação do papel, aspectos como prensagem, secagem e colagem da folha de papel foram pesquisadas e introduzidas na máquina desenvolvida pelos irmãos Fourdrinier, sendo introduzido nela um cilindro alisador, capaz de fabricar papel de alto brilho em uma das faces. Além disso, neste período iniciaram-se os estudos e desenvolvimentos de processos químicos de polpação, que emergiram de forma variada voltados a utilização dos recursos naturais disponíveis regionalmente (IPT-SENAI, 1988).

Atualmente, chegou-se ao papel alcalino, no qual obtém-se uma brancura quase total aliada a um mínimo de deterioração através do tempo, garantindo assim uma folha de papel de altíssima qualidade.

No inicio do século XX, segundo IPT-SENAI (v.1, 1988:5):

“...observa-se, ao lado do surgimento de novos materiais, a concepção e a criação de equipamentos, cuja a ação substituía, com vantagem, a mão-de-obra de oferta limitada. Entre esses equipamentos pode-se destacar a mesa formadora dos irmãos Fourdrinier; (...) As numerosas e pequenas usinas produtoras, de capacidade muito restrita, desapareciam em boa parte, cedendo 
seu lugar a unidades maiores que, usando equipamento recémelaborado, apresentavam volumes bem maiores de produção."

Outra característica importante do setor papeleiro é a crescente constituição de unidades fabris de grande porte, em detrimento aos pequenos moinhos comuns no passado. Isso deve-se a necessidade de alta capacidade produtiva e tecnologias inovadoras, que denotam altos investimentos e estreitas ligações com o mercado externo. Segundo IPT-SENAI (v.1, 1988:5):

"A diversificação dos produtos, dos processos e da maquinaria envolvida não aumentou o número de moinhos; pelo contrário, considerações econômicas, organizacionais e operacionais levaram a níveis mais elevados de concentração e integração, tendência atualmente em plena evolução."

Muita tecnologia foi agregada à fabricação do papel desde sua invenção, quando era um processo artesanal. Entretanto, esse processo de fabricação mantém suas características básicas até hoje, sendo que os principais diferenciais buscados pelas empresas desse setor atualmente são referentes a produtividade, qualidade e confiabilidade operacional. Produzir ininterruptamente, no máximo de sua capacidade e com qualidade garante a competitividade e o sucesso no mercado atual.

\section{O cenário mundial atual}

Atualmente, as matérias-primas mais utilizadas na produção de papel são os "pinus" e os "eucaliptos", sendo que estes dividem as características mundiais da industria papeleira. Acima da Linha do Equador têm-se processos de produção baseados na polpação através das fibras longas, obtidas com o processamento de Pinos cultivados em regiões frias. Já no hemisfério sul, os processos de fabricação são adequados a polpação a partir das fibras curtas, obtidas com os Eucaliptos cultivados nas regiões tropicais.

Segundo CAPO (2000), empresa finlandesa de consultoria conceituada mundialmente no setor, o perfil global da indústria de papel e celulose apresenta um índice de crescimento anual em torno de 3\%, característica que deve se manter nos próximos 10 anos. Além disso, projeções demonstram que as regiões 
subdesenvolvidas como a Ásia e a América Latina devem ter um crescimento mais acentuado, na ordem de $5 \%$ ao ano, como pode ser verificado no quadro abaixo:

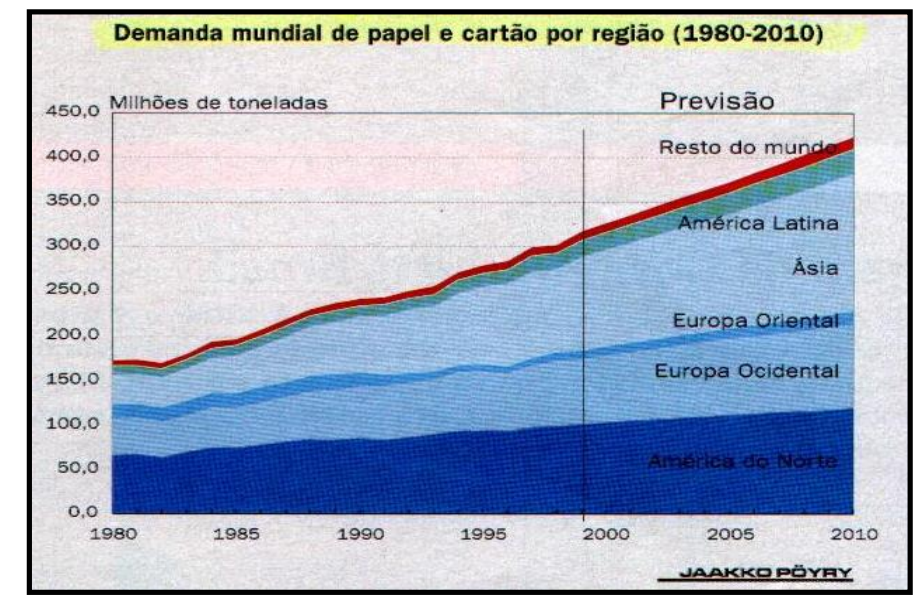

Figura 2.1 - Demanda mundial de papel e cartão por região (1980-2010), Revista CAPO (2000:55). Edição de Dezembro.

Também, nota-se no setor papeleiro uma indústria com características regionais, onde a produção e o consumo são mal distribuídos. Ainda, de acordo com estudos da JAAKKO PÖYRY (2000), do volume atual aproximado de produção de 350 milhões de toneladas de papel no mundo, a média de consumo mundial de papel está em $51 \mathrm{~kg} / \mathrm{hab} / \mathrm{ano}$, sendo que a intensa disparidade entre este valor médio pode ser comprovada entre o Brasil, com 41kf/hab/ano, e Estados Unidos, onde o índice chega a $380 \mathrm{~kg} / \mathrm{hab} / \mathrm{ano}$.

Quanto aos grandes produtores mundiais, pesquisas de mercado apontam para uma tendência de aumento das fusões e aquisições no setor, customização para clientes, redução de custos do processo, terceirização e integração, maior mobilidade e flexibilidade dos profissionais, bem como a consolidação de companhias mais versáteis para atuar no mercado moderno (CAPO, 2000). Atualmente, a International Paper, uma das maiores empresas do setor no mundo, produz cerca de 15 milhões de toneladas de papel ao ano, o que representa $5 \%$ da produção mundial, o equivalente a quase toda a produção da América Latina.

No âmbito tecnológico de produção CAPO (2000), consultor da Associação Brasileira Técnica de Celulose e Papel (ABTCP), não visualiza grandes rupturas no momento e acredita que os investimentos em tecnologia continuarão focados na área florestal e no desenvolvimento de alguns produtos diferenciados, o 
que não deve ocorrer com a celulose, pelo menos nos próximos 10 anos.

Apesar da acentuada alavancagem das novas formas de comunicação digitais, destacando-se ferramentas como a Internet e os correios eletrônicos, o setor papeleiro está atualmente em crescimento. Segundo pesquisas de estudiosos do setor, isto deve-se a quatro propriedades básicas, as quais ainda garantem a preferência do cliente final pela forma de comunicação convencional, sendo elas: facilidade de manuseio e uso; garantia da não perda da informação, como, por exemplo, ocorre com frequiência no meio virtual; e acessibilidade, pois é fácil e rápido consultar informações e conhecimento (CAPO, 2000).

\subsection{A Indústria Papeleira no Brasil}

Segundo BOARETO (1985), em meados do século XX, com a introdução do eucalipto como insumo principal na produção de celulose nas regiões tropicais, o Brasil surge no setor papeleiro impulsionado por vários fatores:

- o emergente desenvolvimento tecnológico do emprego da madeira do eucalipto no processo de fabricação da celulose, principalmente devido às características diferenciadas apresentadas pelos papéis de fibras curtas;

- as excelentes condições climáticas de seu território, que permitem o rápido desenvolvimento do eucalipto;

- uma nova mentalidade empresarial que passou a imperar no País a partir de meados da década de 60;

- e, também, devido ao apoio governamental através de diversos mecanismos de suporte à iniciativa privada, tais como os incentivos fiscais e o Programa Nacional de Celulose e Papel.

Além disso, desde o início da década de 50, as pesquisas realizadas por Max Feffer, na época vice-presidente da Companhia Suzano de Papel, uma das primeiras papeleiras nacionais, realizando experiências com a utilização do eucalipto para extração da celulose na Universidade da Florida, Estados Unidos, resultaram em uma nova técnica de produção de celulose e contribuíram para uma gradativa 
ascensão da indústria papeleira no País.

É importante ainda salientar que o Brasil, segundo (SAVASTANO, 2000), foi pioneiro na utilização do eucalipto na fabricação da celulose em âmbito mundial em 1956. Isto deveu-se principalmente à apreensão das empresas estrangeiras quanto à utilização da matéria-prima de fibra curta na fabricação da celulose, que não era comum e estava em fase de estudos, e às características do desenvolvimento desse setor no hemisfério norte, haja vista que até então a indústria papeleira era voltada ao processamento das fibras longas, a partir de madeiras como os pinus.

A partir daí, nos anos que se seguiram pode-se observar um contínuo crescimento e desenvolvimento deste setor no país. Segundo dados do IPT-SENAI (1988, v.1), já em 1986 o Brasil produziu 4,0 milhões de toneladas de pasta de celulose e 4,5 milhões de toneladas de papel, o que corresponde respectivamente a 2,7 e 2,2\% da produção mundial e a 58,3 e 45,1\% da produção da América Latina.

No Brasil em 2000, houve a produção de 7 milhões de toneladas de papel, representando 2,35\% da produção mundial (350 milhões de toneladas). A participação brasileira na produção latino-americana cresceu, sendo atualmente de 48\% (O PAPEL, 2001).

Além disso, enquanto algumas empresas estrangeiras produzem cerca de 15 milhões de t/ano, a maior papeleira do Brasil consegue fabricar apenas 1,5 milhão de t/ano. Como resultado disso, pode-se observar que essa participação brasileira na produção mundial, que é atualmente de $2,35 \%$, demonstra uma evolução de apenas $0,15 \%$ desde 1986 , quando nossa participação foi de $2,2 \%$.

É oportuno observar a fundamental importância dos investimentos de algumas empresas nacionais empregados na cultura da matéria-prima e instalações fabris, bem como a aplicação de estruturas organizacionais e formas de gestão que acompanhassem as tendências e necessidades trazidas pela competitividade mundial característica deste setor e inerentes à globalização. Dentre as empresas brasileiras de destaque em âmbito nacional e internacional, tem-se: Aracruz Celulose, Bahia Sul Celulose, Cenibra Celulose, Companhia Suzano de Papel, Klabin Fabricante de Papel e Celulose, e Votorantim Celulose e Papel. 


\section{O cenário nacional atual}

Segundo SAVASTANO (2000) que verificou dados da Associação Brasileira de Celulose e Papel (BRACELPA), no ano de 2000 as exportações do setor ultrapassaram os US $\$ 2,8$ bilhões contra US $\$ 960$ milhões de importações, o que resultou num superávit de US $\$ 1,847$ bilhões, valor $40 \%$ maior que o de 1999 . No ano de 2001 registrou-se, mesmo num mercado financeiro agitado, um crescimento de $8,6 \%$ no saldo financeiro do setor, tendo-se exportado US\$2,6 bilhões contra US $\$ 860$ milhões de importações, ou seja, gerando um superávit de US\$1,750 bilhões, o que levou o setor ao segundo lugar do ranking nacional de geradores de saldos comerciais nos dois períodos (CAPO, 2000).

No entanto, as disparidades em termos financeiros, investimentos e potencial das plantas industriais do Brasil em relação a alguns países são muito grandes, pois:

“... enquanto o porte financeiro internacional das empresas do setor é de US\$19,5 bilhões, conforme dados de 1998, no Brasil, o da companhia de maior porte financeiro do país, a Klabin, é de US\$9 milhões..." (CAPO, 1999:38).

O consumo de papel no Brasil, no período de 1990 à 1998, cresceu em média 5,6\%. Entretanto, em termos de investimentos, neste mesmo período, dos US \$13 bilhões registrados, grande parte foram aplicados apenas na redução de custos e não em aumento da capacidade de produção, de acordo com dados do Banco Nacional de Desenvolvimento (BNDES) em 2000.

Atualmente no Brasil a taxa de crescimento de consumo de papel é de $3,5 \%$ ao ano, podendo chegar a 5\% ao ano até 2010, enquanto este índice, em âmbito mundial gira em torno de $2,7 \%$, sem grandes perspectivas para o futuro. Já quanto a capacidade instalada do setor no Brasil, está no seu limite. A celulose opera atualmente com $97 \%$ da capacidade produtiva, e os papéis, em geral, já atingem $90 \%$ (SAVASTANO, 2000).

Outra questão importante, é a contínua necessidade de capital estrangeiro que possibilite maiores investimentos e atualizações tecnológicas, fator este favorecido pela geração de superávit da balança comercial nacional, o que vem acentuandose no país nos últimos anos e chamando a atenção de investidores mundiais. Nota-se também uma pré-disposição do setor para aquisições e fusões em âmbito nacional e 
internacional, reflexo de uma tendência do seu mercado mundial.

Diante desses fatores, as empresas nacionais do setor têm buscado investimentos representativos para os próximos 5 anos, que deverão ampliar a capacidade produtiva em $45 \%$ para a celulose e $17 \%$ para o papel, haja vista os projetos já anunciados. Um exemplo desses investimentos é o projeto da Veracel Celulose, que deverá produzir celulose com uma capacidade produtiva inicial de 750.000 t/ano, com previsão de inicio de operação para 2005 (CAPO, 1999).

Focando-se no processo de produção desenvolvido pelas empresas deste setor, tem-se atualmente uma estratégia voltada para contínua otimização do processo. Grandes investimentos são realizados em tecnologia e no desenvolvimento dos recursos humanos, visando obter características que proporcionem a confiabilidade do processo, a máxima produtividade e qualidade e, com isso a garantia da competitividade nesse mercado.

Como exemplo, verifica-se que na VCP_LA, com capacidade de produção de $1.400 t$ de celulose e $1.100 t$ de papel por dia, uma hora de produção significa US\$ 25.000,00. A partir destes valores, nota-se a importância da confiabilidade da planta, bem como de evitar paradas imprevistas.

\subsection{O Grupo Votorantim Celulose e Papel - VCP}

O Grupo VCP surgiu em 1988, quando adquiriu a planta industrial de celulose e papel do Grupo Silva Gordo, na época ainda em fase de construção, situada no município de Luiz Antônio, ao norte do Estado de São Paulo.

Em 1992, então chamado de CELPAV, o Grupo adquiriu o controle acionário da Papel Simão, grupo constituído por quatro unidades industriais: Jacareí (SP), unidade integrada de produção de celulose e papel; Mogi das Cruzes (SP), Piracicaba (SP) e Pedras Brancas (RS), unidades de produção de papéis; sendo que esta última foi vendida em 1998 por questões estratégicas. Com essas aquisições, a VCP consolidou-se no setor papeleiro, dupli-cando sua capacidade produtiva, tanto de celulose como de papel, e ampliando seu mix de produtos de mercado.

A partir de 1994, após algumas reestruturações organizacionais e cor- 
porativas, a fim de obter um padrão de gestão nas suas unidades industriais e a centralização de algumas áreas estratégicas, a VCP iniciou um forte ciclo de investimentos nos seus processos produtivos e administrativos na ordem de US\$1 bilhão, um dos maiores do setor na década de 90.

Visando ao fortalecimento em alguns segmentos de mercado, os principais focos desses investimentos foram: a celulose, com US\$450 milhões; o desenvolvimento tecnológico das suas unidades florestais, com US\$225 milhões; os papéis para imprimir e escrever, onde foram envolvidos aproximadamente US\$170 milhões; e fortes investimentos em programas e técnicas de gestão e treinamentos para valorização e capacitação de seus recursos humanos (VCP_LA, 2000).

Em 1995, o Projeto Repensar - PR, implantado em todas as unidades de negócio do Grupo VCP, veio consolidar e demonstrar esse perfil. Também, neste mesmo ano, houve a qualificação internacional como fornecedor exclusivo do Grupo Xerox Internacional, o que representou a ascensão no mercado mundial.

Em 1996, a capacidade instalada da VCP já era de 1 milhão de toneladas ao ano de celulose e 600.000 toneladas ao ano de papel, estando entre os três maiores produtores brasileiros. Nas unidades integradas, houve a substituição do processo tradicional de colagem ácida para o de colagem alcalina do papel e, em 1997 foi investido na produção da celulose Elementar Cloro Free $(E F C)$, produto de alta demanda nos mercados europeu e asiático, demonstrando assim a contínua busca pela alta qualidade e ampliação das exportações, sempre visando a consolidação da marca em contexto mundial.

Em meados de 1998, com o projeto Sistemas Integrados de Informações - SII, foram feitos pesados investimentos em softwares especializados em gestão integrada de processos administrativos e industriais e, para isso, foram adquiridos vários sistemas computacionais.

Ao final da década de 90, o Grupo VCP firmou-se como o maior produtor e vendedor de papel para imprimir e escrever da América Latina, tendo $20 \%$ das suas exportações distribuídas pelos países que compõem o Mercosul, exportando para 45 países dos cinco continentes (VCP_LA, 2000).

Outra característica que contribui para a consolidação do Grupo VCP no setor, e que permanece até hoje, além dos altos investimentos e a visão sempre 
voltada para o mercado externo, foi sua auto-suficiência quanto à matéria-prima. Suas unidades florestais totalizam uma área plantada de 102.000 hectares de eucaliptos, onde são aplicadas culturas de alta tecnologia, como a clonagem de mudas; que permite o controle da uniformidade no desenvolvimento do eucalipto e composição das fibras da celulose.

Suas unidades industriais apresentam um aproveitamento muito eficiente dos resíduos de processo em todo o ciclo produtivo, proporcionando uma geração de $80 \%$ da energia total consumida pelas plantas fabris. A preocupação com o meio ambiente e a interação da empresa junto a sociedade também são características fortes e determinantes na atuação do Grupo.

No ano de 2000, segundo dados internos da VCP_LA, o Grupo:

“... obteve um crescimento na receita liqüida de $28 \%$ sobre o exercício de 99, atingindo $R \$ 1.437$ milhões. Um dado histórico."

A geração operacional de caixa da VCP totalizou $\mathrm{R} \$ 713$ milhões, o que configurou um crescimento de 52\% sobre o ano de 1999 e, o lucro líquido de R\$ 394 milhões foi superior em 144\% em relação ao de 99, quando obteve-se R \$ $161 \mathrm{mi}$.

"Com isso, a empresa [o Grupo VCP] não somente manteve sua liderança em praticamente todas as linhas de produto, como expandiu seu volume de vendas e alcançou, por decorrência, um acréscimo de $54 \%$ na receita liqüida proveniente de celulose, correspondendo a $R \$ 380$ milhões, e de $21 \%$ no segmento de papel, o que somou $R \$ 1.057$ milhões." (VCP NOTÍCIAS, jan.fev./2001:23).

Quanto à condição do Grupo VCP no mercado de valores, este vem em crescente evolução e ocupa atualmente uma posição de destaque em relação às empresas do setor. Para Mauritz Folkerts, vice-presidente do banco Chase Manhattan, a margem de geração de caixa da VCP aumentou assombrosamente, a partir das exportações, sendo a única empresa brasileira do setor que ultrapassou a marca de US\$1 bilhão, o que caracteriza suas ações como as que mais subiram no ano de 1999 (SAVASTANO, 2000).

No início do ano de 2001, a VCP lançou o Programa Revitalização, cujo principal objetivo era preparar a empresa para o ambiente de mercado futuro e, para isso, reforça e padroniza os conceitos e a visão da empresa, lançados em 1995 com o PR, e alicerçados em dois aspectos estratégicos: a qualidade total e o 
desenvolvimento organizacional. Através desse projeto global, buscava-se uma gestão única de cerca de 20 projetos específicos que corriam em paralelo, voltados aos processos administrativos e produtivos, em cada uma das unidades industriais.

Como um resultado positivo pela busca contínua das melhores práticas gerenciais e pelo desenvolvimento de seus profissionais, o Grupo VCP, representado pela Unidade LA, obteve notas máximas e venceu a etapa 2000 do Global Excellence in Operations Awards - GEO. O GEO é um programa mundial que tem o objetivo de identificar empresas líderes em excelência e estimular o uso das melhores práticas mundiais de operação, sendo criado e desenvolvido pela A.T. Kearney, empresa de consultoria tida como uma das mais respeitadas do mundo pelo setor.

Esse prêmio, segundo Francisco Valério (vozes, 2001), diretor técnico e industrial da VCP, reflete os bons resultados dessa Unidade no ano de 2000, quando a fábrica de Luiz Antônio foi responsável por $\mathrm{R} \$ 560$ milhões dos $\mathrm{R} \$ 1,437$ bilhão gerados pelo Grupo em termos de resultado líquido no período.

\subsubsection{A Unidade Luiz Antônio (VCP_LA) - Visão geral da organização e do processo de fabricação}

A Unidade Luiz Antônio situa-se na região de Ribeirão Preto, ao norte do Estado de São Paulo, mais especificamente no município de Luiz Antônio, a 320 quilômetros da capital do Estado e às margens do Rio Mogi Guaçu.

Segundo dados oficiais da Unidade, internamente publicados em janeiro de 2001, a produção média da unidade é de 360.000 t/ ano de celulose e 315.000 t/ ano de papel, onde são consumidas 2,13 t de madeira/ ADt.

Atualmente, toda a matéria-prima utilizada pela indústria é fornecida pela Unidade Florestal Luiz Antônio, que possui uma área plantada de aproximadamente 50.000 hectares. A produtividade da madeira é de $43 \mathrm{~m}^{3} /$ hectare ao ano e seu rendimento é de $52 \%$ no processo industrial.

A madeira utilizada é o eucalipto, adequada para fabricação de celulose e papel de fibras curtas, e o processo de polpação (cozimento das fibras) desenvolvido é o denominado "Kraft" (mais detalhes vide item 2.3.4). 
Basicamente, o processo é suprido de toras de 2,40 a 3,70 metros de comprimento, com casca, sendo que para se obter a qualidade desejada é realizado um mix de espécies de Eucalyptus, no caso 65\% de Urophylla e 35\% de Saligna. Também, há uma classificação por densidade: alta, média e baixa. A combinação de toda a matéria-prima que entra, em média, é de $19 \%$ de baixa densidade, $24 \%$ de média densidade e $57 \%$ de alta densidade.

Quanto aos insumos utilizados pela Unidade, são consumidos $55.000 \mathrm{~m}^{3} /$ dia de água, captados pela Estação de Captação diretamente do Rio Mogi Guaçu. O consumo de energia é de $58 \mathrm{MWh}$, onde $55 \%$ provem de geração própria. Como exemplo, tem-se a matriz energética que compôs essa geração no ano 2000:

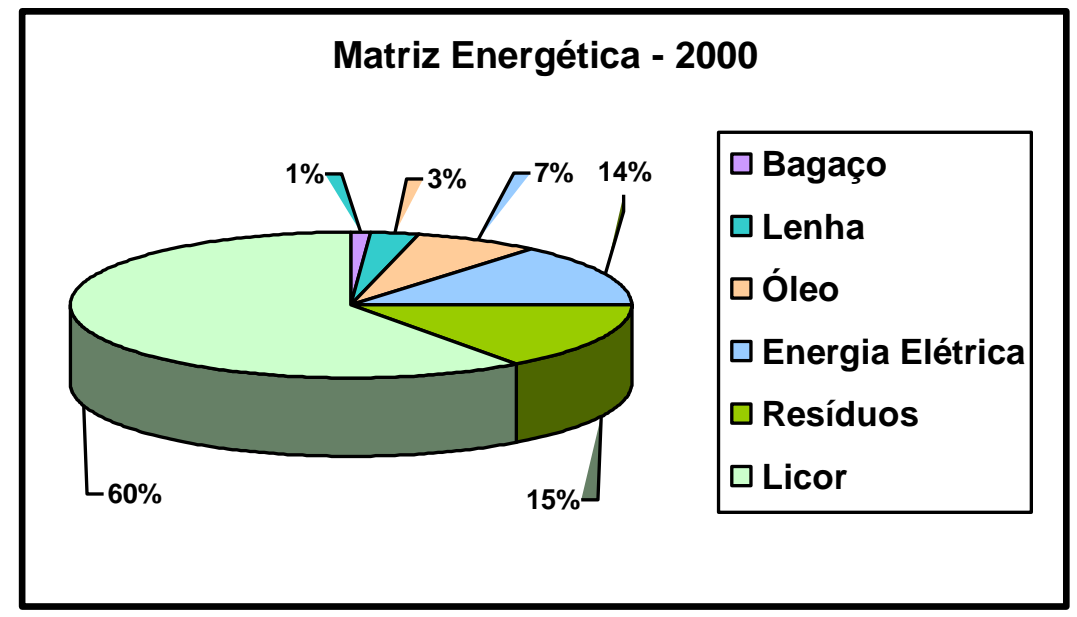

Figura 2.2 - Matriz energética da VCP_LA no ano 2000 (VCP_LA, 2000).

Finalmente, os recursos humanos estão subdivididos da seguinte forma: na Unidade Industrial tem-se 780 funcionários próprios e 346 profissionais de empresas terceirizadas e, na Unidade Florestal, 263 próprios e 304 de terceiros, perfazendo um total de 1.693 pessoas diretamente envolvidas. É importante observar que desde o start-up da planta fabril foram investidos US\$ 800 milhões na VCP_LA.

\subsubsection{Estrutura organizacional da indústria}

Em 1995, com a implantação do PR, houve a subdivisão da Organização em Células de Trabalho (CT), tanto de processos administrativos como produtivos, e estas em Times (equipes). 
Como pode-se notar na figura 2.3, três são de âmbito administrativo e as outras compõem os processos de fabricação, todas coordenadas por uma Gerência Geral. Assim, houve o desmembramento administrativo do processo produtivo, dividindo a fábrica em sub-processos, cujo principal objetivo era promover uma atuação mais efetiva entre as equipes de operação e manutenção, bem como garantir um gerenciamento de cada processo mais próximo das plantas e mais adequado a cada necessidade.

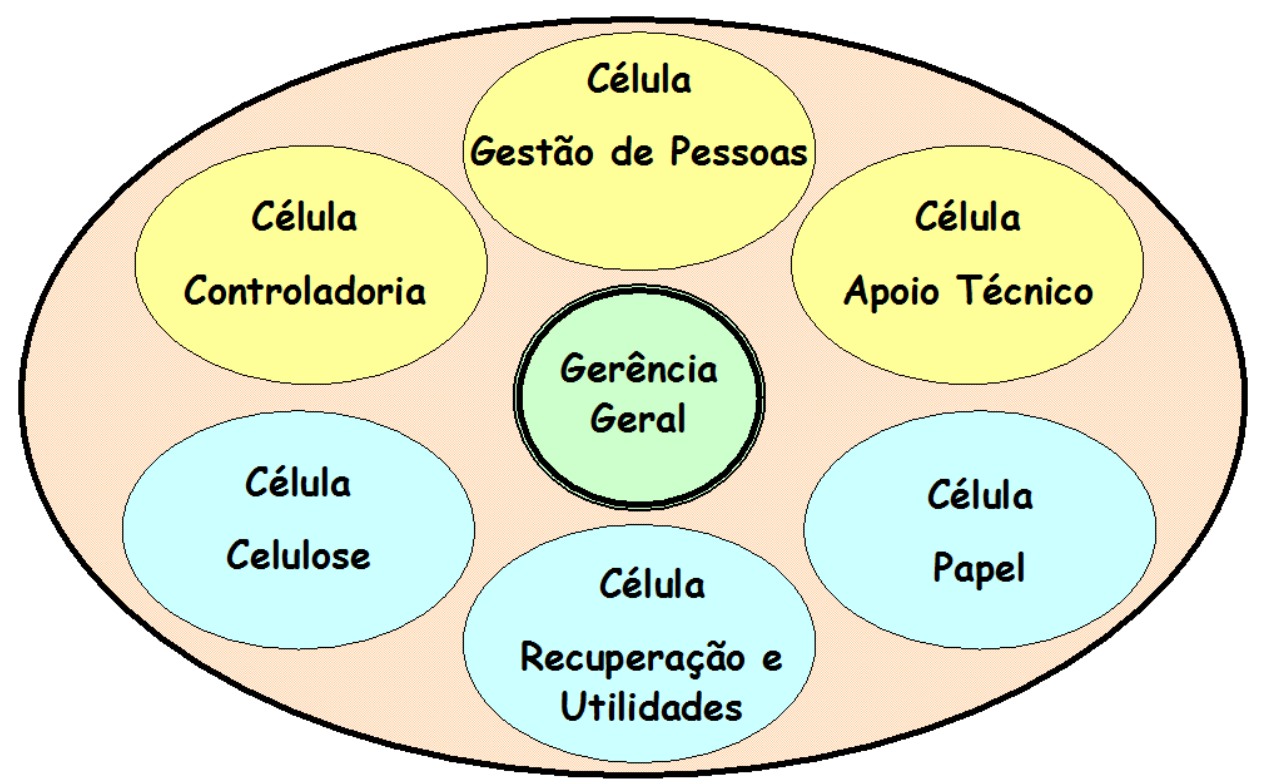

Figura 2.3 - Estrutura organizacional da VCP_LA (ano 2000).

A área de manutenção foi uma das mais atingidas, pois parte dela incorporou-se a cada CT produtiva, estimulando uma maior participação dos profissionais destas no processo de fabricação como um todo. Um outro grupo, formado por engenheiros especialistas e técnicos de inspeção, compôs uma equipe de Apoio Técnico (CAT) com a função de dar suporte aos grupos produtivos.

\subsubsection{Sistemas informatizados e softwares de apoio}

Devido à alta complexidade do processo desenvolvido, além dos aspectos de segurança envolvidos, toda a planta fabril da VCP_LA é controlada via Sistema Distribuído de Controle Digital (SDCD), um sistema de monitoramento contínuo de 
equipamentos que garante o controle efetivo de todas as variáveis do processo, o qual é transferido para telas de controle.

Buscando tornar as informações mais ágeis, transparentes e de melhor qualidade, e dessa forma uma maior assertividade na tomada de decisões gerenciais e estratégicas. Como já comentado, em meados de 1998 foi lançado o projeto Sistema de Informações Integradas (SII), sendo este composto por quatro softwares integrados:

- $S A P / R 3$ - Sistema de gestão de processos administrativos, industriais, financeiros, comerciais, suprimentos, pesquisa e desenvolvimento.

- MANTEC Web - Software especialista de gerenciamento, planejamento e controle de manutenção.

- PEOPLE SOFT - Sistema para gestão de recursos humanos.

- SISPLO - Sistema para gestão patrimonial.

É importante observar-se que esses softwares têm interfaces entre sí e são integrados para todas as Unidades do Grupo.

Em abril de 2001, foi implantado um software denominado Plant Information $(P I)$, constituído por um sistema de supervisão de processo onde é possível a edição de relatórios e gráficos para o acompanhamento da produção, consumos, performance de equipamentos, entre outros. Através de milhares de variáveis proporciona uma análise especialista do processo, de uma forma pontual e personalizada.

Por fim, através de análises específicas, realizadas no Laboratório Químico da Unidade, todos os parâmetros são checados manualmente, obtendo-se um acompanhamento e monitoramento do processo em vários pontos. Esses dados, em confronto com os apontados pelo sistema, são checados periodicamente para garantir o perfeito andamento do processo.

\subsubsection{Produtos de mercado}

A Unidade Luiz Antônio é fornecedora nos três processos em que atua: celulose, papel e madeira de eucalipto, sendo que esta última é utilizada apenas para 
consumo próprio. A celulose é produzida em pasta para as duas Máquinas de Papel (MP) e em fardos, prensados a 55\% seco, para as fábricas não integradas do Grupo.

Quanto ao papel, são produzidos os de imprimir e escrever, existindo variações no tipo, gramatura e formato. A gramatura define a espessura da folha, variando de 50 a $90 \mathrm{~g} / \mathrm{m}^{2}$.

Vários tipos de papéis compõem o mix oferecido (em três formatos): os para impressão padrão, a laser, máquinas copiadoras e papel sulfite. Dessa variedade de papéis produzidos, $53 \%$ é voltado ao mercado externo e $47 \%$ ao interno.

\subsubsection{Unidade Florestal Luiz Antônio}

Desde o início das operações do Grupo VCP, o cultivo da matéria-prima necessária para o processo sempre foi tido como um processo estratégico para suas metas, devido principalmente a seus objetivos de auto-suficiência em matéria-prima, bem como à fabricação de uma celulose e papel de altíssima qualidade, visando os mercados externo e interno.

Atualmente, conta-se com uma área plantada de aproximadamente 50.000 hectares, onde são cultivadas árvores de eucaliptos de todas as espécies e densidades necessárias. Para obtenção de uma madeira de alto potencial de rendimento e, que garanta a qualidade desejada, são utilizados processos que envolvem alta tecnologia, como a clonagem de mudas, o qual permite o controle da uniformidade no desenvolvimento do eucalipto e a composição das fibras.

A plantação tem uma rotatividade de no máximo 7 anos, período de tempo necessário para que as árvores atinjam as características e o tamanho ideal de corte para utilização no processo de fabricação da celulose. As árvores são colhidas de forma adequada para o transporte e utilização, normalmente são cortadas em toras de 2,40 a 3,70 metros de comprimento.

As toras são colocadas em caminhões no campo, transportadas até a fábrica e descarregadas, sendo registrada a entrada de aproximadamente 150 caminhões de madeira por dia, tendo-se em média 25 toneladas por caminhão. Toda a produção desta Unidade Florestal é consumida pela VCP_LA. 


\subsubsection{A produção de utilidades}

A VCP_LA necessita de insumos em grandes quantidades para suprir seu processo, com um aproveitamento eficiente dos resíduos em todo o ciclo produtivo, além da redução ao máximo da emissão de resíduos. Para isso, a geração de "utilidades", para utilização e reutilização no processo são essenciais e estratégicas, destacando-se: água, energia elétrica, vapor e ar comprimido.

Como principais equipamentos e sistemas para suprir as necessidades em relação a água, têm-se:

- Poços Artesianos: Através dos quais toda necessidade de água potável da Unidade Industrial é suprida.

- Estação de Captação de Água (ECA): Captação direta do Rio Mogi Guaçú, com um consumo médio atual de $55.000 \mathrm{~m}^{3} / \mathrm{dia}$. Essa Estação tem capacidade nominal para $70.000 \mathrm{~m}^{3} / \mathrm{dia}$, atendendo todas as áreas da fábrica, tanto administrativa quanto de processo.

- Estação de Tratamento de Água (ETA): Aqui dá-se o tratamento de água para utilização em toda planta, tendo-se uma capacidade para o processamento de $80.000 \mathrm{~m}^{3} /$ dia. Dois são os principais produtos dessa Estação - a água de selagem, utilizada para evitar vazamentos em equipamentos rotativos por pressão; e a água de fábrica, que é utilizada de forma geral pelas áreas (para limpezas, hidrantes etc...), aplicada diretamente em alguns processos, e utilizada na alimentação das plantas de Osmose Reversa e Desmineralização, onde recebem um tratamento específico para utilização nas caldeiras.

- Planta de Desmineralização: Promove o tratamento de água por troca iônica para utilização nas caldeiras, nesse caso duas CF e uma CR, apresentando uma capacidade nominal de $75 \mathrm{~m}^{3} / \mathrm{h}$.

- Planta de Osmose: Faz o tratamento de água pelo processo de osmose reversa para utilização, neste caso, nas duas $\mathrm{CF}$. Tem capacidade nominal de $50 \mathrm{~m}^{3} / \mathrm{h}$.

- Estação de Tratamento de Efluentes (ETE): Nesta Planta dá-se o tratamento de efluentes dos processos de fabricação de papel, celulose e recuperação química, além dos efluentes sanitários, possuindo capacidade para um volume de $2.850 \mathrm{~m}^{3} / \mathrm{h}$. Em 2000, iniciou-se um projeto de repontenciamento, com perspec- 
tiva de ampliação de capacidade e eficiência em cerca de $30 \%$, a fim de sua adequação às necessidades atuais do processo.

Quanto a energia elétrica, onde tem-se um consumo médio de $58 \mathrm{MWh}$, $55 \%$ provem de geração própria através de duas turbinas a vapor, destacam-se como principais equipamentos e sistemas:

- Caldeiras de Força (CF): têm-se duas caldeiras desse tipo, cujo principal combustível utilizado para produção de vapor é a biomassa, resíduo resultante do descascamento da madeira, com uma capacidade nominal de $60 \mathrm{t} / \mathrm{h}$ cada uma, sendo que atualmente são responsáveis por aproximadamente $30 \%$ da geração de energia própria da Unidade Industrial. O restante da produção de vapor vem do processo de Recuperação Química, que será abordado à seguir.

- Turbo Geradores (TG): Tem-se duas turbinas a vapor responsáveis pela geração de $34 \mathrm{MWh}$ de energia.

Essas turbinas transformam o vapor de alta pressão (VAP) vindo das caldeiras em energia elétrica. O restante da energia consumida (45\%) é proveniente de Concessionária, nesse caso a Companhia Paulista de Força e Luz (CPFL). Toda essa energia elétrica se une e passa pela Subestação de Entrada Principal (SEP), onde tem-se seccionadoras e transformadores que fazem a equalização e a distribuição para toda a fábrica.

Além da utilização do vapor para alimentar os Turbo Geradores com VAP, tem-se também os vapores de média e baixa pressão, respectivamente VMP e VBP. Como principais aplicações do VMP destacam-se: a etapa de cozimento da massa celulósica, mais especificamente no Digestor; e sua utilização nas etapas de secagem da folha nas MP.

Já o VBP é utilizado no processo de Evaporação e nas MP principalmente para aquecimentos. Além disso, ele é condensado e desaerado (sem oxigênio) para utilização nas partes de pressão das caldeiras.

Finalmente, tem-se o ar comprimido, que é retirado da atmosfera, filtrado e processado em três Compressores de Ar, com capacidade nominal de $6.000 \mathrm{cfm}$ cada. Esse ar processado é utilizado de duas formas: como ar de fábrica, onde as áreas o aplicam em limpezas e equipamentos pneumáticos em geral; e como ar para instrumentos, o qual é desumidificado antes do uso. 


\subsubsection{O processo de recuperação química}

Este processo proporciona um aproveitamento eficiente de todo o ciclo produtivo, com a recuperação dos resíduos do processo para sua reutilização, além da geração de energia e da redução da emissão de substâncias poluentes através de um "ciclo fechado" (IPT-SENAI, 1988), como apresentado na figura 2.4. No presente caso, tem-se a recuperação de um resíduo formado no processo de polpação da celulose, o licor negro fraco, que é enviado à Planta de Evaporação onde inicia-se o processo de recuperação química, constituído ainda por uma Caldeira de Recuperação Química e plantas de Caustificação e Calcinação.

Os principais equipamentos e sistemas que compõem esse processo são:

- Evaporação: O licor negro fraco proveniente do Digestor e retirado do processo de produção de celulose na etapa de Lavagem é enviado diluído em água à Evaporação, onde é aquecido e evaporado tendo sua concentração aumentada, ganhando alto potencial energético para ser utilizado como combustível na CR, agora como licor negro forte. Este processo tem como característica a evaporação em duas fases, sendo: a primeira em um pré-evaporador, constituído de um ventilador com capacidade de $220 \mathrm{t} / \mathrm{h}$; e a segunda em um sistema composto por um evaporador de seis efeitos e um Stripping, com capacidade de $90 \mathrm{t} / \mathrm{h}$.

- Caldeira de Recuperação Química (CR): O licor negro forte proveniente da Evaporação é queimado na Caldeira produzindo vapor, um subproduto que resulta na geração de cerca de $70 \%$ da energia elétrica produzida na Unidade Industrial. O licor resultante dessa queima é pré-misturado com outra substância, o licor verde fraco, proveniente da Planta de Caustificação e a mistura é enviada à mesma para ser novamente recuperada. Além disso, esse processo tem o papel de reduzir ou eliminar os resíduos tóxicos, a partir de sua queima, tendo uma capacidade atual de queima de 1.400tSS (tonelada de sólidos secos) ao dia.

- Caustificação: O licor verde vindo da CR é primeiramente misturado com cal nos caustificadores nesta etapa. Parte dessa mistura solidifica-se formando partículas chamadas dregs e grits que são utilizadas como adubo pela Unidade Florestal, enquanto a outra parte entra em uma fase de decantação, sendo a lama decantada enviada ao processo de Calcinação para recuperação do cal e a mistura líquida 
enviada ao Digestor para sua utilização no processo de polpação, agora como licor branco, "fechando-se" assim o circuito de Recuperação Química. Essa planta possui uma capacidade de produção de $4.200 \mathrm{~m} 3$ de licor branco ao dia.

- Calcinação: Este processo recupera a lama de cal proveniente da Caustificação através de um forno de cal rotativo, o qual seca a lama com altas temperaturas transformando-a em cal seco. Esse cal resultante é enviado aos Caustificadores onde é misturado com o licor verde, reiniciando o processo de Caustificação, enquanto o $\mathrm{CO}_{2}$ resultante dessa queima é utilizado para a produção de carbonato de cálcio $(P C C)$.

- Planta Specialt Mineral International (SMI): Neste processo é produzido o PCC, uma substância utilizada nas MP na etapa de preparação de massa, com várias finalidades: melhorar as características de printabilidade do papel, dar maior vivacidade na brancura, baratear os custos do produto final, entre outros. $\mathrm{Na}$ produção do $P C C$ é utilizado o $\mathrm{CO}_{2}$ resultante da queima da lama de cal no Forno Rotativo durante o processo de Calcinação. Vale ainda ressaltar que esta planta não pertence a VCP_LA, sendo uma prestadora de serviços integrada.

Para ilustrar o ciclo fechado referente a esse processo de recuperação química, tem-se o fluxograma apresentado na figura 2.4.

\section{Ciclo de Recuperação Química}

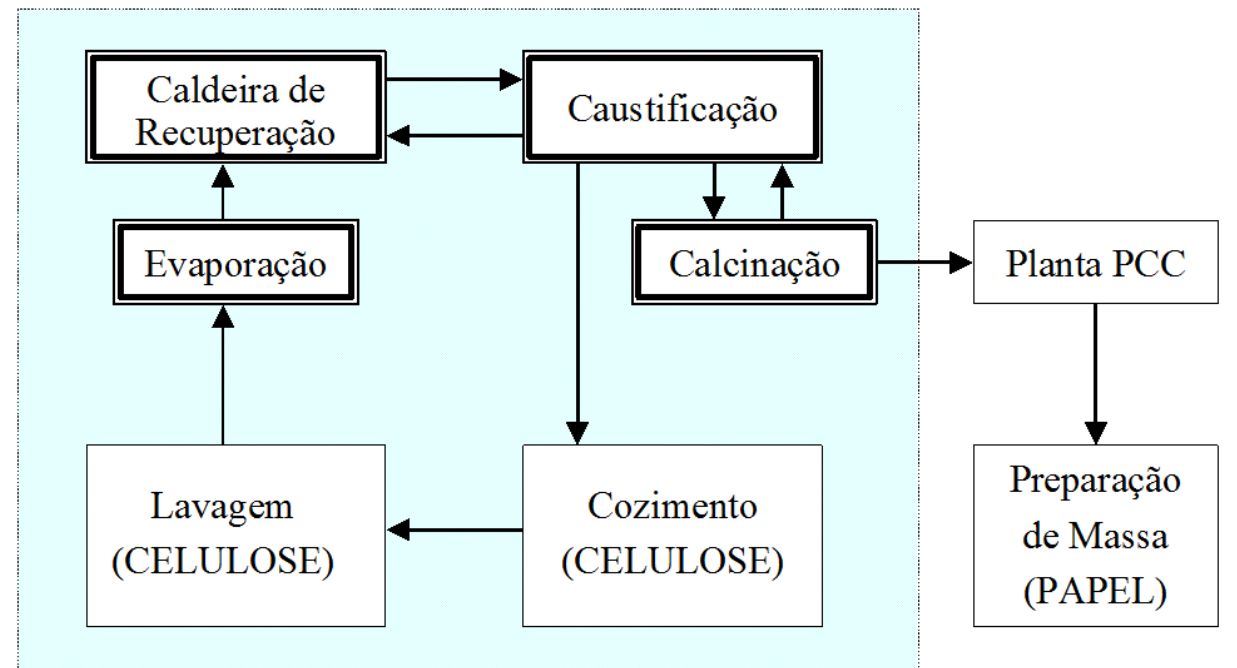

$\square$ Plantas da Célula de Recuperação e Utilidades (CRU).

Figura 2.4 - Fluxograma de processo: Recuperação Química VCP_LA. 


\subsubsection{A produção da celulose e do papel}

Segundo IPT-SENAI (1988), a obtenção da pasta celulósica dá-se através de processos de polpação (cozimento) onde as fibras que formam a madeira são separadas mediante a utilização de energia química e/ou mecânica, à alta temperatura e pressão. Na Unidade Luiz Antônio, ambiente de desenvolvimento e verificação deste trabalho, a celulose é produzida a partir de um processo de polpação denominado Kraft ou Sulfato, o qual consiste no tratamento das fibras da madeira com soluções alcalinas aquosas, onde os principais reagentes são o hidróxido de sódio e o sulfeto de sódio.

Também nesta planta, a celulose é produzida tanto em pasta, para consumo interno, quanto em fardos prensados, para o transporte e utilização em fábricas do Grupo que possuem apenas processos para produção do papel.

Para simplificar o entendimento do processo desenvolvido, tem-se o fluxograma apresentado na figura 2.5 abaixo:

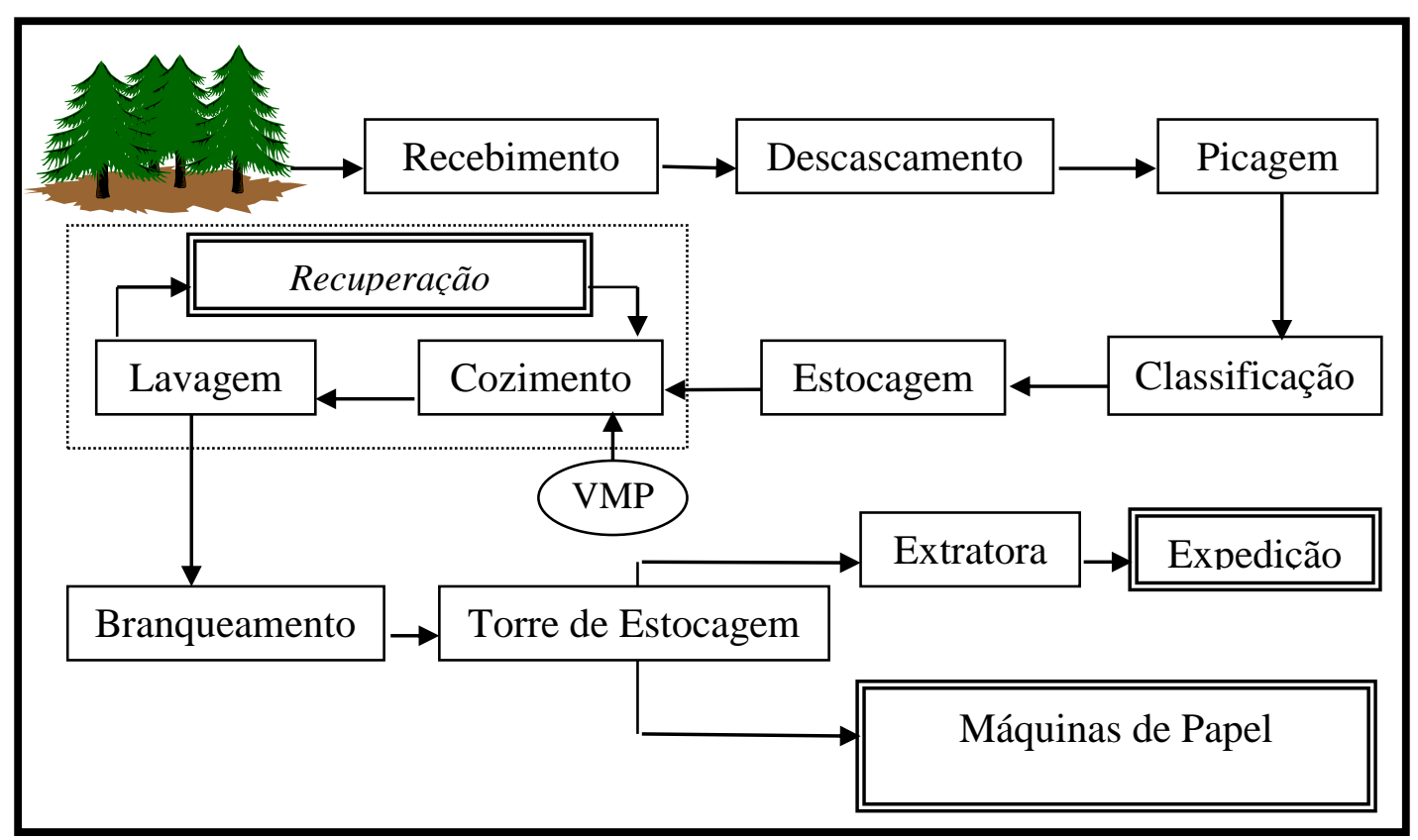

Figura 2.5 - Fluxograma de processo: Celulose VCP_LA.

Como mostra este fluxograma, as principais etapas para obtenção da celulose branqueada (ADt) são: Recebimento, Descascamento, Picagem, Classificação, Estocagem, Cozimento, Lavagem, Branqueamento, Torre de Estocagem, Extração e Expedição. 
Ainda, faz-se importante ressaltar que todas as etapas deste processo são acompanhadas e monitoradas por pesquisas e testes em laboratório, sendo estes realizados no Laboratório Químico da Unidade.

Quanto à produção do papel, o processo desenvolvido é adequado à fabricação de papéis para imprimir e escrever, podendo-se obter variações no tipo, gramatura e formato do papel, como comentado no item 2.3.1.

Para simplificar o entendimento desse processo, tem-se:

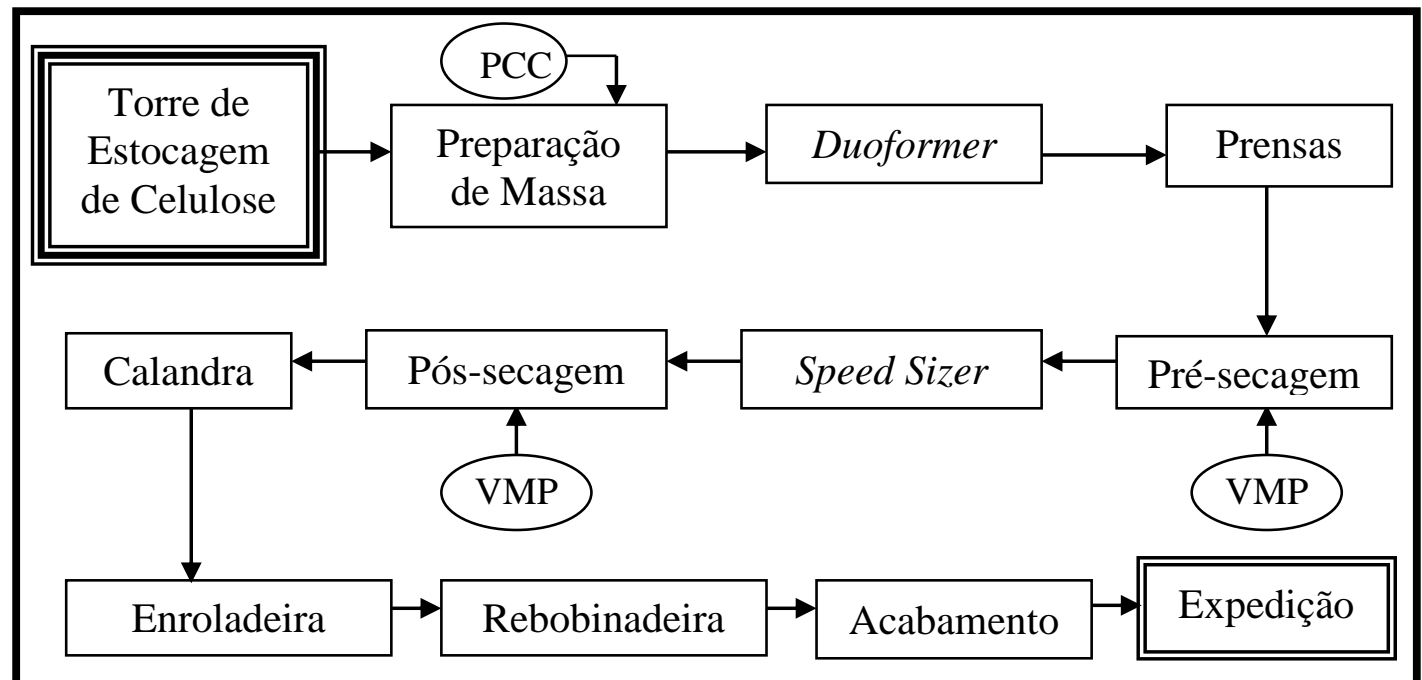

Figura 2.6 - Fluxograma de processo: Papel VCP_LA.

Como principais etapas na fabricação do papel alcalino, têm-se: Preparação de Massa, Duoformer, Prensas Desaguadoras, Pré-secagem, Speed Sizer, Pós-secagem, Calandras, Enroladeira, Rebobinadeira, Acabamento e Expedição.

Alguns detalhes de cada uma dessas etapas do processamento da celulose e do papel são apresentadas no glossário do presente trabalho.

Ainda, vale ressaltar que a planta desta Unidade possui duas Máquinas de Papel, com uma capacidade de produção total de 1.050 t/ dia. Todo o processo é controlado via SDCD, e as anormalidades apontadas através do Sistema PI.

\subsubsection{Controle do meio ambiente}

Todas as substâncias com potencial tóxico geradas pelo processo são recuperadas, tratadas e monitoradas. Assim, tem-se: 
- os efluentes líquidos sanitários e vindos do processo, tratados na ETE, Planta já descrita neste capítulo e que garante o retorno de uma água de boa qualidade para o rio;

- os gases concentrados, vindos da etapa de cozimento no Digestor e eliminados pela queima em sistemas de gases concentrados e diluídos na Evaporação e CR;

- os gases condensados da Evaporação, tratados no Sistema Stripping Integrado - SIS e na coluna de metanol;

- os gases de combustão, tratados e reduzidos em Precipitadores Eletrostáticos (PE's) e Multiciclones, que retiram o excesso de partículas e promove o seu retorno para o processo de recuperação.

Todo o sistema de emissão de gases para a atmosfera é controlado e monitorado continuamente através de analisadores, como: de teor residual de enxofre - TRS, de oxigênio, de gás carbônico, entre outros. A opacidade ou a cor da fumaça também são monitorados nas chaminés por instrumentos específicos.

Já os sólidos residuais, são em parte utilizados na Unidade Florestal como fonte de nutrientes, ou enviados aos aterros sanitários do município.

Além disso, a Unidade é periodicamente auditada por órgãos de proteção ambiental, como a Companhia de Tecnologia e Saneamento Básico (CETESB), além de promover um auto-monitoramento contínuo e efetivo, a fim de garantir índices adequados e aceitáveis, dentro dos padrões internacionais. Também, junto a esses órgãos de controle governamentais, analisa os índices de contaminação do solo em vários pontos distribuídos pelas áreas periféricas a planta fabril. 


\section{CAPITULO 03}

\section{A MANUTENÇÃO NO SETOR PAPELEIRO}

\subsection{Introdução}

Durante quase dois mil anos de evolução, o processo de fabricação da celulose e do papel, mesmo com a aplicação de muita tecnologia e investimentos, e passando de uma produção artesanal para um sistema de produção contínua, manteve seus fundamentos. Para CHIAVENATO (1990:13), a produção contínua:

"É o sistema de produção utilizado por empresas que produzem um determinado produto, sem mudanças, por um longo período de tempo. $O$ ritmo de produção é acelerado e as operações são executadas sem interrupção. Como o produto é sempre o mesmo ao longo do tempo, o processo de produção não sofre mudanças e pode ser aperfeiçoado continuamente".

Muita tecnologia foi agregada ao processo de fabricação de celulose e papel, que é atualmente desenvolvido por máquinas complexas controladas por computadores que produzem cerca de 80 milhões de folhas de papel por dia no mundo. Para isso, todas as suas fases são otimizadas continuamente, por meio de adequações na forma de produzir e através da implantação de equipamentos mais avançados e eficazes.

Nesse contexto, segundo SALERNO (1994), atualmente o papel dos operadores em um processo de produção contínua é acompanhar e manter o processo sob controle, ajustando os parâmetros reais de operação de acordo com padrões preestabelecidos.

Também, como lembra NAGAO (1998), todas as informações do processo como pressão, vazão, nível, temperatura e outras são enviadas para a sala de controle através de sensores instalados nos equipamentos. Muitas vezes, mesmo com a detecção de anormalidades, nem sempre é possível e seguro a interrupção do ritmo normal de produção, sendo fundamental que após uma parada tenha-se a "confiança" 
de que a instalação irá operar sem grandes problemas até uma próxima parada geral que poderá ser daqui a 1 ou 2 anos.

Neste ambiente de produção existem duas preocupações básicas para a equipe de manutenção, como escreve NAGAO (1998):

- Garantir a continuidade operacional da planta, maximizando a sua disponibilidade.

- Gerenciar a confiabilidade dos equipamentos e das instalações industriais minimizando a falha, garantindo a integridade do homem (funcionários e comunidade) e os impactos ao meio ambiente.

Portanto, o grande desafio da manutenção é atender a esses dois objetivos, sempre otimizando o uso de seus recursos produtivos como mão-de-obra, materiais e serviços.

A missão e a visão das equipes de manutenção neste enfoque devem estar baseadas no desenvolvimento de uma gestão voltada à "antecipação as falhas" e a "quebra zero (ZD)", tendo como principal meta a disponibilidade total da planta. O estabelecimento de uma forte política de manutenção, aliada à gestão para a qualidade, adequada e efetiva ao processo desenvolvido, pode garantir o atendimento dessas preocupações através da confiabilidade operacional da planta fabril.

\subsection{Uma Política de Manutenção Efetiva}

Muitos autores definem "política de manutenção" em uma frase ou um conjunto de diretrizes. No contexto deste trabalho, a política de manutenção será tratada como a forma de atuação e ação da equipe de manutenção para com o processo, instalações e a própria organização, ou seja, constituída, padronizada e aplicada diante uma gestão da função manutenção integrada aos objetivos macros da organização.

Face ao processo de produção desenvolvido, NAGAO (1998) esclarece que o melhor esquema de manutenção é aquele adequado à instalação industrial, e para que seja traçada uma política de manutenção efetiva alguns fatores técnicos devem ser analisados: 
- Criticidade do equipamento dentro do fluxo produtivo.

- Estratégias do produto e instalações a curto, médio e longo prazo.

- Adequação dos equipamentos ao processo.

- Custos da intervenção quando da perda de produção.

- Impacto causado para a segurança industrial e ao meio ambiente devido à falha.

- Política de sobressalentes e equipamentos reserva.

Neste sentido, a atuação da manutenção face a uma planta de produção de celulose e papel é estruturada de acordo com as necessidades específicas das suas instalações, como: aplicação de diversos tipos de manutenção, particularidades da operacionalidade do processo, necessidades da equipe operacional (limpezas e inspeções), entre outras. Além disso, para a gestão da produção, a equipe de manutenção deve ser fundamental na estrutura da empresa, centralizando as informações, interagindo com todas as áreas afins, gerenciando a confiabilidade e a disponibilidade.

"O melhor esquema de Manutenção está voltado ao Conhecimento. (...) A Manutenção voltada a Produtividade passa necessariamente por uma Visão Holística: Máquina, Homem, Processo e Ambiente [de trabalho]." (NAGAO, 1998: 24).

$\mathrm{Na}$ busca por esta sinergia, e com a utilização de uma forma de gestão estratégica e voltada à produtividade, confiabilidade, disponibilidade e ao conhecimento, aplicam-se metodologias, técnicas e ferramentas visando a obtenção de bases para o estabelecimento de uma política de manutenção adequada e efetiva. ANHESINE (1999) esclarece que uma vez conhecidos e analisados os problemas da área, o grupo discute e propõe uma política de manutenção para a planta, a qual define as diretrizes gerais de atuação para a consecução dos objetivos traçados, de acordo com a estratégia do negócio da atividade industrial.

Neste contexto, a máxima disponibilidade do processo produtivo é buscado com a aplicação de práticas básicas de manutenção, as quais determinam as formas de intervenção que devem ser utilizadas. Vários trabalhos específicos em processos contínuos caracterizam seis tipos de manutenção: manutenção corretiva não planejada, corretiva planejada, preventiva, preditiva, detectiva e a engenharia de manutenção. 
Nas indústrias papeleiras, por exemplo, há maior aplicação da manutenção preditiva, em detrimento da preventiva, o que é fácil de explicar, pois as máquinas deste ramo industrial trabalham normalmente 24 horas, só podendo parar para manutenções bem dirigidas, segundo estudos da ABRAMAM (1998).

MONCHY (1989) comenta da necessidade da manutenção trabalhar nas causas das falhas buscando ações para eliminá-las ou, pelo menos, minimizá-las. Isso se faz fundamental devido ao custo da falha, sendo que várias ferramentas, métodos e técnicas foram desenvolvidas visando suprir essas necessidades, bem como alguns processos idealizados a fim de atuar especificamente na garantia da disponibilidade e confiabilidade.

Em virtude dessa característica estratégica da função manutenção diante de um processo de produção contínua, NAGAO (1998) sugere dez itens globais a serem observados na proposição de uma política de manutenção:

1. A prevenção de falhas é a base da manutenção.

2. É fundamental a utilização da engenharia de manutenção e dos métodos operacionais para a melhoria de performance.

3. É necessária a aplicação de critérios de manutenção adequados.

4. O uso do planejamento e programação de serviços para otimização dos recursos é indispensável.

5. Medir para gerenciar.

6. A formação, treinamento e desenvolvimento dos profissionais de manutenção deve ser uma constante.

7. A Qualidade Total deve ser um fator permanente, ou seja, todas as políticas e diretrizes devem estar incorporadas nas ações do dia-a-dia.

8. Responsabilidade e busca de soluções conjuntas entre a manutenção e a operação.

9. Rigor e precisão são premissas básicas, principalmente quando relacionadas com a segurança, higiene e meio ambiente.

10. A constante busca pela inovação como fator de sucesso.

Ainda, dando enfoque às paradas planejadas esclarece que devido às inúmeras atividades realizadas nesses momentos, a quantidade de pessoas envolvidas e aos prazos estabelecidos, as indústrias de processos contínuos devem ter uma área 
que coordene continuamente estes eventos.

Normalmente, esta atividade é de responsabilidade da equipe de planejamento e programação de manutenção, com o apoio da engenharia de manutenção. Estas, devem ser o alicerce para o sucesso na realização de Paradas Setoriais (PS's) e Gerais (PG's), bem como intervenções em momentos de oportunidade (MO).

As paradas planejadas configuram-se como um diferencial tecnológico no setor papeleiro, pois seu sucesso resulta em uma maior confiabilidade operacional e num representativo aumento da competitividade, alicerçadas em uma linguagem universal: "redução e otimização das perdas e custos envolvidos no processo". No entanto, para que esse sucesso seja alcançado, muito planejamento e tempo são necessários, bem como metas e formas de controle bem definidas.

Contudo, observa-se que o monitoramento contínuo dos equipamentos e sistemas, as intervenções em MO e as paradas planejadas (PS's ou PG's) são as principais ações de uma "política de manutenção" adequada às indústrias do setor papeleiro, a qual deve ter como fundamento a valorização das pessoas, o investimento na gestão da qualidade (do processo e do produto) e do conhecimento. Como metas, destacam-se o aumento contínuo da produtividade e disponibilidade, através do gerenciamento da confiabilidade da planta fabril.

\subsubsection{Práticas básicas de manutenção}

A prática dos vários tipos de manutenção, de forma isolada e sem critérios não garantem o sucesso da função manutenção no processo, que pode ser obtido através da aplicação de uma política de manutenção que direcione esforços de forma adequada para cada equipamento e instalação, sempre voltada à confiabilidade e à disponibilidade operacional.

Segundo PINTO \& XAVIER (1999), os vários tipos de manutenção existentes são caracterizados pela maneira como é feita a intervenção nos equipamentos, sistemas ou instalações. Buscando uma caracterização mais objetiva e direcionada dos diversos tipos de manutenção à visão da equipe de manutenção no contexto desse trabalho, algumas práticas básicas são sintetizadas a seguir: 


\section{Manutenção Corretiva:}

Essa prática é aplicada na correção de uma falha ou de um desempenho menor do que o esperado, ou seja, não é, necessariamente, uma manutenção de emergência. A ação principal nesse tipo de manutenção é "corrigir" ou "restaurar" as condições de funcionamento de um equipamento ou sistema, podendo assim ser dividido em duas classes: manutenção corretiva planejada e não planejada.

É lógico dizer que, cada vez mais, a utilização da corretiva planejada apresenta enorme vantagem em detrimento da corretiva não planejada, caracterizada pela correção da falha de maneira aleatória, a partir de um fato já ocorrido.

\section{Manutenção Preventiva:}

É realizada com o objetivo de "reduzir" ou "evitar" a falha ou queda no desempenho, obedecendo um plano previamente elaborado e baseado em intervalos de tempo normalmente definidos pelo fabricante. Esse tipo de manutenção busca evitar a ocorrência de falhas através da prevenção, e é imperativa para determinados sistemas ou componentes, devido ao fator segurança se sobrepor aos demais.

Como normalmente é necessária a retirada do equipamento ou sistema de operação para este tipo de manutenção, independente de sua performance no momento, vários questionamentos são levantados pela equipe de operacional. Outro ponto negativo com relação desse tipo de intervenção é a possibilidade da introdução de defeitos não existentes no equipamento.

\section{Manutenção Preditiva:}

É a atuação com base na variação nos parâmetros de "condição" ou “desempenho", cujo acompanhamento obedece um programa. Também é conhecida por manutenção sob condição ou manutenção com base no estado do equipamento.

Esse tipo de prática é tida como a primeira grande quebra de paradigma na manutenção, e é fortalecida com o desenvolvimento de equipamentos que permitem avaliações confiáveis das instalações e sistemas operacionais em funcionamento, privilegiando a disponibilidade operacional.

"No tocante à produção, a Manutenção Preditiva é a que oferece melhores resultados, pois intervém o mínimo possivel na planta..." (PINTO \& XAVIER, 1999:39). 
Para sua aplicação adequada, uma equipe de planejamento bem treinada e disciplinada é fundamental, pois mais que medir é preciso analisar constantemente os resultados e formular diagnósticos precisos.

\section{Manutenção Detectiva:}

Normalmente, é aplicada em sistemas de proteção, buscando "detectar" falhas ocultas ou não-perceptíveis ao pessoal de área.

$\mathrm{Na}$ indústria papeleira, essa prática torna-se indispensável devido a utilização de sistemas como os de shut-down ou trip, que têm a função de garantir a segurança de um processo quando este sai de sua faixa de operação segura.

Os componentes desses sistemas também apresentam falhas, podendo acarretar dois problemas: a não-atuação e a atuação indevida dos mesmos. $\mathrm{Na}$ ocorrência de uma dessas situações certamente haverá perdas de produção, paradas emergenciais e riscos quanto a segurança operacional, pessoal e ambiental.

Entretanto, têm-se outras abordagens desses tipos de manutenção. NAGAO (1998), fala sobre três tipos de intervenções de manutenção: manutenção corretiva ou acidental (após falhas ou quebras), manutenção preventiva sistemática (revisões periódicas) e manutenção preventiva sob condição (a preditiva).

KRÖNER (1999), descreve os principais tipos de manutenção relacionando-os às técnicas da qualidade aplicadas nas empresas japonesas e, além das práticas já relacionadas, incluí: Manutenção Produtiva Total (TPM), onde está englobada a manutenção preventiva; e manutenção autônoma, que reforça os conceitos da realização de pequenos reparos de rotina por parte dos operadores.

Quanto ao futuro da utilização desses tipos de manutenção, PINTO \& XAVIER (1999) apresentam algumas tendências:

- a redução do uso da corretiva não planejada e preventiva;

- aumento da utilização da corretiva planejada, principalmente quando aliada a preditiva;

- uma utilização cada vez maior da preditiva, impulsionada pelos avanços na área eletrônica;

- uma crescente importância da detectiva, em virtude da maior automatização das plantas e utilização de microprocessadores. 


\subsubsection{Engenharia de manutenção}

No enfoque deste trabalho, a Engenharia de Manutenção (EM) é praticada por uma equipe que tem como principais responsabilidades à busca incessante pelas causas básicas das falhas ou inconveniências, modificação de situações de mau desempenho, analise dos problemas crônicos, aperfeiçoamento de procedimentos, além do apoio à gestão da equipe. Em essência, implica na constante procura e aplicação de técnicas modernas na gestão e planejamento da manutenção.

"No momento em que a estrutura de manutenção desta planta estiver utilizando para análises, estudos e proposição de melhorias todos os dados que o Sistema de Preditiva colhe e armazena, estará praticando Engenharia de Manutenção..." (PINTO \& XAVIER, 1999: 43).

$\mathrm{Na}$ verdade, esta prática representa uma mudança cultural da equipe de manutenção, e é encarada como a segunda quebra de paradigma na Manutenção.

BRANCO FILHO (2000), coloca a engenharia de manutenção como um órgão consultivo fundamental que constitui o sistema de controle de manutenção para corrigir e melhorar a gestão apoiando a equipe de planejamento, através do aperfeiçoamento das técnicas e procedimentos utilizados, do benchmarking das melhores práticas, do desenvolvimento de novas idéias e da implementação de uma política de manutenção adequada.

\subsubsection{Manutenção centrada em confiabilidade}

A introdução dos conceitos de disponibilidade e confiabilidade no contexto da manutenção formam as bases da Reliability-Centred Maintenance $(R C M)$, em português "Manutenção Centrada em Confiabilidade". Segundo NAGAO (1998), a disponibilidade é o percentual de tempo considerado em que um equipamento ou sistema funciona com sucesso, ou seja, dentro dos padrões esperados. Já a confiabilidade de um equipamento ou sistema é a probabilidade de sua operação com sucesso por um período de tempo e sob condições previamente especificadas. 
A $R C M$ é um processo usado para determinar o que deve ser feito para assegurar que os equipamentos ou sistemas continuem a fazer o que os usuários querem que ele faça no seu contexto operacional presente, ou seja, atua na garantia da "função" dos equipamentos (MOUBRAY, 2000). Pode-se dizer então que a $R C M$ focaliza tratar a confiabilidade dos ativos fixos de uma empresa a fim de garantir a disponibilidade de sua planta fabril e, dessa forma manter a estabilidade do processo.

Enfocando a gestão, PINTO \& XAVIER (1999) abordam a $R C M$ como uma ferramenta que permite a aplicação dos tipos de manutenção de uma forma coerente e sistematizada, configurando-se como um suporte à decisão gerencial. Tecnicamente, está fundamentada e estruturada no estudo e atuação baseados nos padrões de falha caracterizadas pelas "curvas de falha".

Neste sentido, MOUBRAY (2000) definiu vários conceitos, como por exemplo: funções e padrões de desempenho, falhas funcionais, modos e efeitos da falha, conseqüências da falha e tarefas pró-ativas. Para a implementação da $R C M$, coloca três aspectos como fundamentais: (1) a formação de uma equipe multidisciplinar de estudos, (2) a definição de quais os equipamentos ou sistemas serão submetidos ao processo de revisão $R C M$, e (3) uma aplicação inicial piloto da ferramenta, com a finalidade de garantir a utilização correta da mesma em um caso real.

Finalmente, o mesmo autor relaciona os principais benefícios da $R C M$ :

- maior segurança e proteção ambiental;

- melhoria contínua do desempenho operacional;

- maior efetividade do custo de manutenção;

- vida útil mais longa de itens dispendiosos;

- um banco de dados de manutenção completo;

- maior compartilhamento dos problemas de manutenção;

- elevado grau de motivação das pessoas;

- geração de senso de equipe.

O desenvolvimento técnico-profissional das pessoas é o principal destaque na aplicação desse processo, difundindo uma visão global voltada a máxima disponibilidade e confiabilidade operacional. 


\subsubsection{Gerenciamento, planejamento e controle da manutenção}

Atualmente, a equipe de manutenção deve ser vista como fundamental dentro de uma organização fabril. A amplitude de suas ações e o impacto sobre a produção e o negócio são definitivas para o sucesso ou fracasso no mercado globalizado e altamente competitivo.

Aspectos como o gerenciamento, planejamento e controle, até então direcionados simplesmente à programação e execução das atividades de manutenção, bem como à medição da eficiência das equipes e ações de manutenção tiveram uma mudança radical de enfoque, principalmente com o suporte das equipes de engenharia de manutenção.

Isso torna-se sensível quando da busca pelas definições da "visão" e da "missão" da manutenção que, na atualidade, têm conotações bem mais amplas e estratégicas. NAGAO (1998) esclarece que a visão da manutenção deve ser fruto de uma reflexão da equipe de manutenção sobre seus objetivos e metas diante os novos paradigmas dessa função, buscando a excelência e uma contribuição mais efetiva para a organização na face a competitividade mundial. É importante também que esta visão seja compartilhada por todos os colaboradores da área, haja vista a necessidade de uma integração com as políticas e diretrizes da organização.

Com o surgimento dos conceitos de qualidade, produtividade $\mathrm{e}$ confiabilidade, e dentro dessa nova visão da função manutenção, a missão dessas equipes tornou-se muito mais que manter, restabelecer ou garantir a disponibilidade dos equipamentos ou instalações, pois fatores como a interação contínua com as outras áreas da organização e o impacto de suas ações além dos limites da planta passaram a ter um papel fundamental. Neste sentido, MOUBRAY (2000) coloca que na atualidade a função manutenção afeta todos os aspectos do negócio: segurança, integridade ambiental, eficiência energética, qualidade dos produtos e dos serviços, e não somente a disponibilidade da planta e seu custo.

Para PINTO \& XAVIER (1998: 16), hoje a missão da manutenção é:

"Garantir a disponibilidade da função dos equipamentos $e$ instalações de modo a atender a um processo de produção e a preservação do meio ambiente, com confiabilidade, segurança e custos adequados." 
Assim, em virtude dos aspectos estratégicos e éticos que englobam a manutenção na atualidade, à equipe de planejamento e controle cabe gerenciar todas as atividades afins dos fornecedores internos para promover a satisfação do cliente principal, a operação, a fim de que esta tenha as instalações de acordo com as necessidades da organização para atingir as metas pré-estabelecidas. Como exemplos destes fornecedores, podem ser citados a engenharia, a área de suprimentos de materiais, as oficinas, terceiros em geral, entre outros.

No entanto, para tornar-se uma área central de informações, onde todas as ações das partes são avaliadas, gerenciadas, planejadas e executadas, da forma mais eficiente e eficaz possível, a manutenção teve de evoluir na utilização de várias ferramentas e técnicas de gestão, bem como no desenvolvimento técnico e cultural de seus profissionais. Diante desses fatores, podemos destacar que para o atendimento dessas diretrizes, algumas características e atividades são fundamentais no gerenciamento da manutenção:

- a geração de relatórios gerenciais, com indicadores que proporcionem uma avaliação das atividades de manutenção e permitam o estabelecimento de metas e a correção de distúrbios sem maiores conseqüências;

- o estudo das formas de atuação da manutenção e a emissão dos programas para as ações na planta, sejam elas corretivas, preventivas, preditivas, inspeções etc.;

- a gestão das paradas planejadas e de oportunidade;

- a gestão da equipe e de cada profissional;

- a promoção do contínuo desenvolvimento, atualização e capacitação profissional;

- e a interface com a equipe de operação da planta e com as áreas afins.

A elaboração de relatórios consistentes e de qualidade, a utilização de sistemas informatizados e uma postura pró-ativa também são indispensáveis. Segundo TAVARES (1999), para uma avaliação efetiva da gestão da manutenção são necessários relatórios compostos por: 
- Índices de classe mundial - tempo médio entre falhas, tempo médio para reparo, tempo médio para falha, disponibilidade de equipamentos, custo de manutenção por faturamento e custo de manutenção pelo valor de reposição.

- Índices para gestão de equipamentos - tempo médio entre manutenções preventivas, tempo médio para intervenções preventivas e backlog de serviços de manutenção.

- Banco de dados com o histórico dos equipamentos e instalações.

- Índices para gestão de custos.

- Índices para gestão da mão de obra, entre outros.

Ainda, destaca que um dos pontos chaves do gerenciamento da manutenção é o planejamento e a programação dos serviços de forma eficiente, haja vista que sem uma estruturação adequada para planejar, programar e executar os serviços, torna-se difícil a otimização dos recursos. Buscando-se atuar nesse sentido, deve haver a utilização sistemática de ferramentas estatísticas para o acompanhamento e monitoramento da performance das atividades de planejamento, programação, controle e execução.

Focando as paradas planejadas, o autor citado coloca que em indústrias de processos contínuos, um módulo de planejamento de paradas disciplinado e atuante é fundamental, devido a esses eventos significarem um período intenso de atividades com centenas ou até milhares de pessoas trabalhando em conjunto dentro de um prazo bem definido.

Nesse contexto, na busca pelo aperfeiçoamento da ação dos profissionais de manutenção, várias ferramentas e técnicas foram colocadas a disposição das equipes de manutenção. Os encontros multidisciplinares para análises das falhas, anomalias, problemas e riscos diante uma situação de planejamento, simulação, emergência ou exercícios de treinamento tornaram-se essenciais e indispensáveis no dia-a-dia dos profissionais das áreas produtivas das indústrias.

A aplicação dessas ferramentas visa a estudar, a partir de vários enfoques, características como: segurança operacional, riscos potenciais durante as intervenções, agressão ao meio ambiente, otimização dos custos, e os problemas e perdas identificadas no processo. Focando a busca por uma atuação mais efetiva e 
estratégica, têm-se a seguir algumas das formas de análises mais utilizadas na atualidade pelas equipes de manutenção.

\subsubsection{Análise de Árvore de Falhas (FTA)}

Para HELMAN \& ANDERY* apud PASQUA (1999: 25), a FTA Fault Tree Analysis (Análise de Árvore de Falhas) é configurada como:

“...um método sistemático e padronizado, capaz de fornecer bases objetivas para funções diversas tais como a análise de modos comuns de falhas em sistemas, justificação de alterações em sistemas e outras aplicações..."

Em linhas gerais, esta análise tem início a partir de uma falha ocorrida ou problema identificado, fato denominado evento de topo, e desenvolve-se com a elaboração de uma seqüência de outros fatos capazes de conduzir a origem do tal evento. O modelo gráfico resultante deste exercício é chamado de árvore de falha, e permite ilustrar de uma maneira simples o encadeamento dos diferentes eventos que dão como resultado o evento de topo.

A análise termina quando da identificação de eventos ou situações denominadas limite de resolução, ou seja, quando são apontadas as causas básicas para as quais é possível a elaboração de um plano de ação visando o bloqueio das mesmas (eventos de topo). O raciocínio utilizado nessas análises é caracterizado com sendo "de cima para baixo".

Em relação aos reflexos na utilização, os mesmos autores discutem que o contínuo treinamento e desenvolvimento dos envolvidos, tanto profissional como técnico, a constituição de registros confiáveis dos procedimentos de manutenção da empresa, e a eliminação dos problemas crônicos tornam esse tipo de análise muito proveitosa, satisfatória e eficiente.

\footnotetext{
* HELMAN, H.; ANDERY, P.R.R. (1995). Análise de Falhas (Aplicação de Métodos de FMEA - FTA). Belo Horizonte, Fundação Chistiano Ottoni apud PASQUA, M. C. (1999). Desenvolvimento de uma sistemática para padronização e gerenciamento da programação da manutenção a partir de conceitos da qualidade. 128p. Dissertação (Mestrado) - Escola de engenharia de São Carlos, Universidade de São Paulo.
} 


\subsubsection{Análise de Modo e Efeito de Falha (FMEA) e Análise das Causas Raízes da Falha $($ RCFA)}

Segundo PINTO \& XAVIER (1999), FMEA (Failure Modes and Effects Analysis, em português Análise de Modo e Efeito de Falha) é um sistema lógico e organizado que hierarquiza as falhas potenciais e fornece as recomendações para as ações preventivas, através de um processo formal que utiliza especialistas para analisar as falhas e propor soluções. Geralmente é utilizada como um degrau para o estabelecimento do programa de RCFA (Root Cause Failure Analysis, em português Análise das Causas Raízes da Falha).

Existem três níveis de FMEA: projeto, processo e sistema. Como o enfoque deste trabalho é manutenção da planta fabril, será destacada a FMEA no processo, pois esta focaliza como o equipamento é mantido e operado. Para a aplicação desta técnica é sugerido um grupo multidisciplinar e que tenha engenheiros e técnicos tanto de manutenção como de operação.

Basicamente, durante essas análises cinco questões são exploradas:

1. Que tipo de falhas são observadas?

2. Que partes do sistema são afetadas?

3. Quais são os efeitos da falha sobre o sistema?

4. Qual é a importância da falha?

5. Como prevení-la?

A partir das respostas obtidas, planos de ações são traçados para eliminar ou corrigir os problemas e, de acordo com a frequiência e a gravidade das falhas, é feita uma priorização das ações corretivas (PINTO \& XAVIER, 1999).

As principais vantagens dessas análises são: a complementaridade de conhecimentos, as decisões compartilhadas e a maior precisão nos resultados.

A RCFA é recomendada, pelos mesmos autores, para análise de problemas crônicos, que podem custar muito mais do que a correção da falha, devido a sua alta freqüência.

"Problemas não devem se tornar crônicos; caso isso aconteça, não se está fazendo uma boa gestão da manutenção." (PINTO \& XAVIER, 1999: 96). 
Aqui também, a formação de grupos multidisciplinares e multifuncionais é o ideal para a aplicação, e a análise realizada é baseada no questionamento "Por quê?". A técnica recomendada é que se faça tantas vezes essa pergunta até que a questão não faça mais sentido, ou seja, até que a causa raiz seja identificada.

Faz-se importante observar que toda análise, seja ela de FMEA ou RCFA deve ser devidamente documentada e registrada, para servir de referência futura e constar no histórico do equipamento.

\subsubsection{Análises de Problemas (APP) e Riscos Potenciais (ARP)}

Segundo KEPNER \& TREGOE (1991), a Análise de Problemas Potenciais foi desenvolvida baseada em um dos quatro processos racionais básicos para utilização e troca de informações entre as pessoas, no que se refere a solução de problemas organizacionais.

Os quatro padrões de raciocínio resultantes não se alteraram substancialmente desde o aparecimento da raça humana: (1) avaliar e esclarecer; (2) estabelecer uma relação causa e efeito; (3) fazer escolhas; e (4) antecipar-se ao futuro. Este último fundamenta o processo das APP, tido como um processo extremamente sistemático.

"A Análise de Problemas Potenciais é um procedimento que nos habilita caminhar para dentro do futuro, ver o que pode conter $e$ então retornar para o presente para tomar a ação agora (...) é um padrão de raciocínio que nos capacita a mudar e aprimorar o futuro (...) é um ato voluntário de prudência." (KEPNER \& TREGOE, 1991:131).

Com isso, nota-se a estreita ligação desta ferramenta com a manutenção no dia-a-dia, principalmente para a análise dos problemas que são identificados nos equipamentos e instalações a partir de pontos cuja vulnerabilidade é aparente aos olhos dos profissionais que atuam diretamente na planta.

Para aplicação, inicialmente devem ser feitas duas perguntas básicas: "O que poderia dar errado?" e “O que podemos fazer a respeito agora?". Depois, quatro atividades fornecem a estrutura para o desenvolvimento da análise, bem como para seu registro: 
- Identificação das áreas vulneráveis.

- Identificação de problemas potenciais específicos dentro dessas áreas.

- Identificação das causas prováveis desses problemas e a definição de ações para evitar sua ocorrência.

- Identificação de ações contingentes para minimizar os efeitos das falhas, nos pontos cuja total prevenção é impossível.

Por fim, caracterizando os momentos adequados para a utilização desta ferramenta, os mesmos autores colocam que isto deve ocorrer sempre que a experiência e a intuição dos envolvidos disserem que alguma coisa poderá dar errado no futuro, e o custo desse "dar errado" poderá ser representativo para o negócio.

Se comparada a utilização da APP, a Análise de Riscos Potenciais possui os mesmos fundamentos, entretanto é aplicada em intervenções planejadas para grandes reparos, que envolvam paradas ou reduções da produção ou alguma atividade que justifique maiores cuidados (DOVICO, 2000).

Esta técnica consiste na identificação dos caminhos críticos e análise de todos os fatores que possam contribuir para um desvio no planejamento inicial de uma intervenção, em relação ao tempo de duração total estimado a priori. A análise é realizada antecipadamente ao evento baseada nas seguintes atividades:

- identificar os fatores de risco potenciais para a intervenção;

- traçar planos de ação para evitar os riscos apontados;

- definir responsáveis e prazos para as ações traçadas.

Para uma análise bem fundamentada e efetiva, é recomendável a formação de grupos compostos por todos os profissionais envolvidos com o evento, ou seja: técnicos de manutenção de todas as especialidades, planejadores, supervisores de manutenção e operação, profissionais da área de segurança, representantes dos provedores de serviços contratados, especialistas, pessoas da área de suprimentos, administrativa etc. 


\subsection{A Qualidade Total (QT)}

No inicio da década de 50, Deming, Juran e Ishikawa foram os pioneiros da filosofia da Qualidade Total (QT), revolucionando os padrões de mercado até então existentes. Eles conseguiram perceber a crescente importância da função qualidade nas empresas e identificaram alguns fatores essenciais para o bom uso de ferramentas que podem levar a excelência na Qualidade, como: o comprometimento a longo prazo da alta administração para o objetivo de melhorias contínuas, o investimento em treinamento e educação, e a mudança dos métodos gerenciais. Face a essas necessidades, lançaram suas teorias sobre as estratégias adotadas na busca pela melhoria da qualidade dos produtos e processos.

A partir da década de 70, surgiram programas como o "Zero Defeitos" (ZD) e o uso da "Função Perda de Qualidade" para avaliar os custos pela não qualidade dos produtos e, também, uma série de ferramentas e metodologias foram desenvolvidas para melhoria da qualidade. Essa explosão da filosofia da QT resultou, após os anos 80, no surgimento de diversos programas de gestão - Total Quality Manangement, TQM, ou Total Quality Control, TQC (FAESARELLA; SACOMANO \& CARPINETTI, 1988).

Segundo CAMPOS (1992), onze tópicos definem o conceito do TQM:

1. Orientação pelo cliente.

2. Qualidade em primeiro lugar.

3. Ação orientada por prioridades.

4. Ação orientada por fatos e dados.

5. Controle de processos.

6. Controle da dispersão dos dados.

7. Próximo processo é seu cliente.

8. Controle a montante.

9. Ação de bloqueio as causas dos problemas.

10. Respeito pelo empregados como ser humano.

11. Comprometimento da alta direção.

Enfocando a manutenção, TAVARES (1999) coloca que a QT visa a busca do atendimento das necessidades dos clientes (internos e externos) através da 
maximização da confiabilidade dos produtos ou serviços, atendimento a todos os requisitos propostos, recompensa pelo investimento e isenção do desgaste provocado pelas reclamações quanto a não conformidade, baseada em uma forma de gestão voltada a liberdade e ao estímulo do potencial de todos os profissionais.

Com isso, paralelamente a evolução da manutenção e suas inovações específicas, a partir da década de 80, com o surgimento de várias filosofias e técnicas de gestão voltadas à qualidade e à produtividade, aplicadas até então com grande êxito nas indústrias orientais, surgiram idéias que se somaram as necessidades da emergente função manutenção. A sua infiltração no mercado ocidental fez com que o consumidor passasse a considerar alguns fatores antes desapercebidos como fundamentais nos produtos a adquirir, fazendo com que as empresas observassem esses novos fatores e considerassem a qualidade como uma necessidade para se manterem competitivas (TAVARES, 1999).

Na visão de PINTO \& XAVIER (1998), com a introdução dos conceitos de QT, houve a busca pela chamada "cultura de mudanças" nas empresas, a qual fez necessária a difusão dos conceitos da qualidade e produtividade, direcionados a redução das perdas e desperdícios, tanto na organização como em seu processo produtivo. Iniciou-se assim uma transformação organizacional que visa mudanças profundas na forma de pensar e agir das pessoas que compõem a organização, pois mais do que técnicas e tecnologia, tornou-se fundamental que todos tenham a mesma visão, objetivos e hábitos.

Esses fatores tornaram ainda mais iminente a crescente e necessária modificação na forma de atuar das equipes de manutenção e em seu gerenciamento, principalmente quando considerada como um elo de ligação das ações dos vários subsistemas de uma organização. Assim, uma variedade de instrumentos gerenciais foram colocados a disposição do homem de manutenção, entre eles: $5 S$, Kaizen, TPM e Ciclos PDCA e SDCA.

Do ponto de vista técnico e direcionado para atividades operacionais e de manutenção, em 1987 surgiu a International Organization for Stadardization (ISO), uma federação mundial de organismos de normatização que homogeneizou e reuniu requisitos dispersos em diversas normas sobre qualidade em uma única série. As normas $I S O$ objetivam descrever e padronizar os elementos básicos através dos quais 
os sistemas da qualidade podem ser implementados e certificados a nível global (TAVARES, 1999).

Para um melhor entendimento do enfoque e da importância destas filosofias, ferramentas, programas, técnicas e normas voltadas à qualidade no ambiente da manutenção, e indispensáveis para a implementação de uma política de manutenção efetiva, faz-se a seguir algumas considerações sobre elas.

\subsubsection{A prática do 5S (Housekeeping)}

O $5 S$ é uma prática desenvolvida inicialmente no Japão e depois ocidentalizada, onde ficou conhecida como Housekeeping (cuidar da casa). Ela é baseada no ensinamento de princípios educacionais, representados por cinco atividades seqüenciais e cíclicas iniciadas pela letra "S", quando pronunciadas em japonês: Seiri, Seiton, Seiso, Seiketsu e Shitsuke (RIBEIRO, 1994).

Sintetizando várias denominações, essas cinco palavras significam, respectivamente: Organização, Arrumação, Limpeza, Padronização e Disciplina. Esta prática provoca mudanças diretamente no ambiente de trabalho e nas atitudes das pessoas, sendo por isso considerada um processo educacional utilizado atualmente por muitas empresas como um ferramenta indispensável na implementação e consolidação da gestão pela QT.

Além disso, é um programa direcionado a todos os ambientes em que há carências ou distúrbios educacionais de seus usuários, e isso o faz tão necessário nas empresas instaladas no Brasil, que buscam imprimir uma "cultura de mudanças" nas pessoas a partir do comportamento grupal. Normalmente, em países desenvolvidos ocorre o contrário, a formação dos hábitos e do comportamento das pessoas se dá durante sua educação, partindo do conhecimento para o comportamento grupal.

Segundo RIBEIRO (1994), o $5 S$ é um programa comportamental e deve ser implantado de forma sistematizada, e alinhado com uma diretriz empresarial. Necessita ser conduzido com profissionalismo, disciplina e comprometimento de todos os líderes da organização. A principal característica do $5 S$ é sua simplicidade, e por isso deve ser praticado com muito rigor e constância, para que não seja esquecido 
ao longo do tempo.

Enfatizando a importância desta ferramenta, tem-se:

"O $5 S$ promove o aculturamento das pessoas a um ambiente de economia, organização, limpeza, higiene e disciplina, fatores fundamentais à elevada produtividade." (CAMPOS, 1998:26)

Dando enfoque a manutenção, PINTO \& XAVIER (1988) descrevem o $5 S$ como uma prática básica da manutenção moderna, utilizada nas empresas visando aspectos macro como: melhoria da qualidade, redução de custos, melhoria de atendimento ao cliente, moral do grupo e aumento da segurança pessoal e das instalações.

Por fim, buscando esclarecer exatamente o papel do $5 S$ dentro de uma organização, RIBEIRO (1994: 25) escreve:

"O $5 S$ está longe de ser uma panacéia (remédio para todos os males), sendo desaconselhável a sua implantação com a expectativa de solucionar problemas em ambientes de conflitos. $E$ um processo simples, com resultados imediatos e duradouros para o homem (dentro e fora da empresa), para a empresa, para os clientes e para o meio-ambiente. Enfim, o 55 é a Base da Qualidade Total."

\subsubsection{A Metodologia Kaizen}

Se a prática do $5 S$ é considerada como a base para a QT, a metodologia Kaizen pode ser definida como um ideal comum nesta busca. Sua filosofia afirma que o nosso modo de vida, seja no trabalho, na sociedade ou em casa, merece ser constantemente melhorado (IMAI, 1992).

Kaizen é uma técnica japonesa que significa "mudança para melhor", tradução que vem da união de duas palavras: KAI (mudança) e ZEN (melhor). De forma mais ampla, esta técnica significa de fato o contínuo melhoramento, envolvendo todos dentro de uma organização: a alta administração, os gerentes, os operários etc.

Segundo IMAI (1992), o Kaizen reúne, em baixo de um "guarda-chuva", todos os processos e sistemas desenvolvidos para a melhoria da qualidade e produtividade (TQC, CCQ, TPM, JIT, ZD, Kanban, entre outros), gerando um 
pensamento orientado para o processo, visando melhoramentos que levem a obtenção de resultados cada vez melhores pela organização.

As principais finalidades desta filosofia são eliminar tudo que não agrega valor ao produto e reduzir os desperdícios, dentro de uma forma de gestão que estimule em todos uma atitude de questionamento e a mente aberta para o melhoramento constante, com base no trabalho de equipe e na cooperação. Para isso, são utilizadas ferramentas e métodos para maximizar a qualidade, a eficiência, e minimizar o esforço.

Finalmente, concretizando sua amplitude educacional e organizacional, o mesmo autor define que o conceito prega que todos, não importa o cargo que ocupam, devem admitir abertamente quaisquer erros que tenham cometido ou falhas que existam no seu serviço e tentar fazer melhor da próxima vez, baseado na máxima de que "o progresso é impossível sem a habilidade de admitir erros".

Na visão de ANHESINE (1999), a metodologia Kaizen é uma das mais utilizadas atualmente pelos gestores do setor de manutenção industrial, e tem como uma de suas principais contribuições auxiliar no gerenciamento das atividades de manutenção. Sua estratégia é voltada para manter e melhorar os padrões de trabalho através de melhoramentos pequenos e graduais.

Assim, na manutenção esta filosofia é difundida no sentido de aguçar nos seus profissionais o senso de permanente questionamento e a necessidade de fazer melhor, ou seja, produzir sempre mais com cada vez menos.

\subsubsection{Manutenção Produtiva Total (TPM)}

Diante das inúmeras abordagens de Total Productive Maintenance $(T P M)$ existentes, busca-se a seguir uma abordagem simples num enfoque voltado à manutenção.

O TPM pode ser considerado como uma evolução natural da manutenção preventiva, como abaixo:

- 1950 - manutenção preventiva

- 1957 - manutenção com introdução de melhorias 
- 1960 - prevenção de manutenção na fase de projeto

- 1970 - Manutenção Produtiva Total (TPM)

Nas últimas décadas, com a introdução de conceitos da qualidade, produtividade, competitividade e confiabilidade, as empresas viram à necessidade de eliminar desperdícios, melhorar o desempenho dos equipamentos, reduzir as perdas de produção por quebras, modificar a sistemática de trabalho e redefinir o perfil e habilidades de seus funcionários (PINTO \& XAVIER, 1998).

No enfoque oriental, NAKAJIMA (1989) escreve que o TPM significa a reformulação da postura, tanto dos homens como das máquinas, ou seja, sua abrangência é por toda a organização, visando a reformulação para uma nova empresa. Com isso, objetiva promover a integração da manutenção do sistema produtivo tanto nos aspectos administrativos como operacionais.

Quanto a aplicabilidade no desenvolvimento desse processo com sucesso, o mesmo autor alerta para a necessidade de cinco alicerces essenciais:

1. Incorporação de melhorias específicas e individualizadas nos equipamentos e sistemas;

2. Estruturação para condução da manutenção voluntária ou autônoma por parte dos operadores;

3. Estruturação do setor de manutenção para a condução da manutenção planejada (a EM);

4. Capacitação técnica e busca de novas habilidades tanto para os profissionais da produção como da manutenção;

5. Estruturação para controle dos equipamentos já na fase inicial de funcionamento.

Basicamente, a atuação do TPM está voltada para a eliminação de seis grandes perdas identificadas nos processos: perda por quebras, perdas por mudança de linha, perda por operação em vazio e pequenas paradas, perdas por redução da produção, perdas por produtos defeituosos e perdas por queda no rendimento.

Como maior enfoque deste programa, a "otimização dos recursos" é perseguida através de alguns fatores: maximização do rendimento operacional, enfoque sistêmico global, integração total, atividade voluntária para melhorias, e o envolvimento em todos os níveis, desde a alta gerência até o operacional. 
Com isso, nota-se que a manutenção está estreitamente ligada a essa filosofia, principalmente por ter como meta constante a eliminação de perdas através das ações sobre as falhas e problemas potenciais. Além disso, outro conceito que demonstra esta cumplicidade é o da "Quebra Zero" (que prega que a máquina não pode parar durante o período em que foi programada para operar), haja vista a máxima que diz que "a manutenção existe para que não haja manutenção".

À nível organizacional, TPM prega que o perfil dos profissionais deve ser adequado através de treinamentos e programas de capacitação, buscando redefinir algumas funções básicas, como: operadores, voltados a realizar atividades de manutenção de forma espontânea; técnicos de manutenção, orientados para tarefas na área de mecatrônica; e engenheiros, trabalhando na concepção de equipamentos que “não exijam manutenção".

Finalmente, caracterizando alguns resultados da implementação desse processo, TAVARES (1996: 55) esclarece:

"Como resultados tangíveis da aplicação do TPM, destacam-se a redução de quebras, o aumento do faturamento (em função do aumento da disponibilidade), o aumento da vida útil, a redução de custos de manutenção (em função de sua execução sob controle) $e$ o tempo gasto nas intervenções. Como resultados intangíveis (...) encontra-se a confiança, o conforto, a tranqüilidade e o sentido de propriedade ("de minha máquina, cuido eu”)."

\subsubsection{O gerenciamento da rotina (Ciclos $P D C A$ e $S D C A)$}

A atividade de manutenção nada mais é do que um dos processos de uma organização e, como todo processo, precisa ser gerenciado. Gerenciar processos é de uma forma simples planejar, acompanhar a execução, verificar se há desvios e fazer as correções quando necessário, ou seja "exercer o controle".

Neste contexto, segundo CAMPOS (1992) o Ciclo PDCA (Plan-DoCheck-Action) é um método para a "prática do controle", e é composto por quatro fases básicas - planejar, executar, verificar e atuar corretivamente, como mostra a figura 3.1 . 


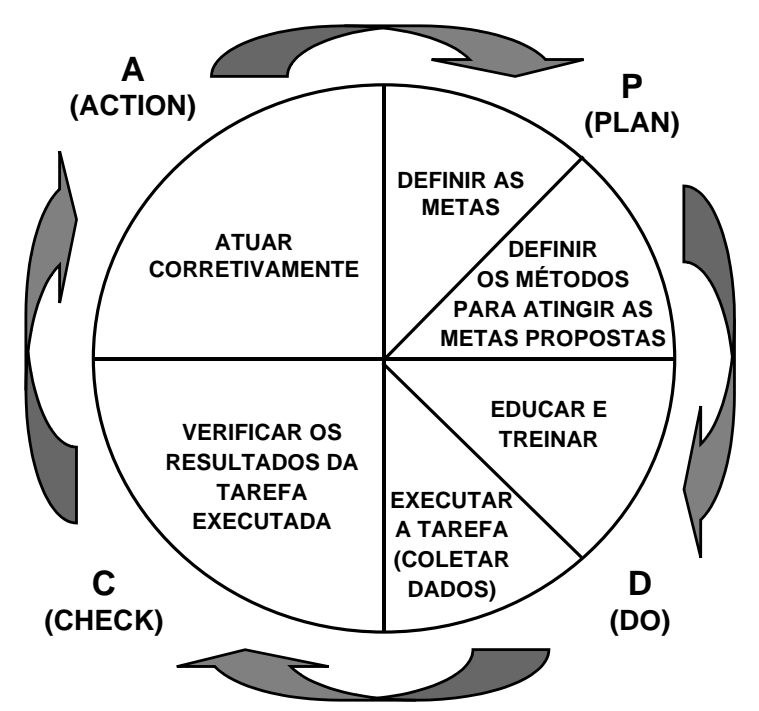

Figura 3.1 - Ciclo PDCA de controle de processos, CAMPOS (1992:30).

Na QT esse método é utilizado como uma forma de gestão, um caminho para atingir metas. Existem dois tipos de meta: as metas para manter e as metas para melhorar.

Para manter as metas pré-definidas, ou seja, para atingir os padrões já estabelecidos é utilizado o chamado Ciclo SDCA (S para "Standard" ou Padrão). Já a meta para melhorar, que planeja novos padrões de desempenho, é atingida através do Ciclo PDCA ( $P$ para "Plan" ou Planejar). Portanto, o PDCA de melhorias modifica o $S D C A$, colocando este em um novo patamar de desempenho, o quê significa dizer que a conjugação desses compõem um processo de melhoramento contínuo (CAMPOS, 1992).

Observando o PDCA de um enfoque mais prático, FAESARELLA; SACOMANO \& CARPINETTI (1988:102), definem:

“... é um método de resolução de problemas onde as soluções são encontradas através de um processo estruturado e ordenado, em que cada passo depende da execução do anterior. Ele exige treinamento e educação..."

Face as características de resolução de problemas e controle das atividades, este método é utilizado pelas equipes de manutenção para a identificação, análise, solução e estabelecimento de procedimentos para a correção de um problema ou falha, bem como para a aplicação de planos de ação para melhorar o desempenho de equipamentos e sistemas. 
Assim, considerando-se o PDCA como um método de solução de problemas e proposição de ações para melhoria do desempenho, é recomenda sua aplicação por grupos multidisciplinares e multiespecialistas em oito fases:

1. Levantamento dos problemas e escolha do principal - através da técnica do Brainstorming.

2. Observação do problema com uma visão ampla e sob vários pontos de vista - levantando históricos, fazendo visitas ao local da ocorrência e analisando os dados levantados.

3. Busca da causa principal - também em um Brainstorming construir um diagrama de causa e efeito, utilizar a técnica da RCFA.

4. Estabelecimento de planos de ações para o bloqueio das causas raízes - treinando à equipe a utilizar a técnica do $5 \mathrm{~W} 1 \mathrm{H}$.

5. Ação - execução das ações planejadas.

6. Verificação após a execução - observar o local do problema após a execução da ação, anotando as mudanças. Nesta fase, se o problema ainda persistir, recomenda-se retornar à fase 2 para a análise das verdadeiras causas raízes.

7. Padronização dos procedimentos - estabelecer procedimentos simples para a solução e prevenção do problema, e criar dispositivos para evitar os descuidos.

8. Conclusão - recapitulação de todo o processo de solução do problema para trabalhos futuros, destacando os progressos alcançados e continuação da resolução dos demais problemas levantados na primeira fase, obedecendo as prioridades.

Deve-se ainda ressaltar a fundamental importância de características como: treinamento e a disciplina da equipe, essenciais para o sucesso da aplicação.

\subsubsection{Normas ISO (Série 9000)}

Segundo FAESARELLA; SACOMANO \& CARPINETTI (1988), a International Organization for Stadardization define o sistema de qualidade como a 
estrutura organizacional, procedimentos, processos e recursos necessários para a implementação da política, dos objetivos e das responsabilidades para o planejamento, o controle, a garantia e a melhoria de qualidade.

Com o objetivo de padronizar mundialmente a sistemática de qualidade, a $I S O$ iniciou, a partir de 1987, a criação das Normas Internacionais de Qualidade. Nesse contexto, a ISO 9000 é constituída de normas que apresentam um conjunto de recomendações para a implementação de sistemas de gestão e garantia da qualidade de produtos e serviços.

Focando a orientação para sua aplicação visando a garantia da qualidade do processo, têm-se as normas ISO 9001, 9002 e 9003, as quais são modelos de sistemas de garantia da qualidade que definem os requisitos dos procedimentos que devem ser utilizados para fins de garantia da qualidade externa, ou seja, a fim de demonstrar a capacidade de uma empresa em garantir a qualidade de seus processos em avaliações externas.

Face a aplicabilidade na manutenção, destaca-se a Norma ISO 9002, um modelo de sistema de qualidade que evidencia, para o cliente e fornecedor, a garantia da qualidade da fabricação e instalação. TAVARES (1996: 130) esclarece:

"A partir da revisão [das normas ISO série 9000], em 1994, a atividade-manutenção passou a ser considerada como um requisito de controle de processo (...) literalmente citada..."

Além disso, verifica-se que todas as seções desta norma (que no total apresenta 18 requisitos) são aplicáveis a manutenção. A ISO 9002 é considerada uma etapa do Programa de Qualidade na Manutenção por fornecer um guia completo para a realização dos serviços com a qualidade garantida, haja vista que a certificação de uma empresa implica que a manutenção esteja praticando os preceitos e procedimentos da Norma (PINTO \& XAVIER, 1998).

\subsection{Sistemas Informatizados de Apoio à Manutenção}

Cada vez mais as empresas buscam softwares adequados para auxiliar seus profissionais, processos administrativos e a fabricação. $\mathrm{Na}$ manutenção, se fazem indispensáveis devido a necessidades como: controlar custos, planejar 
serviços, garantir uma base de dados confiáveis, estabelecer uma cadeia de suprimentos, aplicar manutenções preventivas e preditivas, monitorar o processo e os equipamentos, promover um fluxo de informações eficiente, entre outras atividades.

"As exigencias atuais de confiabilidade e disponibilidade são de tal ordem que se impõe, aos gerentes de manutenção, responsabilidades que só podem ser executadas com ferramentas adequadas a gestão..." (TAVARES, 1999: 32).

Assim, cada vez mais nas instalações de processamento contínuo, devido a grande quantidade de instrumentos e equipamentos, softwares especializados se fazem indispensáveis para que haja um controle adequado das manutenções, bem como para possibilitar um gerenciamento de todos os ativos individualmente e do processo como um todo. Segundo NAGAO (1998), um sistema de gerenciamento de manutenção deve abranger alguns módulos de gestão de equipamentos, planejamento e programação, materiais e custos.

Outro aspecto importante no cenário atual é a necessidade da transparência e agilidade nas informações, o que torna indispensável o uso de softwares de fácil manuseio, para todos os níveis organizacionais da empresa, e integrados num sistema único dentro de uma organização, ou seja, estes devem conversar entre si e serem complementares. Atentos a isso, PINTO \& XAVIER (1999) comentam que ao se pesquisar no mercado um software para manutenção, deve-se levar em conta atualmente três fatores para o sistema: (1) ter interface para Windows, (2) estar apto para rodar em qualquer tipo de rede em uso, (3) o fornecedor deve garantir a integração com os outros sistemas em uso.

Quanto aos impactos dos sistemas informatizados na função manutenção, ANHESINE (1999) esclarece que esses softwares melhoram a eficiência da manutenção, mas em contrapartida não melhoram sua eficácia. Diante as modernas técnicas (métodos) focadas na qualidade e confiabilidade, como por exemplo o $5 S$, $T P M$ e $R C M$, um mix dessas junto as estratégias de manutenção é necessário para melhorar e otimizar o desempenho.

Três tipos de sistemas computacionais, que auxiliam na gestão da manutenção em processos de produção contínua, têm uma relação direta com este trabalho: (1) sistemas de gerenciamento, planejamento e controle; (2) sistemas especialistas de monitoramento contínuo e; (3) sistemas de informações. 


\section{Sistemas de gerenciamento, planejamento e controle}

Esses softwares que têm como principais funções: gerenciar as manutenções de rotina (corretivas e preventivas) e as inspeções (preditivas e detectivas); garantir um histórico e um banco de dados confiáveis dos equipamentos e instalações; apoiar à área de suprimentos e contratos com provedores de serviços, além de proporcionar a realização de grandes paradas planejadas com maior confiabilidade e eficiência. Normalmente são compostos por módulos de gestão de intervenções, gestão de custos, gestão de suprimentos, composição de históricos, aplicação das práticas de manutenção etc.

Um monitoramento contínuo nestes sistemas se faz indispensável para sua operacionalidade e confiabilidade. Também, são fundamentais treinamentos e reciclagens periódicas para todos os envolvidos.

\section{Sistemas especialistas de monitoramento contínuo}

São caracterizados pelos sistemas de supervisão de processo, on-line, onde é possível à edição de relatórios e gráficos para o acompanhamento da produção, consumos, performance de equipamentos, entre outros. Apesar de serem originalmente concebidos apenas para supervisão de processos, mostraram-se perfeitamente adaptáveis à aplicação das técnicas de manutenção preditiva em interface com os Sistemas Digitais de Controle Distribuído (SDCD).

À análise de milhares de variáveis em tempo real proporciona uma visão especializada do processo, de uma forma pontual e personalizada, promovendo a aplicação da engenharia de manutenção na sua essência. Além disso, esses softwares são fundamentais para uma estratégia de manutenção voltada a realização das intervenções em momentos de oportunidade, tornando as paradas planejadas um diferencial de mercado.

A eliminação das paradas imprevistas, uma significativa redução das perdas, a diminuição dos riscos potenciais de acidentes e agressão ao meio ambiente são alguns dos resultados que podem ser obtidos.

\section{Sistemas de informações}

São os sistemas informatizados de informações utilizados para garantir 
fatores importantes, como: o fluxo de dados necessários entre as áreas da organização, a troca de informações entre os funcionários, as comunicações e procedimentos burocráticos, e as relações com o ambiente externo à empresa. Como principais exemplos têm-se a Internet e a Intranet.

Para a manutenção, um fluxo de informações eficiente e confiável é fundamental na promoção das interfaces necessárias entre as várias áreas e as equipes de manutenção das áreas produtivas, a fim de garantir a sinergia durante as intervenções nos processos, bem como a troca de informações e experiências, com a realização de benchmarking (interno e externo).

Além disso, os sistemas de informações têm um importante papel para o auto-aperfeiçoamento técnico-cultural das pessoas, o que contribui para o desenvolvimento da equipe no ambiente de mercado atual.

\subsection{Os Recursos Humanos e a Cultura da Organização}

As pessoas tornaram-se o principal diferencial das organizações no mercado globalizado. A capacidade destas em adquirir continuamente conhecimento e transformá-lo em habilidades, agir com autonomia e responsabilidade, dentro de um padrão de disciplina, define sua contribuição para a organização, empregabilidade e potencial em agregar mais valor ao negócio.

As empresas da atualidade buscam criar um ambiente que promova e catalise essas características nos seus profissionais, com uma visão voltada ao aprendizado contínuo, trabalho em equipe, valorização das pessoas, lideranças fortes, e ao bem estar do clima da organização, sempre fundamentado em uma forte "cultura de mudanças".

Na função manutenção, o conhecimento e as atitudes das pessoas têm um papel fundamental. Valores como comprometimento, organização, padronização, disciplina e companheirismo são indispensáveis a uma equipe que deseje atuar de forma estratégica dentro do processo produtivo.

Neste contexto, alguns aspectos podem ser destacados quanto a gestão dos profissionais da manutenção na atualidade: (1) treinamento e desenvolvimento; 
(2) gerenciamento e liderança; e (3) a cultura e o clima organizacional.

\section{Treinamento e desenvolvimento}

Para CAMPOS (1995), gerenciar o crescimento do ser humano significa para as empresas "dominar o mercado". O desenvolvimento das pessoas tem de ser conduzido de forma planejada e constante, visando:

- atualização de conhecimentos;

- promoção da motivação;

- desenvolvimento de habilidades;

- modificação da maneira de pensar.

Enfocando a manutenção nas indústrias de processo contínuo, NAGAO (1998: 82) comenta:

"Devemos estar sempre investindo na educação e formação de nossos funcionários, e ter um sistema estruturado de formação, com análise do perfil do cargo e do indivíduo, suprindo as suas necessidades e buscar o seu desenvolvimento profissional."

O treinamento em grupo, a prática, o mútuo e o auto-desenvolvimento são as principais ferramentas encontradas na busca por esses fatores. A filosofia da QT tem dado suporte à valorização necessária do aspecto humano nas organizações, através da implementação de técnicas como Kaizen e TPM.

\section{Gerenciamento e liderança}

Num ambiente em constante mudança, onde das pessoas dependem os resultados, o domínio na aplicação e a clareza na percepção da contribuição dos fatores gerenciamento e liderança são fundamentais. KOTTER (1997), estabelece uma relação entre eles e os caracteriza dentro da estratégia de gestão das empresas:

- Gerenciamento - é um conjunto de processos que podem manter um complicado sistema de pessoas e tecnologias funcionando satisfatoriamente.

- Liderança - é um conjunto de processos que cria a organização em primeiro lugar, ou as adapta para modificar significativamente as circunstâncias. 
Assim, gerenciar está ligado a previsibilidade e ordem, ou seja, ao controle e manipulação de "dados", enquanto liderar define como deverá ser o futuro, alinhando o pessoal e dando inspiração para a ação gerando a mudança, a partir das "pessoas".

Numa pesquisa em cerca de 300 empresas do mundo, o mesmo autor observou que nos processos de transformação já comuns no dia-a-dia das organizações, uma mudança "bem sucedida" consiste em 70 a 90\% de liderança e 10 a $30 \%$ de gerência.

Ainda sobre o aspecto liderança, KOTTER (1997: 30) escreve:

"Para a maioria das organizações, o maior desafio é liderar a mudança. Somente a liderança pode destruir muitas fontes de inércia, (...) pode motivar as ações necessárias para alterar o comportamento de modo significativo, (...) pode fazer a mudança acontecer, fixando suas raízes na verdadeira cultura de uma organização."

Para os atuais gerentes e profissionais de manutenção, desenvolver a habilidade da liderança é a garantia de sua empregabilidade, importância para a organização e sucesso no desempenho de sua equipe. HAMMER \& CHAMPY (1994), esclarecem que os executivos precisam ser líderes capazes de influenciar e reforçar os valores e as crenças dos empregados através de suas palavras e ações.

\section{A cultura e o clima organizacional}

Como características de destaque na cultura das organizações do século XXI, KOTTER (1997) relaciona:

- ser externamente orientada;

- investir em empowerment dos funcionários;

- ter rapidez na tomada de decisões;

- ser transparente e franca;

- tolerar riscos.

Nota-se que, para o atendimento desses aspectos, o local de trabalho deve estar centrado nas pessoas, ou seja, a cultura e o clima organizacional têm que ser propícios ao desenvolvimento das habilidades dos profissionais e a constante elevação do moral. 
Segundo CAMPOS (1995), as habilidades são elevadas através da educação e treinamentos contínuos, enquanto o moral é o resultado de um local de trabalho onde as pessoas tenham liberdade de ser espontâneas e ter iniciativas.

NAGAO (1998: 83), coloca a cultura organizacional como base da excelência em manutenção industrial:

"A empresa deve desenvolver uma cultura organizacional fundamentada em princípios e valores que norteiam as atitudes $e$ os rumos da organização. Um clima organizacional valorizando o espirito de equipe, o espirito empreendedor, a criatividade e o indivíduo, são fundamentais em empresas que buscam a excelência. É necessário construir uma empresa que tenha capacidade de aprender e evoluir."

É lógico dizer que a influência da cultura e do clima da organização sobre as equipes de manutenção é total, sendo indispensável o desenvolvimento contínuo e conjunto destas face a empresa como um todo.

\subsubsection{O homem de manutenção}

O sucesso da atuação da manutenção está estreitamente relacionado ao homem, o que torna fundamental que este tenha características básicas à um profissional voltado para o futuro, como por exemplo: visão global, polivalência, multiespecialização e versatilidade, essenciais dentro de um ambiente em mudança.

Neste contexto, PINTO \& XAVIER (1998) colocam que o homem de manutenção tem reagido rápido à estas mudanças, através de uma crescente conscientização de quanto uma falha de equipamento afeta a segurança e o meio ambiente. Também, nota-se uma maior atenção para a relação entre manutenção e qualidade do produto, e a busca incessante por alta disponibilidade operacional aliada a redução de custos.

É muito discutida a importância das pessoas no contexto da manutenção, discutindo sua evolução, novos desafios, o perfil atualmente desejado, entre outras questões. Atualmente, as empresas estão investindo maciçamente no seu capital intelectual, e um dos principais focos tem sido o homem de manutenção, devido a amplitude que tomou a função manutenção. 
Neste sentido, ANHESINE (1999) relaciona de forma sintética alguns pontos que devem ser explorados pelas organizações para o desenvolvimento dos seus profissionais de manutenção:

- Auto-imagem - estruturação de forma positiva.

- Auto-consciência - perceber-se a si mesmo como pessoa e profissional.

- Autoconfiança - garantir aspectos decisórios.

- Automotivação - força que supera as circunstâncias adversas.

- Autodeterminação - vontade e persistência em prol dos objetivos traçados.

- Autonomia - livre arbítrio para tomar decisões, errar, corrigir e aperfeiçoar.

Além disso, podemos citar outras características diretas para o sucesso desse profissional, como: liderança, trabalho em grupo, criatividade, flexibilidade a mudanças, e uma maior assertividade ao dizer o que pensa e o que é preciso fazer, mesmo quando tornar-se necessário enfrentar pessoas de posição hierárquica mais elevada (KRÖNER, 1999).

Outro aspecto bastante discutido é a capacidade de gestão do homem de manutenção, relacionada muitas vezes a enorme quantidade de técnicas, ferramentas e programas voltados a qualidade colocados a sua disposição. Saber aplicar estas técnicas, gerenciar as pessoas, mostrar resultados, manter sua equipe atualizada e atuante para com a produção e a organização são algumas das funções esperadas de um gestor de manutenção.

Visando definir como seria o gerente de manutenção do futuro, KRÖNER (1999: 81) escreve:

"O gerente de Manutenção tradicional está deixando de existir. Novas estruturas de trabalho, reorganizações e transferências de atividades, participação de Terceiros, novos perfis profissionais, fazem com que novas hierarquias e estruturas organizacionais mudem as exigências profissionais dentro de perfis profissionais cada vez mais amplos. Com a manutenção incorporada ‘a operação, não existirá mais um responsável único pela manutenção."

Também, para cumprir seu papel com excelência, o gerente de 
manutenção deve ser, antes de tudo, um líder: influenciando as pessoas, sendo um agente de mudanças, propagando a motivação, promovendo a busca pelo aperfeiçoamento contínuo, aplicando as melhores práticas e o benchmarking.

NAGAO (1998:82), comenta: "O domínio das técnicas é parte integrante do moderno Gerenciamento da Manutenção. Podemos ter as melhores ferramentas e sistemas de manutenção, porém nada funciona sem o perfeito domínio do uso adequado destas técnicas pelo homem. O homem é o elemento chave do sucesso da Manutenção."

Contudo, a estreita relação entre a gestão e as ferramentas da manutenção com os programas e técnicas da qualidade visam promover a sinergia necessária entre as equipes de operação e manutenção da planta fabril, onde a figura do homem de manutenção surge como um ponto fundamental, pois é este que será o gestor de todas essas técnicas, ferramentas e programas de forma integrada, ou seja, com a finalidade de uní-las para a realização da atividade fim de uma organização com sucesso e superação.

\subsection{A Gestão da Manutenção}

Todas as práticas, técnicas, métodos e filosofias já descritas são utilizadas para uma gestão da manutenção voltada à qualidade, conhecimento e produtividade, ou seja, à excelência. $\mathrm{O}$ suporte dos sistemas informatizados e a valorização das pessoas tornaram-se diferenciais indispensáveis.

Assim, essas inúmeras ferramentas de gestão, quando usadas corretamente junto as práticas e técnicas de manutenção podem levar a excelentes resultados e proporcionar a implementação de um modelo de gestão da manutenção adequado as necessidades do processo produtivo.

O contínuo investimento no treinamento e desenvolvimento dos profissionais, o fortalecimento das lideranças, a gestão do clima da organização e a promoção de uma cultura de mudanças são aspectos ideais para a aplicação de uma política de manutenção efetiva, que tem como principal objetivo tornar a manutenção uma função estratégica. 
Os homens de manutenção devem estar preparados para atuar de forma conjunta com as equipes de operação. As metas gerenciais e a estabilidade do processo devem ser ideais comuns a todas as áreas produtivas e funções, fazendo com que a equipe de manutenção ocupe um espaço determinante na gestão da produção.

Nas indústrias do setor papeleiro, os principais produtos da manutenção são a disponibilidade e a confiabilidade, concretizados através de uma atuação estratégica nos equipamentos e instalações, em virtude das características do processo e das necessidades de mercado.

$\mathrm{O}$ alinhamento entre as pessoas, funções, especialidades e áreas produtivas, administrativas e de apoio, além de uma rede eficaz de informações são alguns dos fatores fundamentais para o bom desempenho do processo produtivo.

Na última década, uma avalanche de novos conceitos e mudanças foram incorporadas às organizações tornando-se necessária uma orientação comum, sendo isto motivo de reflexão constante dos gestores na atualidade. Neste sentido, MOUBRAY (2000) coloca que os gerentes de manutenção buscam um esquema estratégico que sintetize os novos avanços de uma forma coerente, de modo que eles possam avaliá-los racionalmente e aplicar aqueles de maior valor para suas empresas.

A união das funções manutenção e qualidade, aliadas as fortes lideranças e aos sistemas informatizados constituem um modelo de gestão voltado a produtividade e a uma cultura de mudanças. A gestão da manutenção dá-se em função do processo e da máxima produtividade, num ambiente de trabalho sadio, prazeroso e voltado às contínuas mudanças, onde o treinamento e desenvolvimento das pessoas é a base da política de valorização do conhecimento e das competências, com ilustrado na figura 3.2.

$\mathrm{Na}$ orientação das equipes de manutenção, junto as de operação e áreas de apoio dentro do processo produtivo, quatro aspectos se destacam:

A. Política de Manutenção - confiabilidade e disponibilidade do processo, e estratégia de intervenções na planta.

B. Gestão da Qualidade - padronização das atividades, otimização dos processos, redução e eliminação das perdas. 


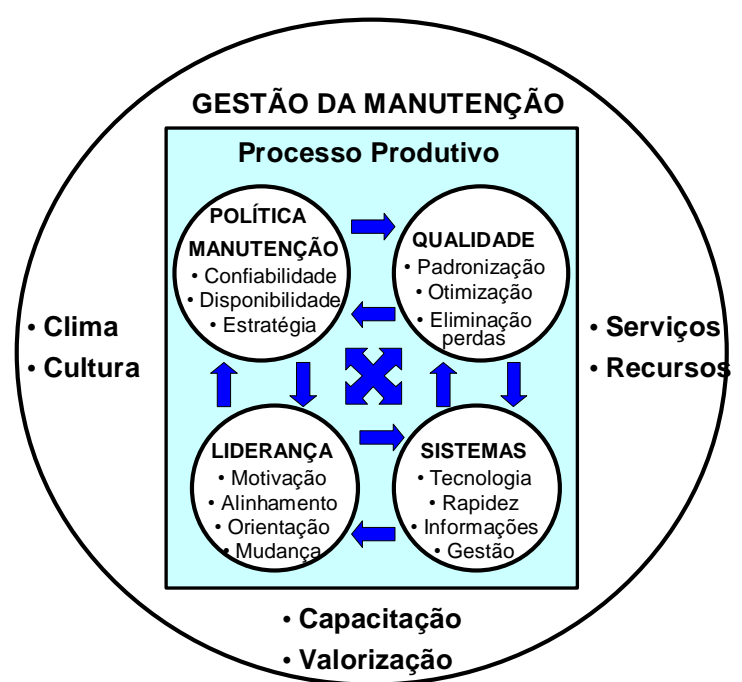

Figura 3.2 - Gestão da manutenção voltada ao processo produtivo.

C. Liderança - motivação, inspiração, alinhamento, orientação, quebra de paradigmas e promoção de mudanças.

D. Sistemas Informatizados - novas tecnologias, rapidez, versatilidade, rede de informações e gestão direcionada.

O gerenciamento desses aspectos e da sinergia entre eles, voltados à gestão do conhecimento e à prática do benchmarking favorecem uma atuação da manutenção de forma estratégica.

\subsubsection{A gestão compartilhada do processo produtivo}

A integração entre as equipes de operação e de manutenção é indispensável na busca pela confiabilidade, produtividade e qualidade.

Nos processos de produção contínua, onde as paradas planejadas são estratégicas, um trabalho em conjunto é essencial para o atendimento e superação das metas estabelecidas. Da mesma forma, para o monitoramento contínuo do processo, a manutenção sob condição e a prática da engenharia de manutenção, a ampla e efetiva participação dos profissionais de operação é determinante. 
Como a atividade fim de todos os envolvidos na produção é produzir, as metas, desafios e diretrizes devem ser compartilhadas, bem como a responsabilidade pelo processo e planta, de acordo com a figura 3.3.

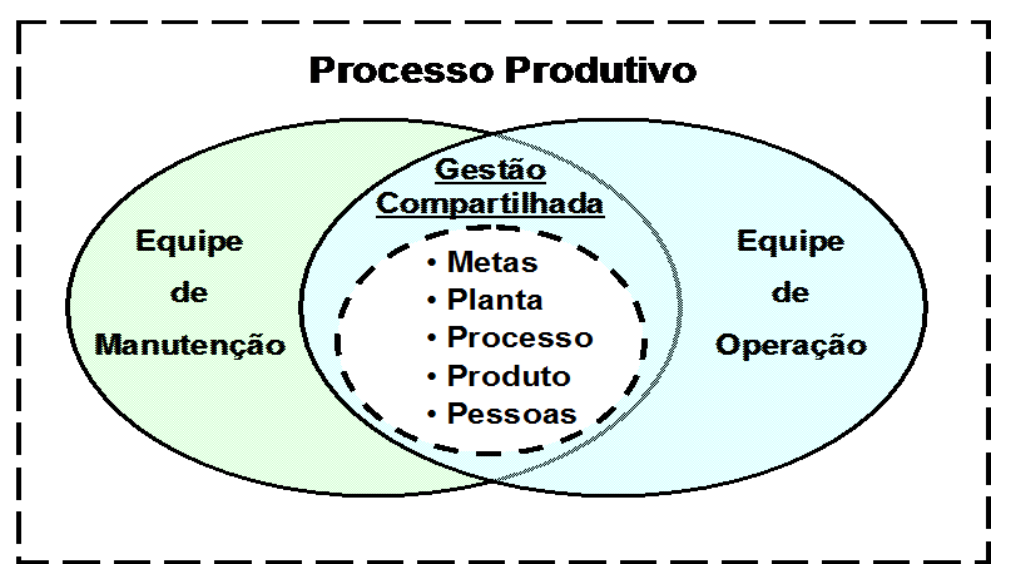

Figura 3.3 - Gestão compartilhada do processo produtivo.

Na busca por esse trabalho em conjunto, PINTO \& XAVIER (1999) destacam duas maneiras:

- Educação - através de uma trabalho persistente em treinamento, vivências, visitas de alta competitividade, depoimentos de pessoas reconhecidas como tendo experiências bem-sucedidas, enfim, é uma questão de sobrevivência e estratégica.

- Organização - é preciso criar mecanismos organizacionais que favoreçam a formação destas equipes mistas de manutenção e operação, trabalhando integradas para a otimização do todo. Isto pode ser conseguido através de uma estrutura matricial, times multifuncionais envolvendo operação, manutenção, engenharia, segurança, entre outras especialidades.

A visão global e sistêmica é fundamental para a funcionalidade da gestão compartilhada da produção, que tem caráter comportamental e promove o contínuo aprendizado dos profissionais diretamente ligados ao processo de fabricação.

\subsubsection{A estratégia de intervenções na planta fabril}

É hipótese deste trabalho, que a atuação estratégica da equipe de 
manutenção é resultado do estabelecimento de uma forte política de manutenção, baseada em práticas bem definidas, ferramentas e técnicas de suporte específicas e voltadas a qualidade, bem como alicerçada em uma forma de gestão compartilhada da produção que privilegia a visão sistêmica do negócio.

Assim, as equipes de manutenção das indústrias de processo de produção contínua precisam deixar de ser apenas eficientes para se tornarem eficazes, pois já não basta a realização de reparos tão rápido quanto possível, mas sim é preciso manter a função do equipamento disponível para a operação, bem como evitar falhas e reduzir os riscos de uma parada de produção imprevista.

\section{"A manutenção deve ser organizada de tal maneira que o equipamento pare de produzir somente de forma planejada: é a manutenção planejada." (PINTO \& XAVIER, 1999: 12).}

Nesse contexto, a partir do monitoramento contínuo da planta, da prática da EM e da aplicação de técnicas e ferramentas específicas em conjunto com a equipe operacional, têm-se uma estratégia de intervenções como abaixo:

- Intervenções em Momentos de Oportunidade (MO), apontados pela equipe operacional ou pelo processo;

- Paradas Setoriais, realizadas periodicamente em equipamentos ou sistemas específicos;

- Paradas Gerais, previamente estabelecidas por estratégia de mercado e necessidades técnicas dos equipamentos e sistemas, as quais são realizadas anualmente no setor papeleiro.

Garantir a máxima disponibilidade e capacidade de produção, intervindo no processo somente em momentos apontados pela equipe operacional diante uma necessidade inerente à operação da planta, ou seja, que não denote uma intervenção somente para reparos de manutenção, são as principais metas dessa estratégia de manutenção. Para isso, a realização de paradas planejadas com segurança, eficiência e estratégia é vital. 


\section{CAPÍTULO 04}

\section{O GERENCIAMENTO E CONTROLE DE PARADAS PLANEJADAS}

\subsection{Introdução}

A busca por métodos e procedimentos para o estabelecimento e padronização do planejamento, controle, execução e avaliação dos eventos de parada planejada têm sido uma constante nas empresas do setor papeleiro, já que formas para seu gerenciamento adequado não estão bem definidas na literatura, até hoje.

Poucos são os trabalhos que discutem especificamente esse assunto, mais raras ainda são abordagens que comentam sobre o ambiente necessário que proporcione a aplicação de uma sistemática de forma efetiva, fazendo com que os profissionais das empresas do setor atuem normalmente por instinto e experiência.

Visando a identificação das ações comuns no planejamento e desenvolvimento desses eventos e de ferramentas que possibilitem sua sistematização, bem como a discussão de aspectos fundamentais para otimizações, com a utilização dos pontos fortes de cada enfoque e a composição de um método de gerenciamento adequado para os processos de produção de celulose e papel, objetivo principal deste trabalho, algumas abordagens disponíveis serão comentadas.

Além disso, para a verificação das principais dificuldades encontradas na prática empresarial, serão apresentados todos os detalhes do planejamento e execução de uma Parada Geral (PG) numa planta de produção de celulose e papel.

\subsection{Algumas Abordagens}

Com a caracterização da manutenção e da qualidade como funções estratégicas nas organizações da atualidade, alguns trabalhos voltados ao 
gerenciamento de paradas têm sido desenvolvidos a partir de experiências históricas das empresas, benchmarking das melhores práticas e análise desses eventos por consultorias e auditorias externas. É importante esclarecer que esses trabalhos são voltados aos processos de produção contínua, tanto sob o enfoque teórico como prático, porém não estão necessariamente vinculados às indústrias papeleiras.

\subsubsection{Controle dinâmico de grandes reparos - TAVARES}

Em uma abordagem literária, TAVARES (1999) trata do planejamento e controle de paradas planejadas como "controle dinâmico de grandes reparos".

Na sua visão, esta atividade está entre as oito que devem compor o sistema de gestão da manutenção de uma planta industrial, e para seu gerenciamento são necessárias ações específicas voltadas diretamente ao processo, equipamentos e sistemas envolvidos.

O autor não estabelece um método a ser seguido, porém comenta alguns aspectos fundamentais que devem ser observados nesses momentos:

- a realização de reuniões com os supervisores de operação e manutenção - objetivando a redução das indisponibilidades, nivelamento dos recursos de apoio necessários e análise dos acidentes e riscos potências;

- a necessidade de sistemas informatizados de apoio - devido à complexidade da rede de tarefas e recursos envolvidos, quantidade de dados a serem processados, e a possibilidade de ocorrências aleatórias durante os trabalhos;

- a observação dos históricos - a fim de possibilitar avaliações prévias quanto aos recursos e tempos para as intervenções;

- estabelecimento dos cronogramas, interfaces e caminhos críticos com a finalidade de permitir verificações e acompanhamentos periódicos, e rápidas análises quando da inclusão de novas atividades e/ou atrasos que alterem os tempos estimados, atualizando as previsões; e 
- a formulação de planos e programas para as atividades e recursos de apoio (novos equipamentos, ferramentas, andaimes, transportes, lubrificações etc.) - visando evitar atrasos durante execução.

Ainda, buscando caracterizar um método de controle eficiente, esclarece:

"A implementação do Controle Dinâmico de Grandes Reparos necessitará de um ou mais elementos para acompanhamento e controle. Estes elementos, que devem ter embasamento técnico tanto das tarefas a serem executadas quanto nos mecanismos de controle, deverão dar cobertura a todo o reparo (...) a fim de coletar e analisar todos os dados das atividades, transferir esses dados para o processamento, obter e distribuir relatórios e, se necessário efetuar registros quanto as deficiências apresentadas pelo programa." (TAVARES, 1999:128).

Um enfoque técnico e específico marca a visão deste autor, onde aspectos como a sinergia entre as equipes de manutenção e operação, a necessidade de sistemas informatizados e as mobilizações para o acompanhamento e verificações durante o evento mostram sua preocupação quanto a fatores essenciais na realização de paradas planejadas.

\subsubsection{Planejamento e controle de paradas de manutenção - VIANNA}

Dentro de um enfoque gerencial, VIANNA (1998) explica que nas grandes instalações industriais, as paradas planejadas caracterizam-se na "atividade de manutenção preventiva mais importante do ciclo de operação dos equipamentos". Os históricos da planta e os planos de produção das companhias normalmente determinam a época em que esses eventos devem ocorrer.

Face à importância do sucesso no planejamento e controle das atividades a serem realizadas, o autor destaca algumas necessidades básicas:

- uma organização adequada para a gerência de todas as atividades;

- uma sistemática eficaz de planejamento e controle;

- um sistema adequado de informações técnicas;

- um sistema de processamento de dados para o planejamento inicial e atualizações durante o evento. 
Com isso, visando definir uma seqüência para o gerenciamento estruturado desses eventos, são utilizadas duas etapas: a etapa de planejamento, que tem como objetivos principais identificar as necessidades e coordenar as providências para obtenção dos recursos; e a etapa de controle, que visa o estabelecimento de um sistema de verificação da evolução das tarefas, permitindo um acompanhamento contínuo, revisão e atualização das programações e previsões. Abaixo, têm-se essas duas etapas em detalhes:

1. Planejamento da parada:

(a) Estabelecer um cronograma anual de paradas;

(b) Constituir um grupo de paradas - multifuncional e multiespecia-lista, com coordenação geral;

(c) Analisar, detalhar e preparar os serviços com antecedência;

(d) Alimentar e programar as Ordens de Serviços (OS's);

(e) Determinar os caminhos críticos e a duração da parada do processo;

(f) Nivelar os recursos - com auxílio de programas computacionais;

(g) Contratar pessoal externo;

(h) Fazer os preparativos finais - emissão das permissões para trabalhos nas áreas, checagem das ferramentas especiais, equipamentos de segurança etc.;

(i) Emissão dos pedidos de compra.

2. Controle da parada:

(j) Acompanhar os serviços - atualização das tarefas envolvidas, dos recursos utilizados e disponíveis, programação e apropriação de novas atividades, e informações sobre desvios no plano global;

(1) Emitir as OS's para novas atividades;

(m) Revisar e atualizar os programas - quando da ocorrência de grandes desvios e/ou acréscimos substanciais nos trabalhos;

(n) Fazer o nivelamento de recursos para trabalhos adicionais, bem como a cada $15 \%$ do tempo global previsto para a parada.

Com isso, torna-se necessário notar o maior enfoque aos aspectos de nivelamento de recursos e programações das atividades. Os métodos Program Evaluation and Review Technique (PERT) e Critical Path Method (CPM) são 
detalhados pelo autor, dando bases teóricas para a promoção de uma maior assertividade e otimização no planejamento dos tempos e recursos envolvidos.

A busca por uma organização adequada e centralizada para a gerência de todas as atividades e o estabelecimento de um método eficaz de planejamento e controle demonstram o caráter gerencial e estatístico implementado, com a divisão do evento em duas etapas e a definição de uma seqüência de atividades para a padronização das ações.

Entretanto, as paradas planejadas são caracterizadas pelo autor essencialmente como uma ação de manutenção preventiva, idéia que no presente trabalho não se aplica, pois nem sempre uma atividade de manutenção é a mais demorada, ou seja, o caminho crítico do evento, e a necessidade da parada de produção é vislumbrada para limpezas e inspeções operacionais, que definem sua duração mínima.

\subsubsection{Planejamento e controle de paradas - VERRY}

Nesta abordagem, voltada às refinarias de petróleo, nota-se uma maior ênfase a fatores como o comportamento humano, a disciplina na tratativa de cada atividade de planejamento e controle, e a experiência prática. Na visão de VERRY (2000), o homem é a chave para o sucesso das paradas planejadas e, por isso, deve ser continuamente trabalhado.

Além disso, realizar um excelente planejamento e dispor das ferramentas adequadas para segui-lo é fundamental. Baseado em aplicações práticas e dados históricos, descreve em quatro etapas os principais pontos a serem trabalhados:

1. Aspectos comportamentais:

(a) Comprometimento da equipe executante - estabelecer o trabalho em equipes, difundir as metas desejadas e a estratégia;

(b) Comportamento das contratadas - buscar sua cumplicidade;

(c) Dinâmica de grupo - trabalhar o comportamento;

(d) Comunicação - prover informativos gerais;

(e) Definição de atribuições - com clareza e de forma oficial;

(f) Comprometimento da alta gerência - em todo o processo. 
2. Planejamento:

(g) Check-list do planejamento - momento em que todos os pontos são revistos com antecedência;

(h) A aplicação dos Métodos $P E R T / C P M$ - definição da lista de atividades indispensáveis, quadros de dependência e diagramação;

(i) Programação das atividades - identificação dos caminhos críticos, nivelamento de recursos, preparação de cronogramas específicos para cada atividade e recurso de apoio, e das curvas de avanço (para o acompanhamento dos trabalhos);

(j) Emissão da lista de serviços com antecedência - resultantes das necessidades da Operação, Manutenção, Inspeção e Engenharia;

(k) Definição das atribuições - distribuição dos serviços com responsabilidades totais, ou seja, desde a observação de seu pedido até a execução e entrega;

(1) Contratação de serviços externos - utilização de bônus por adiantamento de prazo da parada, e o estabelecimento de mecanismos para medir os fatores segurança e qualidade;

(m) Utilização de Softwares de apoio - cronogramas PERT, definição do(s) caminho(s) critico(s), nivelamento de recursos e estabelecimento dos prazos;

(n) Análise de impacto ambiental - ações preventivas e contingentes;

(o) Análise de risco para a segurança - bloqueando as causas básicas;

(p) Análise de risco de atraso - reuniões periódicas e planos de ações;

(q) Elaboração dos cronogramas de entrega de sistemas - datas de liberação;

(r) Organização pré-parada com dois organogramas diferentes: um para providências de pré-parada, outro para o apoio à paralisação.

3. Coordenação e controle da parada:

(s) Controle de horas extras - limitação da quantidade por serviço, dando prioridade ao(s) caminho(s) crítico(s);

(t) Logística - promoção da disposição adequada dos recursos e atividades de apoio, a realização da "Integração" aos envolvidos;

(u) Reuniões de acompanhamento - gerenciais direcionadas (visão global do status do evento), técnicas por frente de serviço, e as de partida; 
(v) Amostragem de trabalho - análises específicas das contratadas por profissional, através do acompanhamento em campo;

(w) Segurança - estabelecimento de penalizações e diretrizes, realização de reuniões (principalmente com provedores de serviços) e definição de responsáveis;

(x) Apoio à partida - formação de uma equipe específica para a partida, coordenada por um profissional de instrumentação.

4. Avaliação da parada:

(y) Buscando a melhoria contínua, sugere-se a formação de grupos e perguntas O que deu certo? O que deu errado?

(z) Formação de grupos multidisciplinares para a análise de cada problema Árvores de Causas e definição de planos de ação para evitar reincidências.

Como principais resultados da adoção dessas práticas estabelecidas, o autor destaca a realização de paradas planejadas no "prazo" e com "segurança".

De forma geral, a quantidade de exemplos descritos e a preocupação com a transferência de tecnologia e com o benchmarking, sempre com a demonstração do “como fazer", garantem a legitimidade e aplicabilidade do método proposto.

Guardadas as devidas particularidades inerentes ao ambiente de aplicação e as características de mercado, face ao enfoque do presente trabalho, esta abordagem se mostra bastante abrangente e atual.

\subsubsection{Shutdowm and outage management - DRESSER \& CANIPE}

Face a um estudo voltado as indústrias papeleiras, DRESSER \& CANIPE (2000) discutem as "Outages" (Paradas Gerais da planta, onde o processamento é totalmente cessado), e as "Shutdowns" (Paradas Setoriais de alguns equipamentos ou sistemas para manutenções preventivas, limpezas e inspeções), com o enfoque na Confiabilidade $(R)$, Qualidade $(Q)$ e Produtividade $(S)$.

Para eles, essas Paradas são os "ingredientes chaves" para o sucesso das indústrias no setor. Na Administração da Produção com Confiabilidade (Reliable 
Production Management - RPM), método de gestão descrito e utilizado no ambiente desta abordagem, a liderança e a administração das paradas planejadas caracterizam uma de suas quatro áreas de ação, sendo que a relação estabelecida entre os fatores $R$, $Q$ e $S$ compõem a Eficiência Total da Produção (Overall Production Efficiency $O P E$ ), conforme a equação: $O P E=\mathrm{R} \% * \mathrm{Q} \% * \mathrm{~S} \%$.

Nesse contexto, o principal objetivo observado é o estabelecimento de uma forma de administração efetiva para as PG, bem como sua otimização constante enfocando a $O P E$. Para as PS, os mesmos princípios podem ser utilizados.

Dessa forma, os autores descrevem cinco etapas chaves, chamadas de “ciclos", para o gerenciamento desses eventos:

1. Ciclo de decisão - pré-planejamento macro, com a definição da estratégia, regras, responsabilidades, formação de grupos, estabelecimento do(s) caminho(s) crítico(s) e da indisponibilidade total da planta;

2. Ciclo de planejamento e programação - análise e detalhamento de todos os trabalhos e atividades, e a emissão do Cronograma Master. Recomenda-se que esta etapa esteja concluída cerca de três meses antes do início do evento e, tratando-se de paradas setoriais, os cuidados devem ser redobrados;

3. Ciclo de execução - após a completa parada dos equipamentos e sistemas tem-se o início dessa etapa. Nela dá-se o acompanhamento da performance dos trabalhos, as reuniões periódicas com a gerência e a observação e análise das oportunidades;

4. Ciclo de partida da planta - é tido como o momento definitivo para o sucesso do evento, e compreende: procedimentos de comissionamento operacionais, checklists para equipamentos e sistemas, planos de contingências para imprevistos e um fluxo de informações eficiente;

5. Ciclo de estabilização do processo - contempla a primeira semana de operação do processo produtivo após a parada, período que requer cuidados especiais e específicos até a normalização da produção. As análises minuciosas dos parâmetros do processo, qualidade do produto e a realização de reuniões em grupos para o levantamento dos pontos bons e ruins observados são as principais atividades nesta etapa. 
Ainda, ao final da quinta etapa é dado o início ao pré-planejamento da parada seguinte, com a elaboração de uma lista preliminar de serviços, e a definição de planos de ações para os pontos falhos observados. Todas as informações reunidas são encaminhadas a equipe do ciclo de decisão, que inicia os trabalhos para o planejamento do próximo evento.

A especial atenção aos momentos e procedimentos de parada e partida da do processo destacam-se neste método, o que sem dúvida é uma preocupação comum nas indústrias do setor papeleiro quando da realização de paradas. Paralelamente, a sinergia entre as equipes de operação e manutenção é colocada como essencial e indispensável.

A busca pelo aperfeiçoamento contínuo do gerenciamento, planejamento e controle das paradas planejadas, vistas sob o ponto de vista dinâmico e constante, são aspectos importantes que se destacam nesta abordagem.

\subsubsection{Sistema de gestão de paradas programadas - ABS SERVIÇOS}

Num trabalho realizado in-loco na VCP_LA, a ABS Serviços desenvolveu um projeto cujos objetivos caracterizavam um "incremento na gestão da produtividade" através da otimização na utilização dos recursos, aperfeiçoamento dos procedimentos de execução das tarefas, uniformização da gestão de manutenção e reciclagem de conceitos comportamentais e gerenciais.

Visando sempre a disponibilidade e a confiabilidade dos equipamentos, fatores fundamentais para o atendimento às arrojadas metas de produção no setor, as principais áreas diagnosticadas e trabalhadas foram a manutenção e a operação, e devido às necessidades identificadas em cada Célula Produtiva $(\mathrm{CP})$ foi desenvolvido o Sistema de Gestão de Paradas Programadas PCIC (Planejar - Controlar - Informar - Cobrar), um método aplicado em cada CP face a suas particularidades, onde são consideradas quatro fases básicas para seu gerenciamento:

1. Planejamento:

(a) Identificação dos trabalhos, procedimentos, tempos, recursos, local físico e objetivos do evento; 
(b) Elaboração de cronogramas específicos para atividades críticas;

(c) Participação indispensável das áreas de apoio nas reuniões de planejamento segurança, almoxarifado, contratadas etc.;

(d) Elaboração de um plano de contingências para realização de inspeções e lubrificações de oportunidade;

(e) Elaboração de relatórios gerenciais com o plano de parada.

2. Controle da execução:

(f) Estabelecimento de check's periódicos - comparativos previsto versus real;

(g)Definição de um coordenador de parada - devido à interação das diversas especialidades e áreas;

(h) Monitoramento das atividades extras identificadas;

(i) Acompanhamento dos custos e desvios.

3. Informação:

(j) Alimentação do sistema de informação - registro das ordens de trabalho e interferências, atualização dos cronogramas, etc.;

(k) Análise comparativa entre o planejado e o real;

(1) Elaboração de relatórios gerenciais com dados reais apontados.

4. Cobrança:

(m) Verificação e análise dos desvios;

(n) Levantamento dos pontos fortes e fracos identificados;

(o) Reuniões em grupos para a avaliação dos ajustes necessários para evitar reincidências na próxima parada do processo.

A elaboração de relatórios de acompanhamento, proporcionando um fácil controle e uma visão sintética e estatística do evento são ferramentas funcionais que se destacam nesta abordagem. O enfoque é para o controle das intervenções com a busca pelo aperfeiçoamento e máxima eficiência da mão-de-obra de manutenção, apropriada para paradas programadas de curta duração. 


\subsection{Análise Comparativa}

A diversidade e abrangência observadas nos enfoques apresentados requerem destaques, pois foram reunidas visões de origem acadêmica, prática e especialista. Sinteticamente, observam-se como principais pontos de atenção:

- TAVARES - sem método definido, ações específicas às intervenções na planta fabril, destaque-se à sinergia entre as equipes de operação e manutenção.

- VIANNA - método dividido em duas etapas, visão gerencial e estatística, utilização dos métodos $P E R T-C P M$, relaciona as paradas planejadas com a manutenção preventiva.

- VERRY - método em quatro etapas, ênfase ao comportamento humano e à disciplina na aplicação de técnicas, visão prática, prazo e segurança como fatores estratégicos e a utilização de ferramentas específicas.

- DRESSER \& CANIPE - método dividido em cinco etapas (ciclos), dinâmico e constante (formando um "ciclo fechado"), enfoque à confiabilidade, qualidade e produtividade, destaque-se a sinergia entre as equipes de operação e manutenção.

- ABS SERVIÇOS - método em quatro etapas, Sistema PCIC (Planejar-Controlar-Informar-Cobrar), ênfase ao comportamento humano, utilização de ferramentas específicas, destaque a sinergia entre as equipes de operação e manutenção.

É importante observar que todos esses trabalhos versam sobre as paradas planejadas em processos de produção contínua, porém com objetivos e ambientes diferentes. Mesmo assim, podem-se relacionar as principais características comuns:

- a divisão do gerenciamento das paradas planejadas em etapas, normalmente três: planejamento, execução e avaliação;

- a realização de reuniões para o pré-planejamento;

- a realização de reuniões multidisciplinares juntamente aos provedores de serviços para a definição das diretrizes e metas;

- tratativas diferenciadas para atividades críticas; 
- visão estratégica do evento e preocupação constante da alta-gerência com os eventos de parada do processo produtivo;

- a realização de reuniões para o alinhamento das atividades e a visualização dos recursos necessários, entre os supervisores de operação e manutenção, engenheiros e planejadores de manutenção, e representantes da gerência;

- programação das intervenções, nivelamento dos recursos, e elaboração dos cronogramas com o auxílio de softwares;

- a distribuição das responsabilidades e atividades entre os envolvidos;

- o acompanhamento estatístico do desempenho na fase de execução;

- a realização de reuniões para avaliação ao final do evento - com a finalidade de relacionar os principais itens para a próxima Parada, identificar os pontos fortes e as falhas, elaborando planos de ações para evitar reincidências.

Além disso, para as indústrias papeleiras, nota-se que o estabelecimento de métodos claros para o gerenciamento de todas essas variáveis e atividades, os aspectos comportamentais envolvidos, a aplicação da EM nestes momentos, as interfaces entre a manutenção do dia-a-dia com as intervenções e atividades de parada da planta, bem como alguns aspectos inerentes ao processo de produção, entre outros, são fatores que merecem uma abordagem mais adequada e voltada a uma visão ampla e estratégica da política de manutenção adotada.

Contudo, a união das idéias contidas nos trabalhos apresentados, além de algumas ferramentas observadas, podem ajudar na busca pelo aperfeiçoamento e padronização na forma de gestão desses eventos, bem como no estudo e ações sobre os riscos identificados no momento das intervenções.

\subsection{Uma Verificação na Prática - Parada Geral 2001 da VCP_LA}

Para a observação de um evento de parada planejada num ambiente empresarial real, e com isso a identificação, reunião e organização de todas as atividades e ações para a sistematização de seu gerenciamento e controle, serão 
apresentados todos os detalhes do planejamento e execução da PG2001, empreendimento anual realizado em junho do mesmo ano na VCP_LA, Unidade fabril descrita no item 2.3 deste trabalho. Também, serão relacionados e analisados alguns resultados específicos desta Parada, visando considerações sobre a importância de alguns fatores observados como fundamentais para seu sucesso.

\subsubsection{Visão geral do ambiente de verificação}

Como detalhado no item 2.3.1 do presente trabalho, a VCP_LA tem uma estrutura organizacional dividida em CT, coordenadas de forma centralizada por uma gerência geral, como representado na figura 2.3. Três destas células são produtivas e têm seus processos interligados e interdependentes: Célula Recuperação e Utilidades (CRU), Célula Celulose (CPC) e Célula Papel (CPP).

Assim, é importante esclarecer que a verificação prática ocorreu focada na CRU, que compreende os processos de recuperação química, produção de utilidades e tratamento de poluentes, estando subdividida administrativamente em três times de trabalho, cujos líderes respondem a um coordenador. O Time Recuperação e o Time Utilidades são responsáveis pela operação dos processos produtivos desenvolvidos, e o Time Manutenção dá suporte técnico e especialista aos mesmos, sendo o elo de ligação com as outras CP junto à Célula de Apoio Técnico (CAT).

O gerenciamento, planejamento e controle de paradas planejadas é de responsabilidade do Time Manutenção, composto por profissionais de elétrica, instrumentação, mecânica e planejamento. Esses, são liderados por supervisores, especialistas e um gestor chamado de "Facilitador", como mostra a figura 4.1. Neste caso específico, nota-se também o apoio da CAT, envolvendo profissionais de automação, inspeção e engenharia de manutenção.

Como características gerais da forma de gestão da manutenção utilizada na CRU, destacam-se: uma forte política de manutenção voltada a confiabilidade e a disponibilidade, a gestão compartilhada da produção, a valorização e capacitação do homem, a aplicação de práticas voltadas a qualidade e produtividade e o suporte de sistemas informatizados de apoio. 


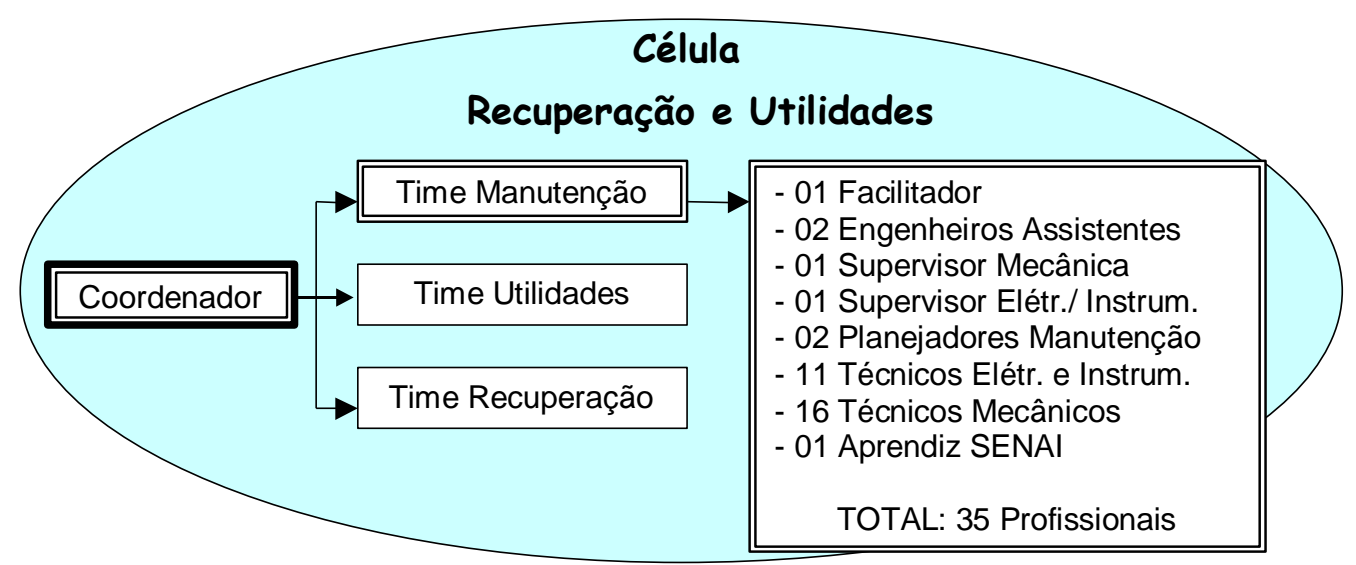

Figura 4.1 - Detalhe da estrutura organizacional da CRU e Time Manutenção.

A estratégia de intervenções nas plantas fabris da CRU compreende:

- Monitoramento contínuo dos equipamentos e sistemas

- Intervenções em Momentos de Oportunidade (MO)

- Paradas Planejadas Setoriais - Periódicas (PS's)

- Paradas Planejadas Gerais - Anuais (PG's)

Contudo, deve-se ressaltar que a VCP encara a PG como um dos grandes empreendimentos do período, nesse caso anual, sendo esse o principal evento para intervenções nos equipamentos e instalações, devido ao cessamento total da produção de celulose, bem como a redução da capacidade de produção de papel.

\subsubsection{Impactos e interfaces entre os processos}

Nas plantas de produção das utilidades, a estratégia de intervenções utilizada compreende o monitoramento contínuo, as PS's, as intervenções em MO e uma parada "completa" de todas as plantas de aproximadamente um dia durante a PG, momento chamado de "Parada Fria" (PF). Sem dúvida, este é um momento crucial para o sucesso na realização de um evento desse porte no setor, merecendo cuidados específicos diante a quantidade de atividades críticas envolvidas num curto espaço físico e período de tempo.

Quando se tem uma parada setorial ou completa da área de utilidades, a produção de elementos vitais para o funcionamento das áreas administrativas e 
produtivas é cessada, bem como o tratamento de resíduos, causando impactos representativos para toda a fábrica, destacando-se: água de fábrica e de selagem, tratamento de efluentes, geração de vapor, ar comprimido e distribuição e geração de energia elétrica. A essa interdependência dá-se o nome de "interface".

Além disso, existem impactos pontuais como o tratamento da água para alimentação das caldeiras, realizadas nas plantas de Osmose e Desmineralização, e a geração de parte do VAP, VMP e VBP, necessários para diversas etapas dos outros processos: cozimento da celulose, secagem do papel, Evaporação, aquecimento de equipamentos e sistemas na planta de celulose e nas máquinas de papel.

Face a isso, observa-se que normalmente as paradas de produção nessas áreas podem resultar na inviabilidade de outras inter-relacionadas.

Nesse contexto, as principais intervenções e atividades que tornam as PG’s imprescindíveis às plantas da área de produção de utilidades são:

- Limpezas operacionais e inspeções na parte de pressão das CF;

- Reparos e inspeções em sopradores de fuligem, Precipitadores Eletrostáticos (PE's) e outros acessórios;

- Reparos em tubulações e dutos;

- Reparos e testes em válvulas e tanques de alta pressão temperatura;

- Inspeções e reparos em motores, ventiladores e bombas;

- Troca e limpeza de filtros;

- Limpezas e inspeções em tanques de efluentes;

- Manutenções preventivas em turbinas, geradores e compressores;

- Manutenções preventivas em subestações e transformadores;

- Manutenções detectivas em Centrais de Controle de Motores (CCM), sistemas de emergência etc.

Não menos relevante, nas plantas que compõem o processo de recuperação química, a estratégia de intervenções utilizada também compreende o monitoramento contínuo, as paradas setoriais e as intervenções em momentos de oportunidade. Entretanto, esses processos têm uma participação mais significativa na PG, em termos de volume de trabalho, já que normalmente se constituem no "caminho crítico". 
Também, deve-se notar que as paradas nesse processo ocorrem obrigatoriamente em conjunto com a planta de produção de celulose, devido ao "ciclo fechado" caracterizado no item 2.3.3 deste trabalho, onde ocorrem a recuperação de resíduos e poluentes, a produção licor branco para a etapa de polpação da celulose, o reprocessamento do cal para utilização na planta da Caustificação e o tratamento de gases concentrados, condensados e de combustão.

Ainda, pode-se destacar a produção de vapor, utilizado na geração de energia elétrica, cozimentos, aquecimentos e secagens, e do $\mathrm{CO}_{2}$ fornecido à planta $S M I$ para a produção do $P C C$ enviado as MP.

Por fim, as principais intervenções e atividades, que tornam as PG's imprescindíveis nas plantas fabris, do ciclo de recuperação química são:

- Limpezas operacionais e inspeções na parte de pressão da CR;

- Reparos e testes em válvulas e tanques de alta pressão e temperatura;

- Inspeções, testes e reparos em equipamentos e sistemas de segurança operacional e isolamentos refratários;

- Reparos e limpezas em tubulações, dutos, tanques de licor e ambientes de alta temperatura e pressão;

- Reparos e inspeções em motores, ventiladores, bombas, PE’s e balões de alta pressão;

- Substituição e reparos de acessórios como sopradores de fuligem, bicas de fundido, limpadores de ar, queimadores etc.

\subsubsection{O desenvolvimento da Parada Geral}

Neste item serão evidenciados os aspectos principais do desenvolvimento da PG2001, onde foram envolvidas as plantas da CRU, CPC e de CPP. O enfoque no presente trabalho será dado para as atividades e intervenções realizadas sob responsabilidade da CRU, sendo que as tratativas administrativas comuns e as interfaces técnicas com as outras CP também serão abordadas.

Mesmo obtendo indicadores, historicamente, que demonstram uma otimização contínua dos recursos e uma melhora na eficiência e eficácia da equipe de 
manutenção nos últimos eventos de PG, a VCP_LA não possui e nem aplica uma sistemática específica e padronizada para o seu gerenciamento, sendo que nem sempre as CP's utilizam as mesmas práticas, técnicas e ferramentas, ou seja, não há um padrão definido e comum a ser seguido, o que dificulta uma gestão efetiva e centralizada do evento. Apesar disso, observa-se um conjunto de diretrizes para a realização das PG's.

Na PG2001, pôde-se notar claramente duas fases: o "planejamento do evento" e a "realização e avaliação da Parada". A seguir, serão apresentados todos os detalhes de ambas.

\subsubsection{O planejamento do evento}

As principais atividades observadas nesta fase são: um pré-planejamento macro; o estabelecimento de desafios; a definição e o detalhamento dos reparos e caminhos críticos, a distribuição de responsabilidades, a realização de reuniões de gerenciamento, a contratação de serviços e mão de obra; a aquisição de sobressalentes e demais recursos materiais; a emissão de informativos; e o planejamento final da parada. A seguir, seguem os detalhes específicos de cada atividade:

\section{O pré-planejamento macro:}

Neste momento, buscou-se trabalhar com três fatores: o custo da parada, o tempo de indisponibilidade total e os principais reparos e atividades necessárias. Para esses fatores, foram apresentadas metas junto à Gerência Geral da Unidade.

O valor orçado para a Parada, neste caso, foi definido juntamente ao orçamento do ano, ou seja, com muita antecedência. Este valor foi baseado em uma média histórica, com maior peso para as ultimas edições deste evento, e tomando-se os devidos cuidados quanto aos reajustes das tarifas inflacionarias ou cambiais. Coube as pessoas diretamente envolvidas com o evento adequar as necessidades à esses valores, buscar a otimização e a redução desses gastos, bem como justificar e alavancar mais recursos quando necessários.

Também, foi previsto um período base para a realização do evento, o 
qual pôde ser ajustado após a definição das principais atividades e caminhos críticos. Um primeira previsão do tempo total da parada foi baseada em dados históricos e necessidades pré-visualizadas para o evento.

Como principais diretrizes e metas para a PG2001 foram apresentadas:

- Data de início: 18/06/2001

- Parada Geral Unidade - Prazo: 10 dias

- Parada Fria CRU - Prazo: 20 horas (em 20/06/2001)

- Caminho crítico CRU - Prazo: 160 horas

- Valor Orçado CRU: R \$ 1.570.000,00 (materiais e serviços)

Obs.: Esse valor faz parte do orçamento anual de manutenção da CRU, e não contempla os investimentos em novas instalações.

Finalmente, já neste primeiro encontro foram revistas as necessidades inicialmente apontadas ao final da Parada anterior, bem como incluídas novas. Foram reunidas as pessoas-chaves envolvidas no processo (de várias especialidades e áreas), e com uma antecedência de cinco a seis meses do inicio do evento.

O estabelecimento de desafios:

Foram definidos desafios gerais e específicos, estando alguns deles relacionados a seguir.

Desafios gerais:

- Parada Geral da Unidade - Prazo proposto: 8,6 dias (redução de 14\%)

- Valor proposto - CRU: R\$1.490.000,00

Obs.: Redução de 5\%, como estabelecido para todas as CP.

Desafios específicos - CRU:

- Caminho crítico - Prazo proposto: 134 horas (redução de 15\%)

- Parada Fria - Prazo proposto: 18 horas (redução de 10\%)

- Indicadores de manutenção (de acordo com o anexo A) Produtividade, Utilização e Eficiência $\geq 95 \%$

- Retrabalhos e acidentes - ZERO

É importante salientar que todos os desafios foram analisados quanto a sua real possibilidade de atendimento, junto a todos os envolvidos direta ou 
indiretamente com as atividades e intervenções.

A definição e o detalhamento dos caminhos críticos e demais atividades:

Para a definição e detalhamento dos caminhos críticos, os gerentes, as equipes de planejamento de manutenção das células e o Facilitador da CAT, neste caso o coordenador de Parada, se reuniram no mês de dezembro de 2000. Caracterizando o caminho crítico, foram identificadas quatro atividades a serem realizadas em sequiência na $\mathrm{CR}$ :

- Montagem de andaimes nos internos da caldeira;

- Limpezas e testes operacionais;

- Inspeções internas e repinagem nas paredes da fornalha;

- Desmontagem e retirada dos andaimes.

Estas atividades interdependentes são o "carro-chefe" da PG, e todas as outras serão planejadas e executadas dentro do prazo necessário para as mesmas. Com essa definição, o cronograma master foi elaborado e divulgado ainda no mês de dezembro, como observa-se no anexo B.

Para auxílio à essa atividade também foram utilizados o Relatório Final da PG2000. Neste momento, notou-se uma primeira avaliação e preocupação quanto aos fatores segurança e meio ambiente, sendo que estes prevaleceram na definição do tempo total de indisponibilidade e nos custos envolvidos.

Após a definição da atividade de maior duração do evento, as equipes de manutenção e operação da CRU reuniram-se para a definição e análise das demais atividades e intervenções necessárias, utilizando: o Relatório Final da PG2000, manutenções corretivas e preventivas em carteira, melhorias e modificações estabelecidas no planejamento estratégico, inspeções e testes legais, limpezas operacionais de campanha, bem como ações elaboradas na realização de FTA, FMEA, RCFA, Ciclos PDCA e APP.

Com isso, todos os serviços previstos foram detalhados, a fim de obter bases para a visualização macro dos recursos necessários, seu nivelamento, verificação das interfaces, interdependências, otimizações e reajustes nos desafios. Em alguns momentos, profissionais de outras áreas foram envolvidos, com destaque para suprimentos, compras, segurança e meio ambiente. 
Como softwares de apoio são utilizados o MANTEC e o MS-Project, sendo que este último têm funções de PERT-CPM e diagramação, e o primeiro históricos de equipamentos e instalações, módulos para programação, previsão de recursos, controle de mão-de-obra e gestão da evolução dos trabalhos.

Para atividades críticas, esse detalhamento foi utilizado por equipes multidisciplinares específicas, que puderam se aprofundar em cada detalhe e trabalhá-los de forma conveniente.

A distribuição de responsabilidades:

Buscando ações efetivas para cada atividade e intervenção na planta fabril, foi definido um organograma geral envolvendo todas as células, que define claramente as responsabilidades de todos durante a PG, como exemplo no anexo C.

Indicam-se grupos ou pessoas que tem a responsabilidade de centralizar as informações e promover a alocação dos diversos recursos necessários para um perfeito andamento das atividades, ou seja, administra-las desde o seu planejamento até sua execução. Normalmente têm-se dois tipos de variáveis: as "administrativas", que por vezes envolvem as várias áreas e subprocessos, e as "técnicas", referentes as intervenções nos equipamentos e processos específicos.

Para variáveis administrativas escolhem-se "pessoas chaves" que já estão ligadas a essas atividades constantemente. Já para as variáveis técnicas, ou seja, para as intervenções e atividades de campo definem-se pessoas ligadas diretamente ao processo, já que estas fazem parte do dia-a-dia dos equipamentos envolvidos.

Se necessário, dentro de cada célula podem ser elaborados organogramas ou listas de responsabilidades com maiores detalhes. Cada responsável ou grupo de trabalho gerencia a atividade ou intervenção completamente, desde a previsão das necessidades até a execução e avaliação, provendo os recursos de apoio, padronizando as ações, acompanhando a evolução do serviço e analisando os desvios e falhas.

A realização de reuniões de gerenciamento:

$\mathrm{Na}$ fase de planejamento foram observados três tipos de reuniões:

- Reuniões de gerenciamento global: realizadas com periodicidade mensal, divulgadas e agendadas pelo coordenador da Parada. 
Envolvem todas as CP e pessoas-chaves;

- Reuniões de gerenciamento por CP ou atividade: ocorreram de forma esporádica, sendo que com a aproximação do início do evento foram mais freqüentes;

- Reuniões e "Integrações" com as empresas provedoras de serviços: como principais objetivos destes encontros têm-se a padronização das informações específicas do ambiente de trabalho e da cultura da Empresa, as questões contratuais, as normas de segurança etc.

A contratação de serviços e mão de obra:

Para essa atividade, observou-se o suporte da equipe de planejamento da CAT, devido a necessidades estratégicas como a otimização dos recursos comuns entre as Células, a contratação de maiores quantidades a menores custos, avaliação dos recursos e serviços contratados de forma padronizada etc.

Na VCP_LA são utilizados quatro tipos de contratos: por administração, por preço unitário, por pacote e especialista.

A aquisição de sobressalentes e demais recursos materiais:

Todos os recursos materiais vislumbrados foram contemplados nas OS's planejadas no sistema MANTEC, quando diretamente envolvidos com atividades e intervenções na planta fabril, ou requeridos em documentos específicos no $S A P$ pelos planejadores de manutenção. Esses sistemas garantem a aquisição desses recursos de uma forma automática, estabelecendo uma rede de suprimentos que também é gerenciada por equipes específicas.

A emissão de informativos gerais e de segurança:

Observou-se como principais formas de comunicação utilizadas: folhetos, cartazes e faixas.

As faixas e cartazes foram utilizadas para informações específicas dos locais, como avisos de segurança, trânsito de veículos, horários de refeições das contratadas, quadros de acompanhamento horas extras etc.

Os folhetos para informações de interesse geral, destacando normas de 
segurança, organização e higiene, como exemplo na figura 4.2.

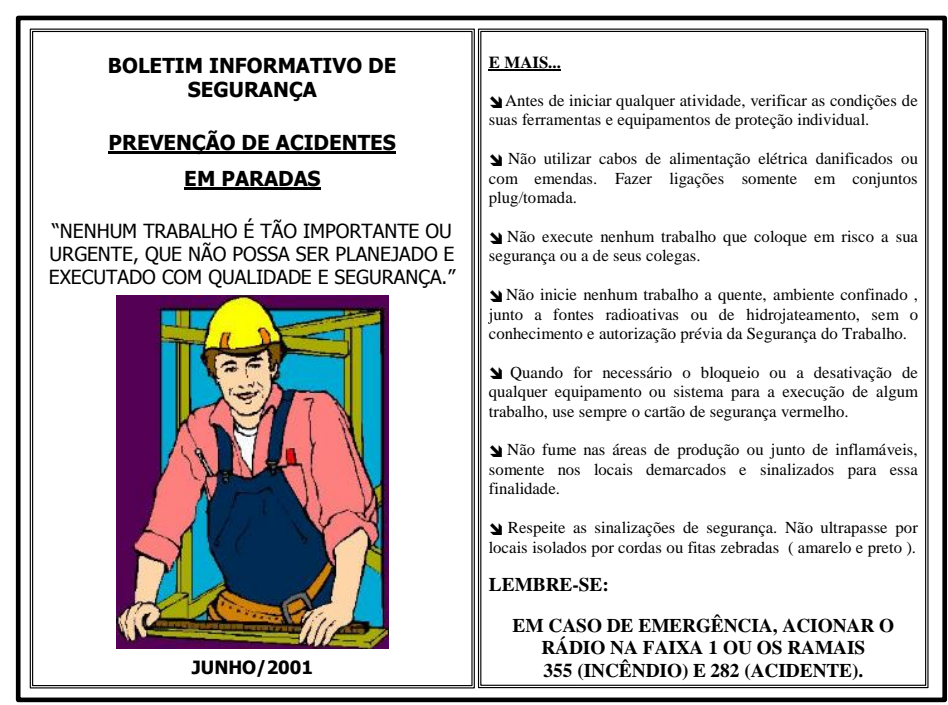

Figura 4.2 - Folder de Segurança da Parada Geral 2001.

O planejamento final da Parada:

Finalmente, diante a proximidade do evento verificou-se seu planejamento e preparativos finais, destacando-se algumas atividades, como descritas a seguir.

Para a programação das atividades e a emissão dos cronogramas, todas as ações foram planejadas em OS no sistema MANTEC, como ilustra a figura 4.3, relacionadas em cronogramas de atividades no sistema MS-Project, bem como os recursos requisitados através do sistema $S A P$. Nesse caso, os planejadores de manutenção são os responsáveis por esses procedimentos.

É importante ressaltar que esses softwares integrados facilitam as interfaces entre as áreas, alimentam a rede de suprimentos, padronizam as atividades, dão suporte aos contratos, garantem a agilidade e flexibilidade no planejamento e aquisição dos recursos etc.

Quanto aos preparativos finais para as intervenções, utilizou-se o suporte das ARP (como ilustra o anexo D) e os Ciclos PDCA, onde todos os passos e riscos potenciais foram tratados e planos de ação definidos, restando portanto a execução dos mesmos.

Os preparativos foram iniciados com a antecedência adequada para cada ocasião, sendo alguns gerais e outros específicos:

- a realização de integrações e treinamentos; 
- a disponibilização dos recursos e equipamentos nos locais de trabalho;

- pré-montagem de grandes equipamentos e estruturas;

- desmontagem de isolamentos térmicos;

- montagem de andaimes e plataformas de trabalho etc.

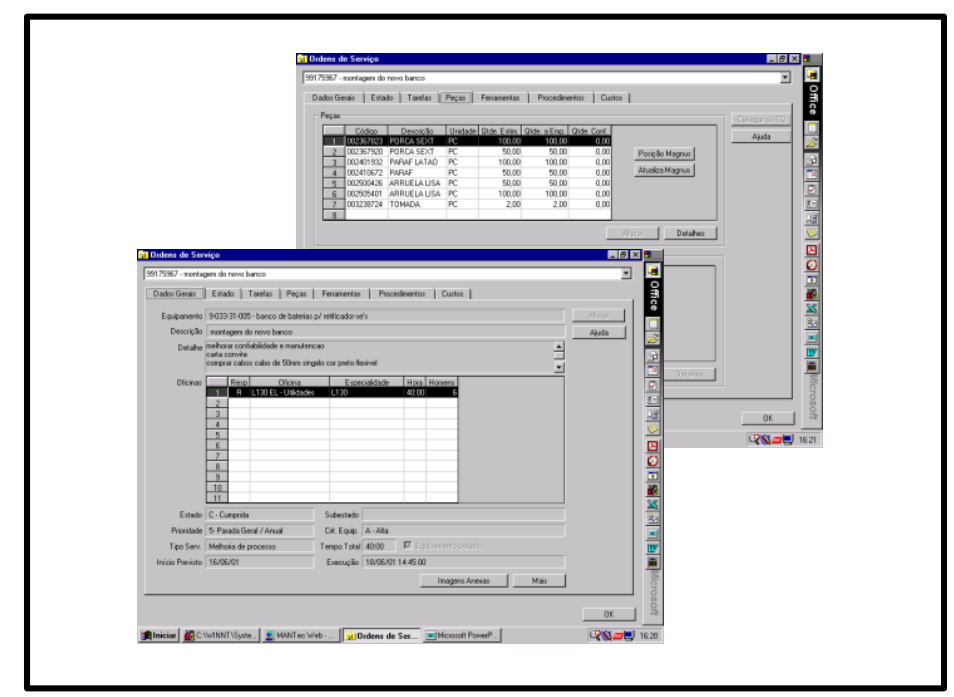

Figura 4.3 - Ordem de Serviço da Parada Geral 2001.

Chamou a atenção aqui a falta de cronogramas para as atividades que compõem os preparativos, dado o grande volume de serviços necessários. Também, a realização de encontros com os profissionais das provedoras de serviços, para uma ambientação no local de atuação, antes do início do evento é recomendável.

\subsubsection{Realização e avaliação do evento}

No momento da realização da Parada, observou-se algumas atividades principais, como: emissão das OS's e liberações de trabalho; recebimento dos recursos humanos, materiais e de apoio; parada da planta fabril; a execução de todas as atividades e intervenções; reuniões de acompanhamento; alimentação do software de manutenção; partida da planta fabril; período de estabilização e alinhamento da produção; brainstorming para o levantamento dos aspectos relevantes; reunião gerencial de avaliação da Parada; e emissão do Relatório Final da Parada. Todas essas atividades são descritas a seguir: 
Emissão das OS e liberações de trabalho:

Todas as OS foram liberadas no sistema MANTEC, impressas e entregues aos executantes ou responsáveis que, neste caso, são da própria VCP, sendo registradas 952 OS referentes a CRU nesta PG. Esse documento é essencial para a execução dos serviços, sendo que seu número é necessário para a emissão das liberações de segurança, ficando registrado no cartão de segurança vermelho, que garante a não operação dos equipamentos e sistemas no momento das intervenções.

Além disso, em ambientes confinados e de características especiais foram feitos check-list e anexados em lugares visíveis e próximos as entradas ("bocas de visita"). Técnicos de segurança e bombeiros são os únicos autorizados a emitir esses documentos, padronizados na VCP_LA.

Recebimento dos recursos humanos, materiais e de apoio:

Todos os recursos materiais e de apoio foram verificados através de check-lists no momento de sua chegada, em um local apropriado e antes de seguirem para as áreas solicitantes. Foram formados grupos contendo um técnico de segurança e outro da(s) especialidade(s) necessária(s), como por exemplo: elétrica, mecânica e instrumentação.

As inconformidades foram registradas e os fornecedores contatados para as adequações ou substituições necessárias.

Quanto aos profissionais contratados, foram realizadas as "Integrações", onde são transferidas informações gerais, procedimentos e normas de segurança da empresa, particularidades do ambiente de trabalho e padrão de comportamento esperado. As áreas de treinamento e desenvolvimento, segurança e CAT, promoveram esses eventos em conjunto e emitiram informativos com os planos.

Após as Integrações, os profissionais seguiram para as Células para ambientação, distribuição das equipes e preparativos finais. Foram registrados 535 profissionais contratados para atuação nas plantas da CRU, onde 481 passaram pelas Integrações (sendo que o restante já havia participado em outras oportunidades), que somaram 49 no total da Unidade. 
Parada da planta fabril (cessamento da produção):

Desde o início das reduções de processamento até a completa parada da planta de recuperação química registrou-se aproximadamente 11 horas, sendo considerado normal um período de 8 a 12 horas.

Todas as manobras e desligamentos foram realizados de acordo com os padrões estabelecidos. Nenhuma anormalidade ou acidente foi registrado.

Execução de todas as atividades e intervenções:

Todas as atividades de Parada e intervenções foram realizadas: inspeções, limpezas, manutenções, modificações, melhorias etc.

Por vezes, surgiram atividades imprevistas observadas nas inspeções e limpezas. Essas, foram analisadas quanto sua real necessidade e viabilidade antes de seu planejamento e execução.

Reuniões de acompanhamento:

Durante a Parada, foram observadas as seguintes reuniões:

- Reuniões gerenciais diárias para o acompanhamento de desempenho e análise das tendências - envolvendo as pessoas chaves, chefes de setores, representantes dos grupos de trabalho e das contratadas, gerentes locais e diretores corporativos.

- Reuniões setoriais (por CT) - na CRU, por exemplo, ocorriam diariamente, sempre uma hora antes das reuniões gerenciais.

- Reuniões em grupos multidisciplinares para o acompanhamento de serviços imprevistos - novos grupos foram formados, após sua validação para execução.

Alimentação do software de manutenção:

Durante a PG, observou-se:

- fechamento das OS's no MANTEC, procedimento parte da execução do serviço, sendo realizado pelos técnicos de manutenção;

- atualização dos tempos reais observados nos cronogramas do $M S$ Project, realizado pelos planejadores de manutenção; 
- atualização de planilhas específicas, como: horas-homens realizados, horas-extras, refeições, acidentes, interrupções etc., atividades realizadas pelas pessoas chaves ou grupos de trabalho;

Partida da planta, período de estabilização e alinhamento da produção:

Para o retorno dos equipamentos e sistemas à condição de operação normal, na planta de recuperação química, registrou-se aproximadamente 22 horas, sendo considerado normal um período de 24 horas.

Todas às manobras e desligamentos foram realizados de acordo com os padrões estabelecidos, sendo que nenhuma anormalidade ou acidente foi registrado. A evolução das atividades e parâmetros operacionais foram acompanhados e monitorados continuamente via SDCD pela equipe de partida.

Cerca de 12 horas depois das plantas estarem em "paralelo" (alinhadas em termos de processamento contínuo), atingiu-se a estabilidade nos processos. Até esse momento, a evolução dos parâmetros de operação foram acompanhados nos mínimos detalhes, a fim de identificar distúrbios na sua origem e atuar corretivamente com rapidez.

O fim da etapa de execução da PG foi decretado quando a "qualidade" do produto final se alinhou com o padrão estabelecido e desejado, verificado através de análises laboratoriais e leitura dos indicadores de operação.

Brainstorming para o levantamento dos aspectos relevantes:

Após a estabilização do processo e a normalização da qualidade do produto, os representantes dos grupos de trabalho, as pessoas chaves e os Facilitadores foram reunidos pelo coordenador de parada para o levantamento e verificação dos principais pontos de atenção observados, como:

- pontos fortes e fracos;

- metas e desafios alcançados;

- principais desvios e falhas;

- acidentes, condições e práticas abaixo do padrão;

- otimizações e ganhos obtidos;

- principais serviços realizados; 
- informações gerais do evento;

- status e tendências dos custos;

- recomendações e perspectivas para a próxima PG.

Antes desse encontro, várias informações foram colhidas junto aos executantes, profissionais contratados, grupos de trabalho e outras fontes, já que a participação das pessoas diretamente envolvidas na execução dos serviços e atividades é fundamental para a veracidade e assertividade dos pontos colocados acima.

Essas informações, em conjunto com as anotações de Parada, foram revisadas e validadas nesse brainstorming, que gerou como principal produto os dados para discussão na reunião gerencial de avaliação da Parada e o relatório final.

Reunião gerencial de avaliação da Parada:

Com os dados reunidos nas fases iniciais desta etapa, juntamente aos parâmetros de controle, gráficos, planos e cronogramas atualizados (com os apontamentos reais), tudo foi discutido e validado na reunião gerencial de avaliação.

Esse encontro reuniu as pessoas chaves, planejadores, facilitadores, coordenadores das CT, representantes dos grupos de trabalho e das contratadas, além dos gerentes locais e diretores corporativos, sendo organizada pelo coordenador de parada. Como produto dessa reunião, têm-se todos os dados necessários para a emissão do relatório final da Parada.

\section{Emissão do Relatório Final da Parada:}

Os planejadores de manutenção das CP deram o suporte necessário ao coordenador de parada para a emissão do relatório final.

Foi constituído um relatório, de aproximadamente 50 páginas, com todas as informações compiladas de forma clara e sintética conforme estrutura abaixo:

- resultados e informações gerais - período real, quantidade de serviços realizados, mobilização de pessoas, custos, estado geral das instalações etc. (como exemplo no anexo E);

- organograma oficial do evento;

- principais metas e desafios;

- custos finais e projeções (real x orçado) por célula; 
- cronograma master final e cronogramas das atividades críticas;

- Relatório de Parada Programada (como ilustra o anexo B);

- principais serviços por $\mathrm{CP}$;

- serviços de engenharia - modificações, melhorias e novos projetos;

- planilha de utilização de mão-de-obra das empresas contratadas;

- aspectos positivos e negativos por célula; e

- as principais ocorrências de segurança.

Após sua edição, o Relatório Final da Parada 2001 foi apresentado, registrado nos arquivos da Unidade, divulgado e encaminhado a alta direção da Empresa.

\subsubsection{Resultados da Parada e análises}

O principal objetivo deste item é a verificação e análise dos principais resultados obtidos na PG 2001. Para isso, primeiro serão apresentados os dados previstos (metas e desafios) e reais obtidos, sendo estes posteriormente comparados.

Face aos desafios lançados nas plantas produtivas da CRU, os principais resultados são relacionados na figura 4.4 .

\begin{tabular}{|c|c|c|c|c|c|}
\hline \multicolumn{6}{|c|}{ Planilha de Resultados - Parada Geral 2001} \\
\hline Amplitude & Item & Meta (M) & Desafio (D) & Realizado (R) & Desvio (DxR) \\
\hline \multirow{2}{*}{$\begin{array}{c}\text { Parada Geral } \\
\text { (Unidade) }\end{array}$} & Inicio & 18/Jun & 18/Jun & 18/Jun & - \\
\hline & Prazo & 10 dias & 8,6 dias & 7,6 dias & 1 dia \\
\hline \multirow{4}{*}{$\begin{array}{c}\text { Parada Geral } \\
\text { (CRU) }\end{array}$} & Prazo & - & 7 dias & 6,4 dias & 0,6 dia \\
\hline & Parada Fria & 20 horas & 18 horas & 18 horas & - \\
\hline & Caminho Crítico & - & 134 horas & 128 horas & 6 horas \\
\hline & Custos (R\$) & $1.570 .000,00$ & $1.490 .000,00$ & $1.754 .730,00$ & $264.730,00$ \\
\hline \multirow{5}{*}{$\begin{array}{l}\text { Indicadores de } \\
\text { Manutenção } \\
\text { (CRU) }\end{array}$} & Produtividade & - & $95 \%$ & $99 \%$ & $4 \%$ \\
\hline & Utilização & - & $95 \%$ & $99 \%$ & $4 \%$ \\
\hline & Eficiência & - & $95 \%$ & $100 \%$ & $5 \%$ \\
\hline & Retrabalhos & - & ZERO & 2 & 2 \\
\hline & Acidentes & - & ZERO & 6 & 6 \\
\hline
\end{tabular}

Figura 4.4 - Quadro de resultados finais da Parada Geral 2001. 
A seguir, é apresentada uma análise dos principais pontos observados nos resultados apresentados:

Parada Geral - Unidade e CPU:

A PG foi iniciada sem problemas e todos os trabalhos foram executados conforme planejado, obtendo-se um ganho no prazo total estabelecido de 1 dia em relação ao desafio e aproximadamente 2 dias sobre a meta da Companhia. Essa redução no tempo de indisponibilidade do processo foi eqüivalente a 2.835 toneladas de celulose, produção estimada em aproximadamente R\$1.600.000,00.

$\mathrm{Na}$ CRU, foi registrado um ganho de 0,6 dias face ao desafio de 7 dias, o que contribuiu definitivamente para esse resultado global.

\section{Parada Fria:}

A PF ocorreu dentro dos planos, sendo executada em 18 horas como o desafio estabelecido pela equipe. As 2 horas de ganho face a meta gerencial foi encarada como um belo resultado, devido a grande quantidade de serviços executados e empresas envolvidas num curto período, ressaltando-se a sinergia entre as equipes de operação e manutenção, e a realização de serviços imprevistos observados nas inspeções.

Caminho crítico:

As atividades que compõem o caminho crítico (montagem e desmontagem de andaimes, limpezas e testes operacionais, inspeções internas e repinagem nas paredes da fornalha da CR) foram realizadas em 128 horas, 6 horas a menos que o desafio.

Esse resultado torna-se expressivo em virtude de vários fatores agravantes, dentre eles: envolvimento de seis empresas contratadas, além das equipes de operação, manutenção, segurança e CAT (inspeções e testes).

Custos gerais:

Durante a etapa de execução da PG, sete serviços extras foram realizados, apontados em inspeções e complementações observadas. Como 
envolviam valores significativos, todos foram analisados quanto a real necessidade, viabilidade e oportunidade.

Dessa forma, obteve-se os seguintes valores:

- Custo real total $\quad-\mathrm{R} \$ 1.754 .730 .00$

- Despesas extras $\quad-\mathrm{R} \$ 238.600,00$

- Custo real relativo $-\mathbf{R} \$ \mathbf{1 . 5 1 6 . 1 3 0 , 0 0}$

Obs.: Custo real relativo - custo verificado em relação aos valores estimados na fase de planejamento, sem os custos das atividades imprevistas realizadas.

Comparando-se o custo planejado inicialmente com o real relativo verificado, nota-se o atendimento ao desafio estabelecido, com um desvio de apenas 1,75\% ( $\mathrm{R} \$ 1.516 .130,00 / \mathrm{R} \$ 1.490 .000 .00)$, sendo que obteve-se uma redução de aproximadamente $3,4 \%$ face a meta $(\mathrm{R} \$ 1.516 .130,00 / \mathrm{R} \$ 1.570 .000,00)$.

Além disso, deve-se lembrar que os ganhos obtidos na redução do prazo total da Parada minimizaram o impacto dessas despesas extras apontadas.

Indicadores de manutenção:

Os indicadores de performance de mão-de-obra de manutenção (Produtividade, Utilização e Eficiência), apresentaram resultados acima do esperado (cerca de 5 pontos percentuais em média).

Isso demonstrou o grau de assertividade alcançado nas etapas de planejamento e execução, bem como a eficácia da PG, com a otimização da utilização dos recursos e a redução dos tempos de indisponibilidade.

Retrabalhos:

Foram registrados apenas dois retrabalhos, número considerado excelente frente a enorme quantidade de atividades e serviços realizados durante a PG (só na CRU foram registradas mais de 500 OS).

Ambas as ocorrências foram verificadas em Gamagrafias realizadas por empresas especializadas na análise de solda em tubulações da parte de pressão da Caldeira de Recuperação, não resultando porém em atrasos relevantes.

Como esses serviços foram executados por uma empresa contratada, e 
sob inspeção especializada de outra, as mesmas foram responsabilizadas pelas falhas e envolvidas nas análises (FMEA, RCFA e FTA) para os esclarecimentos necessários.

Acidentes com danos materiais e pessoais:

Foram registradas duas ocorrências na CRU: um acidente com afastamento e um sem afastamento, ambos de pequena gravidade.

Diante da quantidade de pessoas e atividades envolvidas, como já observa-do, e face a média histórica de ocorrências, obteve-se um número inferior, o que demonstra o grau de conscientização alcançado por todos os envolvidos.

\subsubsection{Alguns fatores de risco observados}

Face as principais atividades, aspectos e desafios inerentes a CRU, foram observados vários fatores de risco potencial referentes à segurança, meio ambiente e custos. Como ilustração, têm-se alguns exemplos a seguir:

- desvios dos custos orçados;

- atrasos no prazo total da parada, caminhos críticos e PF;

- acuracidade nas medições e análises dos indicadores de performance de manutenção pré-estabelecidos;

- alta criticidade da logística e instalação de um transformador (4T);

- modificação na posição de um soprador de fuligem da CR;

- repinagem das paredes da fornalha da CR;

- troca de tijolos refratários do forno de cal rotativo;

- acidentes com pessoas, bens e meio ambiente etc.

Para o acompanhamento e controle desses fatores identificados, nem sempre foram constituídas ferramentas ou grupos específicos, de forma clara e padronizada. Mesmo com a verificação de bons resultados globais, como no item 4.4.4, nota-se que a falta de um padrão de ação e atuação, face ao caráter estratégico observado nessas ações, pode causar alguns distúrbios, trazendo impactos nos custos e prazos. 


\subsubsection{Considerações da verificação na prática}

Buscando-se ressaltar alguns aspectos importantes observados na prática, com o estabelecimento de pontos de atenção para o desenvolvimento da sistemática de manutenção proposta neste trabalho, têm-se algumas considerações:

i) De forma geral, notou-se três questões fundamentais como pontos de partida para a PG2001: a apresentação das metas e o estabelecimento dos desafios, com a antecedência adequada (no caso 6 meses), e a definição clara do caminho crítico;

ii) Também, observou-se que a utilização de históricos dos equipamentos e eventos, softwares para a gestão da manutenção de rotina e ações definidas por ferramentas de análises de falhas, problemas e riscos potenciais, foram fundamentais para a filtragem das atividades e intervenções a serem realizadas durante a PG;

iii) A sinergia entre as equipes de operação e manutenção, obtida com a disseminação de conceitos e práticas de $T P M$ e $5 S$, bem como a utilização de softwares com módulos de gestão da manutenção foram fatores essenciais para a assertividade no planejamento das atividades e nivelamento dos recursos;

iv) Fica clara a necessidade do estabelecimento de algumas formas de controle para o monitoramento dos fatores de risco potencial observados, principalmente devido a sua importância estratégica, pois promove uma visualização clara, sintética e padronizada dos principais pontos de atenção durante o evento;

v) Devido ao sucesso em casos específicos, é importante a formação de grupos de trabalho para todas as intervenções críticas e estratégicas, pois podem garantir uma análise detalhada e especialista para cada caso, bem como reduzir a possibilidade de atrasos e falhas;

vii) Para a obtenção de um monitoramento ágil e flexível de todas as ações, é fundamental a intensificação na realização de reuniões sistemáticas e periódicas durante todas as etapas do evento, principalmente quando estão envolvidas plantas e sub-processos diferentes e interrelacionados, bem como atividades complexas e de grande porte;

viii) Apesar da utilização da mesma equipe operacional junto às diferentes equipes 
de manutenção e segurança para os momentos de parada e partida da planta ter se mostrada uma prática viável, é oportuna a formação de uma equipe única, devido a complexidade e complementaridade das ações de parada e partida;

ix) Como momento crítico da Parada, destaca-se o momento da partida das plantas e do processo, onde o acompanhamento contínuo do período de estabilização e o estabelecimento de indicadores para a certificação do alinhamento da produção pósparada em termos de qualidade do produto são questões fundamentais;

x) Por fim, como pontos finais que merecem uma atenção diferenciada, têm-se:

- estabelecimento de critérios específicos para avaliação dos provedores de serviços;

- a constituição de um painel central de informações durante o evento, de preferência em uma área comum, onde possam ser colocados os dados gerais, evitando assim boatos sobre acidentes, desvios e atrasos;

- a definição de uma agenda para reuniões gerenciais e específicas, com antecedência;

- a criação de check-lists para a revisão de ações e procedimentos, principalmente de parada e partida da planta;

- a formalização de critérios para verificação das atividades e intervenções em campo, especialmente às executadas por terceiros;

- o registro sistemático de informações durante a Parada em um livro único; e

- a necessidade de um maior aprofundamento quanto a análise crítica do método, práticas e ferramentas utilizadas para o gerenciamento e controle da PG.

Contudo, essas considerações verificadas na prática em conjunto com as observações das abordagens teóricas, como descrito no item 4.2, formarão as bases e darão subsídios para o desenvolvimento da sistemática de manutenção para o gerenciamento e controle de paradas planejadas, como proposto nos objetivos deste trabalho. 


\section{CAPÍTULO 05}

\section{UMA SISTEMÁTICA DE MANUTENÇÃO PARA O GERENCIAMENTO DE PARADAS PLANEJADAS}

\subsection{Introdução}

Como abordado nos itens 1.3 e 1.4 do capítulo 1 , as paradas planejadas constituem o tipo de intervenção mais desejado atualmente pelas empresas do setor papeleiro, devido às características competitivas de mercado e da alta tecnologia embarcada no processo produtivo.

Em processos contínuos como esse, as paradas planejadas configuram-se como um diferencial estratégico, pois seu sucesso resulta em uma maior confiabilidade operacional e num gradativo aumento da produtividade, alicerçadas numa linguagem universal: redução das perdas e otimização dos custos do processo.

No entanto, para que esse sucesso seja alcançado, muito planejamento e disciplina são necessários, bem como metas e formas de controle bem definidas. Esses eventos são constituídos de inúmeros detalhes, referentes a fatores como: a definição e a contratação dos recursos de mão-de-obra e de apoio, a gestão das atividades de centenas de pessoas contratadas, as interfaces dos diversos subprocessos, o planejamento de todas as intervenções, a elaboração dos cronogramas, a gestão da logística, o acompanhamento estatístico do desempenho durante a execução das atividades e a gestão dos recursos financeiros disponíveis.

Face à grande quantidade de atividades envolvidas, deve-se questionar a realização de todos os trabalhos, haja vista que com a parada da planta fabril todas as intervenções tornam-se possíveis, mas não imprescindíveis. 
Segundo pesquisa realizada por OLIVERSON* apud TAVARES (1999: 18):

"Em grandes empresas americanas foram revisadas mais de 15.000 ordens de serviço, onde se observou que $47 \%$ dos serviços poderiam deixar de ser executados, o que correspondia, nessas empresas, como gastos desnecessários de \$18 milhões em mão de obra e material".

Nesse ambiente, após a definição das atividades a serem realizadas, todas as suas variáveis devem ser tratadas detalhadamente e com o máximo de cuidado possível. Para isso, o desenvolvimento de procedimentos de análise, planejamento, controle e avaliação é indispensável, devido ao grau de disciplina necessário durante a etapa de planejamento e ao clima tenso e desgastante na execução.

Também, deve-se observar que nesses eventos alguns milhões de reais são gastos em poucos dias, ou até em algumas horas, o que denota a importância da disseminação de uma visão estratégica e sistêmica a todos os envolvidos. Como exemplo, na VCP_LA, tem-se um investimento médio nos eventos de PG de cerca de $35 \%$ do orçamento anual de manutenção previsto no início do período, os quais são consumidos em aproximadamente dez dias de parada.

De forma geral, como pontos importantes de atenção, destacam-se a elaboração de planos de ação para as necessidades apontadas pelas equipes de operação e manutenção, a prevenção dos riscos potenciais durante a realização das atividades, e a otimização de alguns parâmetros estratégicos como custos, indisponibilidade, confiabilidade e segurança operacional após o retorno.

Normalmente, as equipes de planejamento e engenharia de manutenção, têm como parte de suas atribuições a responsabilidade da gestão desses eventos, centralizando as informações, envolvendo as pessoas necessárias, provendo os recursos adequados, e acompanhando os desvios e os indicadores de desempenho junto aos gerentes. Um forte diferencial comentado por vários autores é a "equipe de planejamento e programação de manutenção", apresentada como um alicerce para o sucesso de grandes reparos. NAGAO (1998:59) escreve que:

* OLIVERSON R. J. (1997). Preveantable Maintenance Costs More Suspected. Manintenance Techology - September, apud TAVARES (1999). Administração Moderna da Manutenção. Rio de Janeiro, Novo Polo Publicações. p.18. 
“... principalmente em indústrias de processo contínuo, um bom módulo de planejamento de paradas das unidades é fundamental.(...) As paradas nestas indústrias podem significar um período intenso de atividades com centenas e até milhares de pessoas (pessoal próprio e prestadores de serviços) trabalhando em conjunto dentro de um prazo muito bem definido."

Em razão disto, complementa NAGAO (1998:59):

“... o sucesso da realização de uma parada depende de uma área de coordenação eficaz onde custos, qualidade dos serviços e prazos são essenciais."

Finalmente, deve-se lembrar que esses eventos são fundamentais para a garantia da confiabilidade operacional do processo, sendo que atualmente uma hora de produção de celulose e papel significa cerca de \$25 mil dólares e, dessa forma, tudo tem de ser feito à fim de evitar as indesejáveis paradas imprevistas, as quais aumentam a probabilidade da ocorrência de acidentes, comprometem a qualidade dos produtos, inviabilizam a otimização dos recursos para a intervenção etc. Também, por essa razão financeira a PG deve ser bem planejada e executada.

Face à essas necessidades, é proposto o desenvolvimento de uma sistemática de manutenção para o gerenciamento e controle de paradas planejadas gerais em processos de produção de celulose e papel, buscando-se definir formas adequadas para a identificação clara e otimização de suas etapas, a partir de uma visão estratégica gerencial e voltada a melhoria contínua, ao máximo de economia de tempo e dinheiro, ao mínimo de indisponibilidade e retrabalhos, e a uma concreta preocupação com segurança e meio ambiente.

De forma geral, esta sistemática envolverá a definição de metas, desafios e a identificação de formas de controle, caracterizadas pelos fatores de risco, diante de uma gestão da manutenção voltada ao processo produtivo e fundamentada numa forte política de manutenção, bem como em programas e técnicas da qualidade, como ilustra a figura 5.1. Também, estará baseada no conhecimento disponível na literatura pertinente de manutenção e na prática empresarial.

Para o desenvolvimento dessa sistemática, torna-se necessária à aplicação de técnicas específicas, alicerçadas em uma forma de gestão da manutenção que pregue o contínuo aperfeiçoamento técnico e cultural dos profissionais, maior qualidade e eficiência nas intervenções, melhores índices de confiabilidade e disponi- 


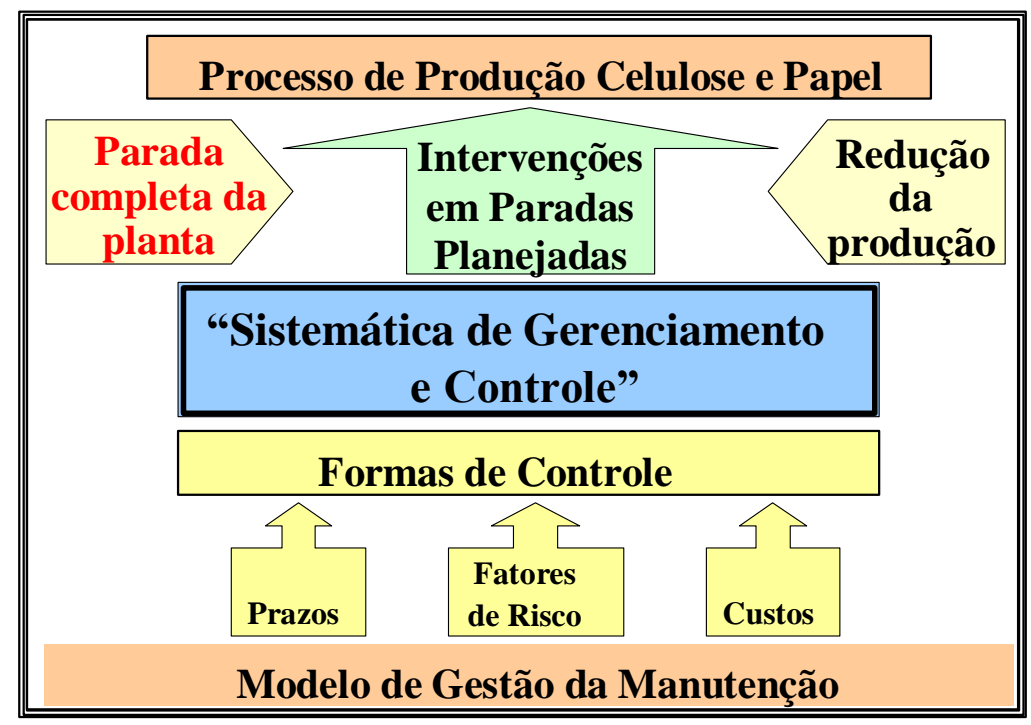

Figura 5.1 - Visão geral do ambiente de desenvolvimento da sistemática de manutenção proposta.

bilidade do processo, comprometimento das pessoas, trabalho em equipe, e otimização dos recursos e custos, entre outros aspectos fundamentais.

Assim, o que se propõe é o desenvolvimento de uma sistemática que proporcione um gerenciamento dinâmico, efetivo e estratégico das Paradas Planejadas. Para isso, cuidados especiais e disciplina são indispensáveis quanto às tratativas de todas as variáveis envolvidas, atividades de manutenção e operacionais, controle das metas e medição de performance, entre outros.

Contudo, o estabelecimento de um ambiente organizacional voltado ao conhecimento e à qualidade, a promoção da gestão compartilhada da produção baseada nas lideranças, a implementação de uma política de manutenção estratégica e o investimento em sistemas informatizados também são fatores de suporte à sistemática proposta.

\subsection{A Concepção e o Desenvolvimento da Sistemática}

Para CAMPOS (1998), gerenciar é o ato de buscar as causas (meios) da impossibilidade de se atingir uma meta (fim), estabelecer contra medidas, montar um plano de ação, atuar e padronizar em caso de sucesso. Métodos ou sistemáticas são ferramentas concebidas para a prática desse gerenciamento. 
MÉTODO é uma palavra de origem grega resultante da soma das palavras META (“além de”) e HODOS (“caminho"). Portanto, método significa "caminho para se chegar a um fim".

"Desde que o homem começou a tomar consciência do mundo exterior e a interrogar-se a respeito dos fatos da natureza, foi movido por um impulso de "querer saber". Esse desejo de conhecimentos levava, necessariamente, à vontade de "saber fazer", isto é, de descobrir os caminhos que pudessem conduzi-lo ao seu objetivo. Surgiu assim a necessidade do "método"." (ANDRADE, 1999:20)

A fim de gerenciar as paradas planejadas em processos de produção de celulose e papel, será desenvolvida uma "sistemática", ou método, cuja função é organizar e controlar os meios para se exercer essa gestão.

\subsubsection{O modelo}

Na busca pelo estabelecimento de um "caminho" para atingir o sucesso no gerenciamento das paradas planejadas em processos de fabricação de celulose e papel, será desenvolvida uma sistemática a partir de uma visão desse evento sob o enfoque da manutenção.

Como sustentação para o detalhamento das atividades e etapas, serão utilizadas as abordagens revisadas no capítulo 4, as considerações da análise comparativa, bem como a experiência acumulada nos eventos de PG, com uma atenção especial para a PG2001 realizada na VCP_LA.

A figura 5.2 mostra de forma global a sistemática proposta, que é cíclica e subdividida em quatro etapas principais interdependentes.

A sistemática é baseada na caracterização dos eventos de parada planejada como grandes “empreendimentos". STONNER (2001), por exemplo, considera as paradas planejadas em uma unidade de processo como um empreendimento de grande porte, os quais na sua visão tem um ciclo de vida definido em quatro etapas básicas: concepção, planejamento, implementação e finalização. 


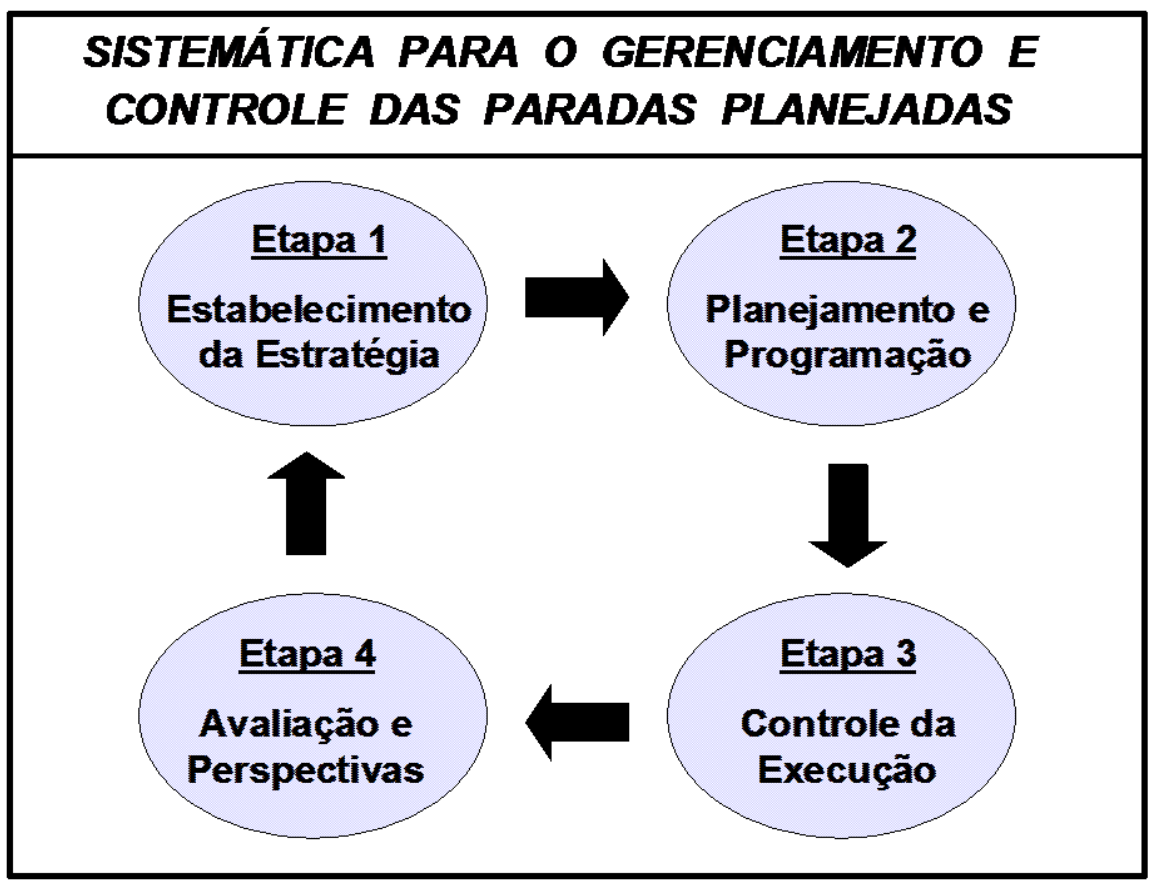

Figura 5.2 - Modelo da sistemática proposta.

De forma similar, a sistemática de gerenciamento proposta neste trabalho é dividida em quatro etapas que estabelecem uma atuação permanente sobre esses eventos, os quais passam a ser encarados como parte da estratégia que compõe a política de manutenção adotada para a planta fabril.

Dessa forma, tem-se uma estrutura interdependente que pressupõe muito planejamento, ações efetivas, comprometimento de todos os profissionais diretamente envolvidos e da alta direção da empresa, disciplina no cumprimento de todos os aspectos observados em cada uma delas e na aplicação das ferramentas adequadas para atividades específicas.

\subsection{O Detalhamento das Etapas da Sistemática}

Visando alcançar metas de mercado e promover otimizações na capacidade produtiva, a alta direção da empresa em conjunto com as gerências locais devem estabelecer as diretrizes, metas e desafios para o próximo evento, sendo a transparência um fator preponderante. Além disso, na Etapa 1 são relembradas as principais necessidades apontadas no final do último evento realizado e divulgado o 
cronograma master, cujo prazo é pré-definido pelo caminho crítico inicialmente identificado.

Com as diretrizes macros devidamente estabelecidas e acordadas, iniciase a Etapa 2, certamente a mais importante para o sucesso na realização da Parada. Todos os aspectos são tratados nesse momento, onde a sinergia entre os envolvidos, a realização de reuniões gerenciais e específicas (de forma periódica), a utilização de softwares especializados, a obtenção dos recursos necessários e uma aproximação direcionada com as prestadoras de serviços contratadas são fatores de destaque. A participação da equipe de manutenção nesta etapa é fundamental, centralizando as informações, direcionando e orientando as equipes, nivelando os recursos, acompanhando a evolução dos trabalhos de planejamento e preparação das atividades, bem como gerenciando a Parada como um todo.

A Etapa 3 é caracterizada pela atuação direta na planta fabril e tem início com a verificação de todos os procedimentos de parada do processo, feita preferencialmente na iminência dessa, e com a emissão das OS's e pedidos de liberações dos equipamentos e sistemas para as intervenções, onde basicamente têmse: a realização das manobras e liberações formais de parada, o recebimento das prestadoras de serviços e dos recursos, a execução das atividades programadas, as reuniões gerenciais e específicas de acompanhamento, a alimentação dos sistemas informatizados, o registro dos fatos relevantes, o monitoramento das atividades contratadas e a verificação dos procedimentos de comissionamento e partida do processo produtivo. Por fim, são realizadas as manobras de partida e a performance do processamento acompanhada durante um período de estabilização.

Finalmente, fechando o ciclo dessa sistemática têm-se a Etapa 4, marcada pelas reuniões de avaliação de desempenho, levantamento dos pontos fortes e fracos observados, verificação do desempenho das prestadoras de serviços, emissão do relatório gerencial final e análise crítica da sistemática aplicada. As recomendações e o apontamento dos principais serviços e investimentos vislumbrados para a próxima parada formam o conjunto das primeiras informações para a etapa 1 .

Objetiva-se com essa sistemática evitar a realização de atividades desnecessárias, uniformizar os procedimentos e a linguagem, garantir o foco nas intervenções e inspeções, bem como proporcionar um efetivo acompanhamento do 
evento. Além disso, o estímulo à análise crítica e sistêmica da gestão aplicada promove seu caráter estratégico e aperfeiçoamento contínuo.

\subsubsection{Etapa 1 - Estabelecimento da estratégia}

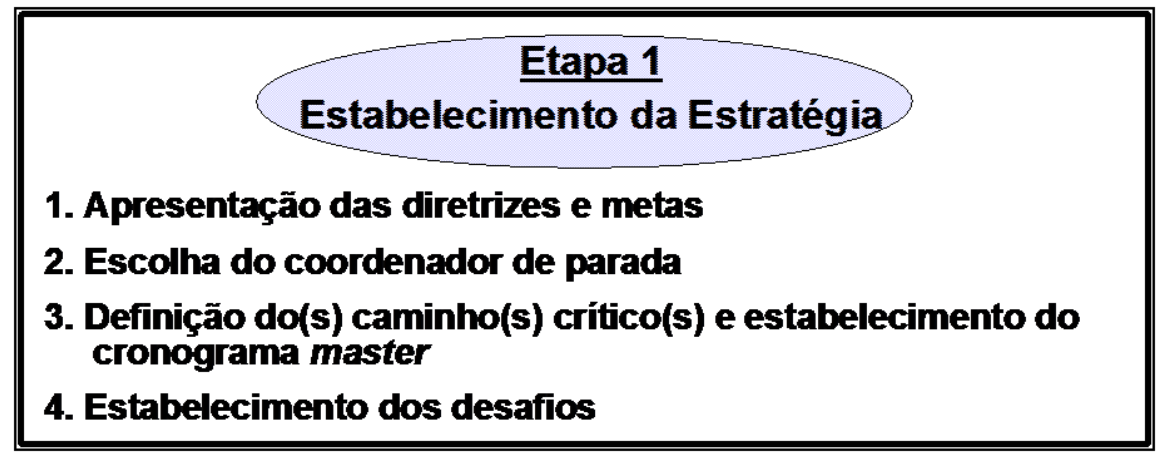

Figura 5.3 - Etapa 1: Estabelecimento da estratégia.

\section{Apresentação das diretrizes e metas}

Nas reuniões entre a diretoria da empresa, as gerências locais e a área central de planejamento de manutenção devem ser apresentadas as diretrizes macros para a parada (datas, prazos e custos).

A definição da data requer uma análise mais específica, sendo recomendável que se evite a realização desses eventos em paralelo com outras indústrias de grande porte do setor, devido a questões específicas como qualidade dos recursos necessários, prazos e disponibilidades. Como a mobilização é muito grande, eventos simultâneos podem competir entre sí, principalmente se estão na mesma região.

Também, o relatório final da parada anterior, os investimentos, principais serviços e atividades vislumbradas devem ser abordadas, visando estabelecer uma estratégia de atuação clara e completa.

\section{Escolha do coordenador de Parada}

Devido a quantidade de variáveis, atividades, pessoas e recursos envolvidos no evento, torna-se necessária a definição de um gestor global, que centralize todas as informações e coordene as equipes de planejamento, execução e controle de uma forma sistêmica. A esse gestor dá-se o nome de "coordenador de 
Parada", que torna-se responsável pelo andamento de todas as etapas do evento e gerenciamento de todos os aspectos que o envolvem.

\section{Definição do(s) caminho(s) crítico(s) e elaboração do cronograma master}

A análise dos principais serviços e ações a serem realizadas resulta na identificação da atividade também chamada de "carro-chefe" da PG, ou seja, é a intervenção mais demorada que define o período mínimo de indisponibilidade do processo produtivo. Por vezes, na observação de mais de um serviço crítico com durações similares ou interdependentes, ou que detenham um grau de complexidade que ofereça riscos potenciais aos prazos estabelecidos, recomenda-se tratativas de mesma intensidade e o destaque destes no cronograma master, o qual deve contemplar as atividades operacionais de parada e partida da planta fabril e o(s) caminho(s) crítico(s).

\section{Estabelecimento dos desafios}

Buscando uma atuação pró-ativa, as gerências das áreas produtivas devem estabelecer metas e desafios específicos, junto aos profissionais diretamente envolvidos com as atividades. Além disso, recomenda-se que as metas e desafios alcançados no evento anterior sejam cuidadosamente observados, através do relatório final da parada anterior (atividade 4 da etapa 4). Como exemplos, têm-se a otimização dos recursos, o desempenho das contratadas, a redução do tempo total da Parada, de serviços específicos, dos custos, de acidentes, de retrabalhos etc..

\subsubsection{Etapa 2 - Planejamento e programação}

\section{Detalhamento de todas as atividades e nivelamento dos recursos e prazos}

As áreas de Manutenção, de Operação e de Engenharia devem reunir-se para a definição de todas as atividades necessárias (limpezas operacionais, inspeções, testes, intervenções preventivas, intervenções corretivas em carteira, melhorias, modificações, entre outras), detalhamento dos recursos para execução de cada uma, verificação das interfaces, interdependências e de todos os valores envolvidos. Neste 
momento, normalmente ocorrem os ajustes quanto aos valores orçados, tempo total de indisponibilidade do processo e caminhos críticos, buscando-se um "ajuste fino" e a otimização dos recursos.

\section{Planejamento e Programação}

1. Detalhamento das atividades e nivelamento dos recursos

2. Identificação dos fatores de risco e as formas de controle

3. Programação das atividades e emissão dos cronogramas

4. Elaboração dos organogramas e distribuição das atividades

5. Reuniōes de planejamento centralizado

6. Reuniōes de multidisciplinares especificas

7. Reuniōes de gerenciamento global

8. Aquisição de sobressalentes, recursos e materiais

9. Contratação dos serviços e recursos de apoio

10. Reuniōes com as provedoras de recursos e serviços

11. Estabelecimento das equipes e procedimentos de parada $e$ partida da planta

12. Padronização de informativos durante o evento de parada

13. Preparativos finais para as intervençōes

14. Check-list do planejamento e programação

Figura 5.4 - Etapa 2: Planejamento e programação.

“... em épocas de grandes reparos, os supervisores de manutenção e operação reúnem-se a fim de esquematizar sua programação de forma a reduzir ao máximo o período de indisponibilidade do sistema operacional ..." (TAVARES, 1999: 126).

Além disso, recomenda-se uma avaliação prévia quanto aos fatores segurança e meio ambiente, sendo que estes devem prevalecer na definição do tempo total de indisponibilidade e nos custos envolvidos. Também nesta fase, torna-se indispensável a utilização de métodos como PERT, CPM e dos sistemas informatizados de apoio (item 3.4) para a promoção de uma maior assertividade no planejamento e nivelamento dos tempos e recursos envolvidos.

Para atividades críticas, recomenda-se a revisão desse levantamento nas reuniões multidisciplinares específicas, como será abordado à frente. 


\section{Identificação dos fatores de risco e definição das formas de controle}

Várias são as dificuldades e os desafios, tanto de caráter administrativo quanto técnico, a serem superados durante o planejamento e a realização de uma parada planejada. Face a isso, na etapa de planejamento a identificação clara dos "fatores de risco" e a definição de "formas de controle" para o monitoramento da evolução dos mesmos torna-se indispensável.

Nota-se que os fatores de risco são específicos para cada evento. Entretanto, existem alguns comuns e inerentes as grandes paradas:

- desvios dos custos orçados;

- atrasos na liberação e retorno dos equipamentos e instalações;

- excesso de atividades imprevistas;

- falta de recursos necessários no momento das intervenções;

- acidentes com pessoas, bens e meio ambiente etc..

Desta forma, deve-se observar que esses fatores, se não acompanhados e controlados de forma sistemática, podem comprometer todo o evento de parada. Neste sentido, devem ser desenvolvidas algumas formas para seu monitoramento, que torne possível uma gestão mais específica e efetiva desses riscos, como os exemplos abaixo:

- formar um grupo de pessoas para a centralização de todas as informações relativas ao evento;

- divulgar de forma clara os valores, prazos, metas e estratégicas;

- emitir o cronograma master com a antecedência adequada, contemplando os todos os caminhos críticos;

- criar mecanismos para o acompanhamento da evolução de todas as variáveis envolvidas, como: custos, acidentes, retrabalhos, atrasos, processos de compras, contratação de serviços, recursos de apoio etc..;

- fazer check-lists para os preparativos específicos de pré Parada;

- revisar os procedimentos de parada e partida operacionais;

- analisar e registrar a realização de atividades imprevistas;

- acompanhar a evolução de todos os trabalhos em execução;

- monitorar as horas extras realizadas; 
- acompanhar o desempenho das prestadoras de serviços, entre outros.

Assim, esses são alguns dos parâmetros que podem ser utilizados para o gerenciamento dos fatores que requerem uma atenção diferenciada.

A idéia é, a partir da identificação dos riscos, definir formas de agir para gerenciá-los à fim de que cada um deles sejam eliminados ou minimizados. Normalmente, têm-se como ferramentas de suporte as FTA, FMEA e RCFA.

\section{Programação das atividades e emissão dos cronogramas}

Nesta fase, todas as atividades a serem realizadas durante o evento, sejam elas de manutenção, limpeza, inspeção ou de qualquer outra origem devem ser contempladas nos cronogramas detalhados emitidos pela área de planejamento de manutenção. Os planejadores devem reavaliar as atividades e programá-las nos sistemas informatizados de apoio (registrando as OS's) a fim de que os recursos necessários para sua realização sejam disponibilizados e o momento de sua execução definido e alocado oficialmente nos cronogramas.

Assim, recomenda-se a verificação de todas as necessidades para:

- a emissão de requisições para compra dos recursos humanos e serviços necessários, junto a área comercial (compras e suprimentos);

- planejamento das atividades no sistema através de OS's, com a alocação dos recursos (sobressalentes, ferramentas e materiais);

- os ajustes necessários nos cronogramas junto as equipes de planejamento de manutenção e operação das áreas (sub-processos);

- a emissão dos cronogramas detalhados para cada atividade e das interfaces entre atividades interdependentes;

- a definição do organograma para o evento, constituído das equipes e suas respectivas atribuições e áreas de atuação etc.

Dessa forma, os planejadores de manutenção são os elementos de ligação entre todas as pessoas, áreas, especialidades e aspectos que circundam o evento. Também nesta fase, o suporte de softwares (MS Project, por exemplo) é indispensável. 


\section{Elaboração dos organogramas e distribuição das atividades}

As atribuições e as responsabilidades de todos durante a PG devem ser claras e divulgadas com antecedência, preferencialmente na forma de organogramas.

Além disso, todas as variáveis (custos, prazos etc.) e atividades (limpezas, inspeções, intervenções, apoio etc.) devem ter responsáveis que as gerenciem completamente, desde a sua compra até a utilização.

Para intervenções críticas e complexas, devem ser formados grupos multidisciplinares para as análises necessárias (recursos, prazos, ARP, entre outras), bem como para sua execução e acompanhamento da evolução. A aplicação de técnicas da qualidade (como $5 S$, Kaizen e TPM) podem contribuir para o aperfeiçoamento das ações e análises em grupos.

\section{Reuniões de planejamento centralizado}

Tendo o cronograma master e os específicos (para áreas, recursos e atividades), os planejadores de manutenção das áreas junto aos especialistas e representantes das equipes operacionais devem se reunir para o detalhamento e a verificação das interfaces entre atividades operacionais (limpezas, procedimentos de parada e partida etc.), inspeções e intervenções. Os principais objetivos são a otimização dos recursos e dos tempos envolvidos, bem como a identificação de riscos potenciais e pontos de atenção, com a formulação de planos de contingências.

As interfaces que evolvem o(s) caminho(s) crítico(s) são os principais focos de preocupação nessas reuniões, que devem ser realizadas após o detalhamento de todas as atividades, definição dos parâmetros de controle e distribuição das responsabilidades, promovendo a revisão de todos os programas específicos emitidos. A participação de representantes das áreas de apoio e do coordenador de Parada são fundamentais, sendo que a quantidade de encontros necessários depende do atendimento das metas e do surgimento de novas atividades e intervenções.

Softwares especialistas e de gerenciamento, planejamento e controle, já observados no capitulo 3, são indispensáveis neste momento, além da utilização de métodos como PERT e CPM. 


\section{Reuniões multidisciplinares específicas}

Atividades e intervenções mais complexas e críticas, como controlar os pedidos de compra e os custos, realizar as limpezas operacionais e inspeções, fazer manutenções planejadas e modificações em equipamentos e instalações de difícil acesso e de grande porte, trazem a necessidade de análises mais específicas, a fim de se planejar, executar, acompanhar e controlar a atividade de uma forma completa e com cuidados especiais (segurança e meio ambiente, por exemplo). Normalmente, os caminhos críticos e as formas de controle, definidas a partir dos fatores de risco observados para o evento, requerem esse tipo de tratativa diferenciada.

A formação de grupos de trabalho e as reuniões periódicas são indispensáveis para um gerenciamento adequado dessas atividades, que podem envolver várias especialidades, disciplinas, funções e níveis hierárquicos. Devem ter a participação de todos os envolvidos e principalmente dos executantes, sendo recomendável uma periodicidade mais freqüente quanto mais próxima a Parada.

Cronogramas específicos para essas reuniões devem ser estabelecidos juntamente às equipes de trabalho e divulgados pela área de planejamento de manutenção. As principais ferramentas utilizadas nesses encontros são as APP, as ARP e os Ciclos PDCA e SDCA, bem como atividades de capacitação e treinamentos devem ocorrer se necessário.

\section{Reuniões de gerenciamento global}

As paradas planejadas nas indústrias papeleiras envolvem vários processos e sistemas interligados e interdependentes e, além disso, inúmeras áreas e recursos de apoio. Tudo deve estar claro e todos têm de ter uma visão global do evento, para saber onde buscar apoio e recursos, bem como conhecer a estratégia de mercado adotada e a importância de sua(s) atividade(s) nesse contexto.

Buscando essa visão e comprometimento, devem ser realizadas reuniões de cunho gerencial com as pessoas chaves, chefes de setores, representantes dos grupos de trabalho, gerentes locais e diretores corporativos, nas quais sejam discutidas questões como o andamento de todos os preparativos, a evolução dos custos, as aquisições representativas e que requeiram uma atenção diferenciada quanto ao prazo de entrega, a contratação de serviços, os aspectos de segurança e os 
padrões de trabalho desejados nas áreas.

Também, para esses encontros recomenda-se uma periodicidade com frequiência progressiva e divulgação ampla. O cronograma master, os organogramas, as interferências entre as atividades em linhas e equipamentos inter-relacionados dos subprocessos (interfaces), a rede de suprimentos e os planos de contingências para os riscos potenciais são algumas formas para direcionar e conduzir essas discussões, gerenciadas pelo coordenador de Parada.

\section{Aquisição de sobressalentes, recursos e materiais de consumo}

Os processos para a aquisição das ferramentas especiais, equipamentos de apoio (iluminações, máquinas de corte e solda, sistemas de alinhamento etc.), materiais de consumo (eletrodos de solda, vedantes, discos de corte e desbaste etc.) e demais recursos e equipamentos necessários devem ser acompanhados e monitorados continuamente junto as áreas de compras e suprimentos. Para isso, a participação de representantes destas áreas nas diversas reuniões já abordadas, durante todas as etapas de gerenciamento do evento é de fundamental importância para o perfeito alinhamento das necessidades com as metas estabelecidas (prazos, custos e padrões de qualidade).

Com isso, as equipes de trabalho, os planejadores de manutenção e o coordenador de parada, a partir de necessidades específicas identificadas, têm o papel de envolver essas pessoas para fazer da rede de suprimentos um ponto de suporte para o sucesso na realização das intervenções. A identificação das necessidades com antecedência são as premissas básicas para evitar ou minimizar problemas e atrasos provenientes das aquisições e locações, bem como a delegação de profissionais das áreas produtivas para a gestão dessas e suporte técnico aos compradores.

Os sistemas informatizados de gerenciamento integrado tornam estas atividades menos complexas e mais ágeis, bem como a prática de uma política de parceria com os diversos fornecedores facilita a aquisição dos recursos e garante a qualidade dos mesmos. Check-lists para a verificação do estado dos materiais adquiridos e locados devem ser desenvolvidos e padronizados de acordo com o grau de qualidade exigido e estabelecido contratualmente. 


\section{Contratação dos serviços e recursos de apoio}

Os mesmos cuidados observados na aquisição dos recursos materiais devem ser tomados para a contratação dos recursos de mão-de-obra, assistências e serviços de apoio.

Os principais tipos de serviços e recursos contratados são:

- Manutenções contratuais e assistências técnicas - devido as caraterísticas específicas desses serviços, quanto a tecnologia utilizada e especialização necessária, as empresas fornecedoras normalmente são parceiras de grande porte e fabricantes dos equipamentos (responsáveis pelo fornecimento, assistência técnica e manutenções periódicas). Normalmente, são multinacionais e acompanham as tendências e necessidades do mercado globalizado, tendo-se valores previamente estabelecidos em contrato, bem como uma qualidade assegurada do serviço realizado, além de um maior comprometimento. $O$ papel da contratante normalmente é de simples acompanhamento e suporte;

- Contratação de mão-de-obra por administração e preço unitário - a grande maioria dos serviços realizados durante uma parada planejada envolvem atividades padrão, que demandam muito mais horas homens e materiais de consumo que sobressalentes específicos e novas instalações. Como exemplo, têm-se as desmontagens e montagens de bombas, válvulas, linhas e estruturas de suporte, a abertura de acessos e manobras para inspeções e limpezas, os pequenos reparos em tubulações ou estruturas (aplicações de solda e vedantes em geral), as substituições de equipamentos etc. Para esse tipo de atividade recomenda-se a contratação de mão-de-obra por homens hora, nesse caso chamada de contratação por "administração", e por metragem ou execução, conhecida por "preço unitário". O importante nesse tipo de contratação é a idoneidade da contratada, bem como a qualidade da mão de obra fornecida, haja vista que todas as responsabilidades são da contratante;

- Contratação de mão-de-obra por pacotes - em outros casos, têm-se equipamentos de grande porte que demandam tecnologias específicas para os reparos (equipamentos constituídos por vasos de pressão, estruturas complexas e de tecnologia diferenciada). Para esse tipo de serviço existem empresas especializadas, e o serviço pode ser contratado como um todo em forma de 
“pacotes", onde o tempo de duração da intervenção é discutido e trabalhado junto à contratada, de forma a não impactar negativamente nas indisponibilidades previamente definidas. O acompanhamento da contratante é fundamental devido à importância estratégica da intervenção, porém todas as responsabilidades são assumidas pela contratada, sendo esta penalizada em caso de atrasos;

- Contratação de recursos de apoio - são os recursos que garantem toda a infraestrutura básica necessária para a realização do evento, como montagens e desmontagens de andaimes e isolamentos térmicos, guinchos, guindastes, empilhadeiras, caçambas, containers sanitários etc. Um trabalho de logística bem estruturado deve ser desenvolvido em conjunto com os provedores desses recursos, bem como os contratos firmados levar em conta os padrões de qualidade exigidos e as verificações técnicas realizadas no recebimento dos mesmos.

\section{Reuniões com as prestadoras de serviços e provedoras de recursos}

Após a definição das empresas contratadas, o coordenador de Parada deve, juntamente as áreas de apoio, promover reuniões específicas para o alinhamento dos padrões estabelecidos, principalmente quanto a segurança, responsabilidades contratuais, níveis de decisões, utilização de recursos comuns, logísticas, fluxo de informações, acompanhamento de desempenhos etc. A relação de transparência e confiança entre contratante e contratada é primordial, bem como o envolvimento da última para com as metas, desafios estabelecidos e aspectos ligados a fatores estratégicos como meio ambiente e segurança, segundo observa PINTO\&XAVIER (1999:180):

"Esta é uma questão [a segurança] fundamental e não dá para tratar de empresa excelente, parceria e competitividade se não for encarada de forma estratégica. Os mesmos programas e resultados buscados e praticados pela Contratante devem ser buscados pela Contratada. É preciso unificar a maneira de ver as pessoas, resultados e abrangências dos programas de segurança..."

Face a isto, as áreas de recursos humanos, comercial e segurança devem estar diretamente envolvidas nessas reuniões, devido as variáveis legais e burocráticas envolvidas. A não participação de representantes das contratadas nesses encontros pode resultar em sua desqualificação para o evento, sendo que este fator deve ser monitorado sem complacência pela contratante. 


\section{Estabelecimento de equipes multifuncionais e procedimentos para parada e partida da planta}

Toda estratégia e planejamento serão em vão e a execução da Parada comprometida se no momento da entrega dos sistemas e equipamentos os procedimentos adequados não forem aplicados corretamente.

É importante lembrar que todos os cronogramas são interrelacionados, pois os sub-processos são interdependentes. As "reduções e paradas" dos equipamentos e sistemas são fundamentais para as liberações necessárias às intervenções programadas, muitas vezes dependentes de resfriamentos, medições de gases e temperaturas, liberações de segurança etc.

Diante desses fatores, é importante que procedimentos padrões detalhados sejam estabelecidos pelas equipes de operação e manutenção, sob um enfoque multiespecialista e multifuncional, com a finalidade de evitar desvios neste momento, e com isso atrasos significativos no início dos trabalhos.

Para o "retorno", os cuidados devem de ser ainda maiores, haja vista o desgaste de todos os envolvidos, resultado de vários dias de trabalho em regime de doze horas, bem como a importância de se executar um retorno perfeito para o sucesso de todo o evento. Para isso, também são necessários procedimentos claros e check-lists detalhados.

Deve-se ainda observar que, após as intervenções nos equipamentos e sistemas, são realizados comissionamentos e testes nos mesmos, os quais devem ser revistos e adequados se necessário. A quantidade de parâmetros tornam necessária um equipe bem treinada e capacitada, de preferência coordenada por um profissional de instrumentação ligado diretamente ao coordenador de parada.

Finalmente, deve-se notar que as atividades de parada e partida do processo produtivo fazem parte da etapa de execução do evento (etapa 3), sendo que seu sucesso ou fracasso causa impactos representativos no seu resultado global.

\section{Padronização de informativos durante o evento de Parada}

Na realização de um evento que reúne centenas de pessoas e dezenas de empresas torna-se necessária a promoção de um fluxo de informações confiáveis e convenientes, com a finalidade de evitar transtornos provenientes de boatos sobre 
acidentes e falhas, e mantendo sempre a motivação das pessoas e a transparência na gestão. Os sistemas informatizados de informações, como visto no capítulo 3, têm a função de manter uma forte rede de informações internas, porém demandam tempo e disponibilidade de recursos para seu perfeito aproveitamento, além de serem pouco eficazes diante momentos em que a maioria dos profissionais atuantes são de empresas contratadas e, normalmente, não têm acesso a esses sistemas.

Outras formas de comunicação também devem ser utilizadas como: painéis informativos, cartazes, faixas, folhetos, folders etc. Estes, devem estar localizados estrategicamente, ser atualizados continuamente pelos planejadores de manutenção e auditados sistematicamente pelo coordenador de Parada.

\section{Preparativos finais para as intervenções}

Para que todas as atividades e intervenções ocorram conforme planejado, é essencial que as providências e preparativos de pré-parada sejam vislumbrados e realizados com atenção e cuidados especiais. Os planos traçados através das ARP, Ciclos PDCA e SCDA para os serviços complexos e críticos devem ser executados com disciplina, bem como as verificações e checks aplicados efetivamente.

Alguns trabalhos devem ser preparados com dias ou até semanas de antecedência, face a sua complexidade ou possibilidade de ganho quanto ao tempo total de indisponibilidade do processo. Como exemplos, têm-se:

- a realização de integrações e treinamentos específicos;

- a disponibilização dos recursos e equipamentos a serem utilizados nos locais próximos as intervenções;

- a reunião dos profissionais das empresas contratadas para reconhecimento do ambiente de trabalho e serviços específicos;

- atividades de preparação que envolvem a substituição de grandes equipamentos e estruturas, e que possam ser montadas com antecedência;

- desmontagem de isolamentos térmicos;

- montagem de andaimes e plataformas de trabalho;

- atividades de construção civil para novos equipamentos etc. 
Contudo, recomenda-se a execução de toda e qualquer atividade que possa ser realizada com antecedência, já que isto proporcionará uma redução na quantidade de trabalhos que constituem a parada planejada e consequentemente em seu prazo ou, ao menos, descongestionará o momento do evento. Os maiores ganhos na otimização do tempo total de indisponibilidade do processo produtivo está numa avaliação criteriosa destas possibilidades.

\section{Check-list do planejamento e programação}

Ao final desta etapa, recomenda-se uma verificação quanto a todos os tópicos tratados, ou seja, faz-se a checagem do planejamento do evento e todos os programas e cronogramas são revisados. A idéia é partir para a execução da Parada com todos as formas de controle, providências e preparativos ajustados e confirmados de acordo com as diretrizes, metas e desafios estabelecidos.

O responsável por esta verificação é o coordenador de parada, devendo ser realizada ao final da etapa 2. Na constatação de irregularidades ou falhas, deve-se avaliar seus impactos para a confirmação ou não do início do evento.

\subsubsection{Etapa 3 - Controle da execução}

\section{Check-list dos procedimentos de parada da planta}

Para a garantia de sucesso e cumprimento dos prazos para resfriamentos, descompressões, descontaminações e liberações dos equipamentos e instalações, é importante a verificação e revisão dos procedimentos e passos a serem seguidos, promovendo o comprometimento e a sinergia entre os profissionais que atuam diretamente nestes momentos: técnicos de segurança e meio ambiente, bombeiros, operadores (de área e SDCD), eletricistas, instrumentistas, mecânicos etc.

É importante lembrar que os procedimentos padrão detalhados foram estabelecidos pelas equipes de operação e manutenção na etapa 2 (atividade 11) e, dessa forma, devem apenas serem validados e confirmados antes do início das ações. 


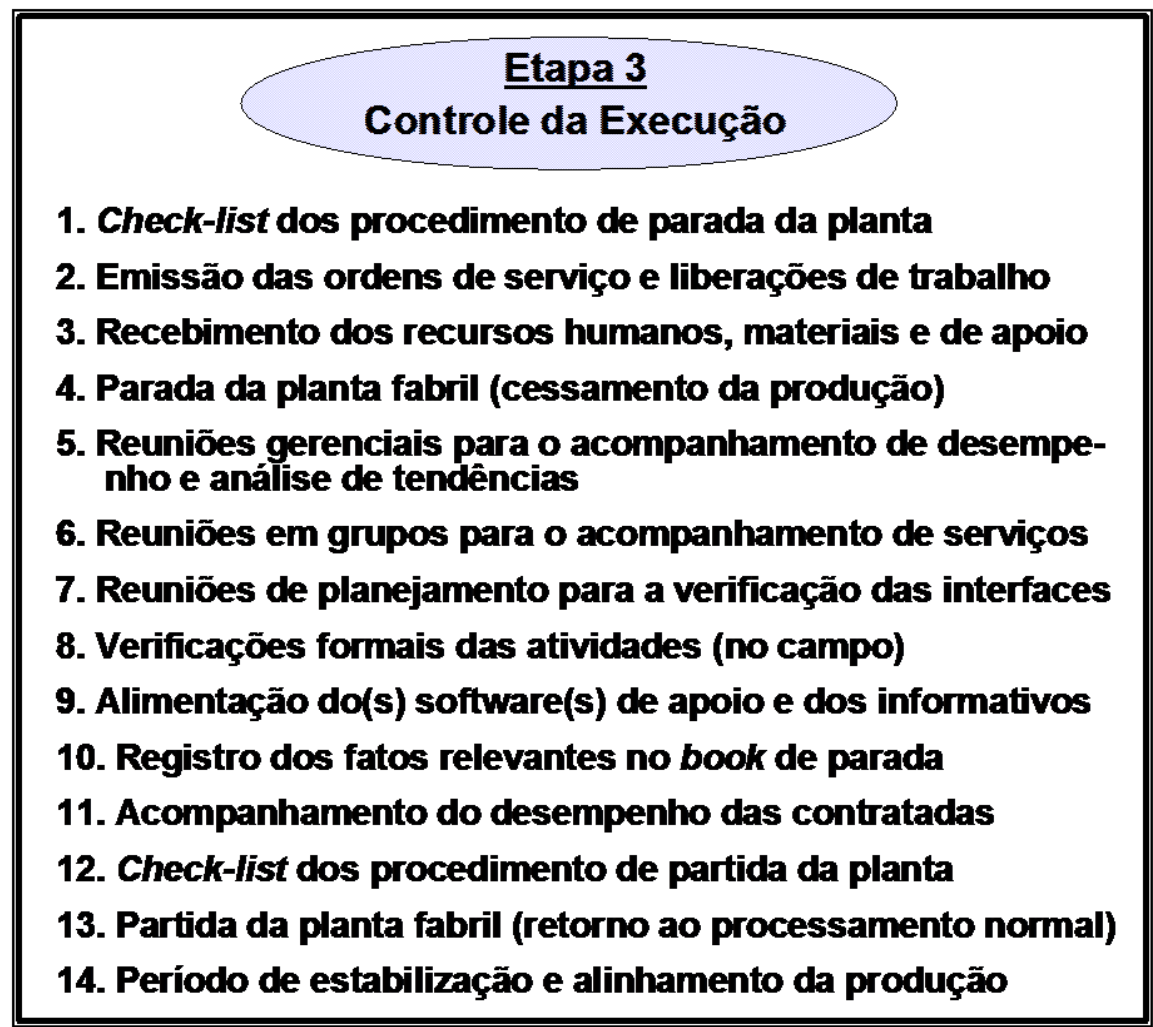

Figura 5.5 - Etapa 3: Controle da execução.

2. Emissão das ordens de serviço e liberações de trabalho

No início da etapa 2 (atividade 3), todas as atividades e intervenções foram colocadas nos sistemas informatizados através de OS, com os recursos necessários alocados e anexadas as recomendações de segurança e os procedimentos de liberação. Para as intervenções propriamente ditas, as OS's devem ser liberadas e entregues aos executantes ou responsáveis, preferencialmente "da casa" (devido a questões legais e estratégicas).

Nenhum trabalho pode ser liberado, executado ou finalizado sem esse documento, o qual tem seu número relacionado com as proteções e procedimentos de segurança, como por exemplo os "cartões de bloqueio". A presença de técnicos de segurança, operação, manutenção e o acompanhamento de bombeiros (em casos específicos) é obrigatória.

A emissão dessas OS's são de responsabilidade dos planejadores de manutenção, e deve ocorrer dias antes da parada da planta. Entretanto, para algumas atividades críticas, podem ser emitidas após o cessamento da produção.

Aqui, a utilização de softwares agiliza e facilita o trabalho dos 
planejadores de manutenção, bem como garante um histórico confiável.

\section{Recebimento dos recursos humanos, materiais e de apoio}

No recebimento dos recursos materiais e de apoio, recomenda-se a verificação de "todos" no momento de sua chegada, a fim de certificá-los quanto a qualidade e cumprimento dos requisitos e padrões praticados pela contratante e acordados em contrato. Para isso, são formadas equipes multidisciplinares, normalmente compostas por profissionais de manutenção (eletricistas, instrumentistas e mecânicos), da área de recebimento e da segurança, que trabalham em conjunto fazendo um check padrão previamente definido. No caso de anormalidades, o fornecedor deve ser informado e a correção solicitada.

Quanto aos recursos humanos, devido a questões legais e de segurança, tem-se uma estrutura mais complexa, onde se faz necessária a verificação de todas as documentações e qualificações requeridas, bem como a realização das chamadas "Integrações" (onde são transferidas informações gerais, procedimentos e normas de segurança da empresa, particularidades do ambiente de trabalho e padrão de comportamento esperado).

As áreas de treinamento, desenvolvimento e segurança normalmente são as responsáveis por esses eventos, que devem ser promovidos diante um planejamento adequado a quantidade de empresas envolvidas, pois nenhum profissional contratado deve ser autorizado a atuar nas áreas fabris sem a participação nas mesmas. Para evitar problemas e facilitar o controle dessa questão, um certificado entregue ao final das Integrações e anexado aos crachás, por exemplo, pode ser implementado.

No caso de serviços em equipamentos ou ambientes específicos, recomenda-se a reunião dos envolvidos para palestras ou discussões direcionadas aos cuidados adicionais necessários, junto aos especialistas da área em questão.

\section{Parada da planta (paralisação da produção)}

Desde a redução do volume de produção até o cessamento da mesma, várias são as manobras operacionais e procedimentos necessários, numa planta de fabricação de celulose e papel. Esses, devem ser realizados pelas equipes de parada 
de acordo com os procedimentos estabelecidos na etapa 2 (atividade 11) e checados na etapa 3 (atividade 1).

Todos os passos devem ser realizados nos momentos estabelecidos pelas programações emitidas, a fim de evitar atrasos nas liberações dos postos de trabalho e garantir a segurança durante as reduções. Os desvios devem ser informados com presteza e clareza, para que ações contingentes possam ser tomadas sem maiores prejuízos aos planos preestabelecidos.

A evolução das manobras, dos parâmetros de redução e dos procedimentos de liberação dos equipamentos e instalações devem ser acompanhados e monitorados pelo coordenador de parada em conjunto com a equipe de parada e partida da planta fabril.

Cada liberação deve ser certificada e informada, bem como o início dos trabalhos em questão, se necessário, com acompanhamento.

\section{Reuniões gerenciais para o acompanhamento de desempenho e análise das tendências}

Durante o evento, devem ser realizadas reuniões para a avaliação do andamento de todos os trabalhos críticos, o confronto das metas e desafios (real versus planejado - prazos, custos e parâmetros de controle), as tendências, os desvios relevantes e a evolução dos indicadores de segurança e meio ambiente. Como participantes indispensáveis, têm-se as pessoas chaves, chefes de setores, representantes dos grupos de trabalho e das contratadas, gerentes locais e diretores corporativos.

Recomenda-se que esses encontros ocorram no mínimo uma vez ao dia, tenham uma divulgação ampla e sejam registrados em "atas". A verificação e atualização do cronograma master, a confirmação dos recebimentos e prazos da rede de suprimentos e a observação de riscos potenciais são alguns aspectos também abordados pelo coordenador de parada nessas reuniões.

\section{Reuniões em grupos multidisciplinares para o acompanhamento de serviços específicos, críticos e imprevistos}

Com já foi visto na etapa 2 (atividade 4), para as atividades e interven- 
ções mais complexas e críticas devem ser definidos grupos multidisciplinares, responsáveis na etapa 3 pelo acompanhamento e monitoramento pontual e específico desses trabalhos. Assim, esses grupos devem realizar reuniões periódicas para um gerenciamento efetivo da evolução da atividade, registrando e analisando os desvios e tomando as ações contingentes necessárias, as quais devem ser devidamente informadas nas reuniões gerenciais.

Como na etapa de planejamento, devem ser estabelecidos e divulgados cronogramas específicos para esses encontros e, diante as necessidades, deve-se envolver o coordenador de parada.

As principais ferramentas utilizadas nesses encontros são: os programas estabelecidos para as atividades; as FTA; FMEA; RCFA e os Ciclos PDCA; principalmente na ocorrência de falhas e desvios.

Já na observação de atividades imprevistas, resultantes de inspeções e oportunidades identificadas com o andamento da parada do processo, grupos devem ser formados para sua análise quanto a real necessidade e viabilidade. $O$ envolvimento de especialistas, planejadores e do coordenador de parada é indispensável, e os procedimentos de execução e acompanhamento adotados, bem como as ferramentas utilizadas nas atividades e intervenções complexas e críticas.

\section{Reuniões de planejamento para a verificação das interfaces}

Após o detalhamento dos serviços e a verificação das interfaces e interdependências realizados na etapa 2 (respectivamente atividades 1 e 2), faz-se necessária a revisão de todos os programas com o andamento dos trabalhos durante a Parada. Os desvios devem ser analisados e ações contingentes acordadas entre as áreas, com a supervisão do coordenador de parada.

A periodicidade desses encontros deve ser definida entre as áreas, de acordo com as necessidades, atendimento das metas estabelecidas, surgimento de novas atividades e oportunidades de ganho. Todas essas definições devem ser informadas e revistas nas reuniões gerenciais.

Também nesses momentos, são indispensáveis softwares especialistas e de gerenciamento, planejamento e controle para a rapidez nas atualizações, bem como a utilização de métodos como PERT-CPM, se necessário. 


\section{Verificações formais das atividades em desenvolvimento (no campo)}

Durante a execução das atividades, recomenda-se a verificação de sua evolução "in loco", a partir de check-lists (previsto versus realizado), apontamentos em planilhas específicas (desvios, durações e anormalidades), gráficos de performance e registros padronizados (fotos, relatórios, análises e tendências). Essas verificações são necessárias em virtude da alimentação dos sistemas informatizados, reuniões gerenciais, específicas e de planejamento, sendo que a veracidade e confiabilidade das informações têm de ser total.

Normalmente, as verificações são realizadas periodicamente a partir de um plano preestabelecido, por profissionais da casa e com a supervisão do coordenador de parada. Dependendo da atividade ou intervenção observada, as verificações podem ser feitas de forma detalhada, global ou por amostragem.

Para os serviços realizados por empresas contratadas, as tratativas devem ser as mesmas, e os dados colhidos levados aos grupos responsáveis.

\section{Alimentação do(s) software(s) de apoio e atualização dos informativos}

Os técnicos e planejadores de manutenção devem ser os principais responsáveis pela alimentação dos sistemas informatizados, garantindo os históricos da Parada e os dados e informações para as avaliações de performance e desvios nas reuniões gerenciais e de planejamento. O fechamento das OS's, a atualização dos tempos reais nos cronogramas, os dados colhidos nas verificações formais das atividades no campo e o registro dos desvios são alguns detalhes que devem ser transferidos e atualizados continuamente. Da mesma forma, os painéis informativos, cartazes, faixas e folhetos devem ser atualizados continuamente durante a parada pelos planejadores de manutenção, bem como auditados sistematicamente pelo coordenador de Parada.

\section{Registro dos fatos relevantes no Book da Parada}

Além da alimentação dos softwares e da atualização dos informativos gerais, recomenda-se o registro de todos os pontos e fatos relevantes observados durante o evento num livro único ("Book da Parada"). As atividades extras realizadas, os pontos fracos e fortes, as otimizações obtidas, os principais desvios e 
interferências, bem como as novas oportunidades identificadas são algumas das informações essenciais neste livro, que deve ser o principal histórico da parada e cuja e atualização sistemática é de responsabilidade do coordenador de parada. Os relatórios de performance do planejamento e desafios alcançados também devem ser anexados ao final do evento.

Este livro será utilizado e verificado nas atividades da etapa 4, e em virtude disso deve ser elaborado de forma clara e transparente. Também pode ser utilizado para observações referentes a sistemática de gerenciamento do evento aplicada, tendo a visão voltada ao aperfeiçoamento contínuo.

\section{Sistema de acompanhamento do desempenho das contratadas}

No momento da contratação de serviços, mão-de-obra e recursos de apoio, várias diretrizes, metas, penalizações e normas são acordadas e relacionadas em contrato, como abordado na etapa 2 (atividade 9). Ainda nesta etapa, nas reuniões realizadas com estas empresas deve ficar claro que além do cumprimento das cláusulas contratuais, seu desempenho será avaliado, tanto de forma global quanto por profissional, em casos específicos (soldadores de vasos de pressão, por exemplo).

A obtenção dos dados dá-se nas verificações formais periódicas das atividades e serviços em execução, já abordadas nesta etapa 3 (atividade 8). Como principais objetivos desse acompanhamento, têm-se o monitoramento da evolução dos serviços contratados face as metas e desafios estabelecidos, através de gráficos de performance e registros padronizados (fotos, relatórios, análises e tendências).

$\mathrm{Na}$ ocorrência de falhas ou desvios, reuniões devem ser imediatamente promovidas para a definição das ações e correções necessárias, junto aos representantes das contratadas e profissionais envolvidos na atividade. Esses apontamentos e relatórios devem ser anexados ao Book da Parada ao encerramento da etapa 3, e serão utilizados na etapa 4 para a avaliação final, recomendações, e histórico.

\section{Check-list dos procedimentos de partida da planta fabril}

Como na iminência da parada da planta (atividade 1 desta etapa), a verificação das manobras e procedimentos para a partida se faz essencial a fim de garantir o perfeito retorno dos equipamentos e sistemas ao final da etapa 3 , na 
iminência do retorno do processo. Para isso, devem ser utilizados procedimentos claros, check-lists detalhados e planos de contingências apropriados.

As verificações, revisões e atualizações desses procedimentos e passos (manobras, comissionamentos e testes) a serem seguidos devem ser tratados pela equipe de partida, já formada na etapa 2 (atividade 11), sob coordenação de um profissional de instrumentação, ligado diretamente ao coordenador de parada.

É sempre interessante lembrar que, neste momento, os cuidados devem de ser ainda maiores, devido ao desgaste de todos os envolvidos e a importância de se promover um retorno perfeito para o sucesso de todo o evento.

Por fim, a verificação do termino de todas as atividades executadas e a inspeção dos equipamentos e sistemas que sofreram intervenções também devem ser realizadas para o início do retorno do processo produtivo.

\section{Partida da planta (retomada do processamento normal)}

Recomenda-se que todas as manobras operacionais e procedimentos para o retorno da planta a operação normal sejam realizadas por uma equipe específica e de acordo com o estabelecido pela sistemática na etapa 2 (atividade 11).

Nesse momento, ao final da etapa 3, tudo deve ser checado, bem como os comissionamentos e testes realizados nos equipamentos e sistemas que sofreram intervenções.

Também nessa fase, os planos e programações devem ser seguidos à risca, evitando atrasos e garantindo a segurança durante o retorno. As falhas e desvios devem ser informados e analisados rapidamente, para que ações contingentes sejam tomadas sem maiores prejuízos aos prazos e desafios estabelecidos.

A evolução das manobras, procedimentos e parâmetros de partida devem ser acompanhados e monitorados continuamente pela equipe de partida, juntamente ao coordenador de parada.

\section{Período de estabilização e alinhamento da produção}

Nas plantas de processamento contínuo, após grandes paradas de produção, a estabilização do processo como um todo não é imediata, e leva algum tempo. Nas indústrias de fabricação de celulose e papel, esse período é de 
aproximadamente 24 horas, e requer alguns cuidados específicos e um acompanhamento detalhado e efetivo.

Parâmetros de operação devem ser monitorados, a fim de observar a evolução e tendências, bem como detectar desvios e falhas. A equipe de partida, o coordenador de Parada, os especialistas e técnicos de operação devem ter a responsabilidade sobre esse acompanhamento, análise e diagnóstico.

Por fim, com o atendimento aos padrões de qualidade do produto desejados, a etapa 3 é dada como finalizada.

\subsubsection{Etapa 4 - Avaliação e perspectivas}

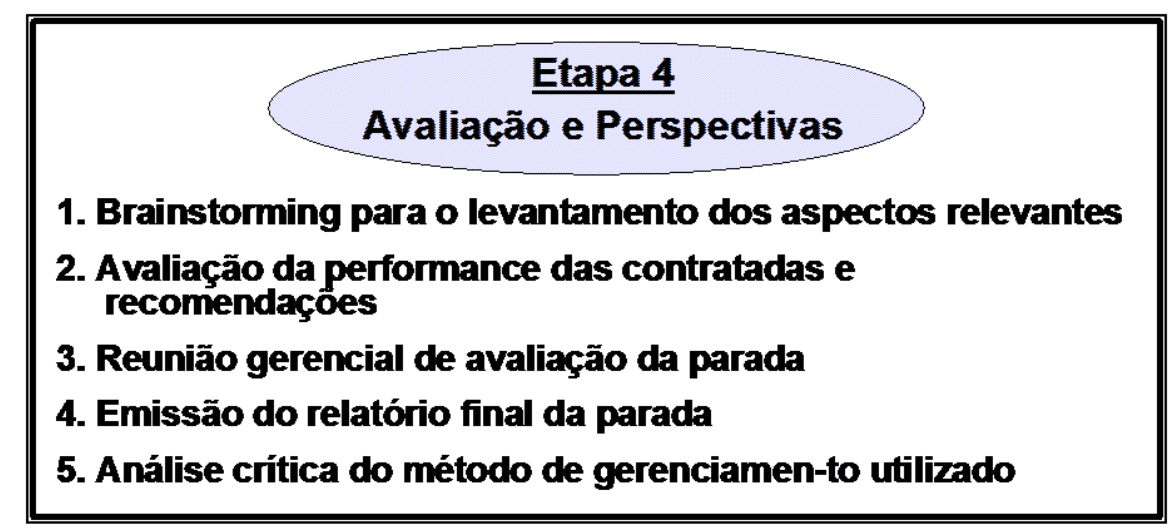

Figura 5.6 - Etapa 4: Avaliação e perspectivas.

\section{Brainstorming para o levantamento dos aspectos relevantes}

Com o processo de produção estabilizado e a qualidade do produto normalizada, os representantes dos grupos de trabalho e as pessoas chaves devem reunir-se, juntamente ao coordenador de parada, para o levantamento dos pontos de atenção observados no decorrer desta. Assim, devem ser relacionados os pontos fortes e fracos, principais desvios e falhas, acidentes, otimizações e ganhos obtidos. O Book da Parada, concebido durante a etapa 3, também tem grande contribuição nesse momento.

Em casos específicos, recomenda-se que esses encontros sejam realizados separadamente pelos grupos de trabalho, e as informações reunidas e centralizadas nos representantes. É importante notar que a participação dos profissionais diretamente envolvidos na execução dos trabalhos é fundamental. 
O principal objetivo é listar os aspectos relevantes de forma clara e sintética, para um auxilio na avaliação das contratadas, reunião gerencial de avaliação, relatório final da Parada e análise crítica da sistemática utilizada.

\section{Avaliação do desempenho das empresas contratadas e recomendações}

A partir da verificação do atendimento das normas, diretrizes, metas e penalizações contratuais, estabelecidas na etapa 2 (atividade 10), e com o acompanhamento do desempenho das contratadas, através da obtenção dos dados em verificações formais periódicas dos profissionais, atividades e serviços em desenvolvimento, realizadas na etapa 3, têm-se todas as informações para uma análise mais apurada do desempenho de atuação de cada empresa envolvida.

Dessa forma, aspectos referentes ao cumprimento das normas de segurança, responsabilidades contratuais, qualidade dos serviços e/ou recursos fornecidos, obtenção de metas e desafios estabelecidos etc., devem ser avaliados e comentados, com o objetivo de registrar a participação dessas empresas no histórico da Parada, corrigir desvios e irregularidades, bem como recomendar maiores cuidados em contratações futuras ou, até mesmo, desqualificações. Se necessário, a participação da(s) contratada(s) pode ser solicitada nessas avaliações, para maiores esclarecimentos e formulação de planos de ações futuras, sendo indispensável que seja mantida uma relação de transparência e confiança.

Os resultados e relatórios dessas avaliações devem ser encaminhados ao coordenador de Parada, e serão utilizados na reunião gerencial de avaliação e composição do relatório final da Parada. Recomenda-se também o encaminhamento dos mesmos as empresas em questão para comentários.

\section{Reunião gerencial de avaliação da Parada}

Com os dados obtidos nas fases iniciais dessa etapa, juntamente aos parâmetros de controle, gráficos, planos e cronogramas atualizados (com os apontamentos reais), reúnem-se as informações necessárias para a composição do histórico do evento, elaboração da lista de necessidades futuras (para a próxima parada), avaliação do atendimento dos desafios e performances, bem como as recomendações técnicas. Normalmente, para esse encontro recomenda-se o mesmo 
fórum das reuniões de gerenciamento global (atividade 7 da etapa 2) e reuniões gerenciais de acompanhamento de desempenho (atividade 5 da etapa 3 ).

O objetivo principal desta reunião é obter dados globais e acordados entre as áreas para a emissão do relatório final da Parada, sendo o coordenador de Parada o responsável pela sua realização e composição dos dados.

\section{Emissão do relatório final da Parada}

Em um trabalho conjunto entre o coordenador de Parada e as equipes de planejamento de manutenção, os resultados, perspectivas e recomendações compilados na reunião gerencial (atividade 3 desta etapa) devem ser transferidos de forma clara e sintética em um único documento. Recomenda-se a utilização de gráficos, fotos e tabelas, que facilitem a visualização das informações e valorizem as metas e desafios alcançados. Todos os aspectos relevantes e que necessitem de maiores detalhes devem ser anexados a parte ou encaminhados separadamente.

Após sua edição, o relatório final da Parada deve ser registrado, divulgado nas áreas e encaminhado a alta direção da empresa. É importante lembrar que este relatório será o principal ponto de partida para a próxima Parada, sendo utilizado na atividade 4 da etapa 1 desta.

\section{Análise crítica do método de gerenciamento utilizado}

Focando-se especificamente na "sistemática" utilizada para o gerenciamento e controle da Parada, busca-se a identificação das falhas e fragilidades observadas, bem como a discussão das modificações e otimizações necessárias. Para isso, recomenda-se a formação de um grupo multifuncional, multiespecialista e orientado pelo coordenador de Parada que, a partir de um visão global e sistêmica deve analisar os métodos aplicados e os resultados obtidos.

As técnicas e métodos utilizados com sucesso devem ser mantidos, e as fragilidades e fracassos observados revistos, eliminados ou reavaliados, a fim de se obter uma maior assertividade e eficácia no evento seguinte.

Deve-se esclarecer que a questão não é validar ou não a sistemática utilizada, mas sim promover um aperfeiçoamento contínuo e gradual de sua utilização e aplicação. 


\section{CAPITULO 06}

\section{CONCLUSÕES E PERSPECTIVAS}

\subsection{Conclusões Gerais da Pesquisa Desenvolvida}

O objetivo principal deste trabalho foi o desenvolvimento de uma sistemática de manutenção para o gerenciamento de PG em processos de produção de celulose e papel, a partir da definição de formas adequadas para a identificação, padronização e otimização das ferramentas e métodos utilizados, com a finalidade de garantir o sucesso no estabelecimento da estratégia da Parada, no planejamento e controle da execução de todas as atividades e na avaliação final da performance do evento, face ao papel estratégico desses empreendimentos no setor.

Para melhor compreensão dos resultados deste objetivo principal e dos secundários, têm-se as considerações a seguir:

Quanto ao atendimento do objetivo principal, observa-se na concepção da sistemática o estabelecimento de um modelo voltado à grandes empreendimentos, fundamentado no estudo de abordagens teóricas disponíveis e em uma verificação da prática empresarial de um evento de PG.

Para o desenvolvimento e detalhamento das etapas do método de gerenciamento proposto, buscou-se como bases de sustentação:

a) a caracterização dos eventos de PG nas indústrias papeleiras como grandes empreendimentos;

b) a aplicação de uma política de manutenção efetiva, disciplinada e adequada às necessidades do processo produtivo, caracterizada pela utilização de técnicas gerenciais, ferramentas específicas e ações com base na definição de uma forma de atuação estratégica na planta fabril; 
c) a utilização de conceitos, práticas, técnicas e ferramentas de gestão voltadas para a qualidade, visando a padronização de procedimentos, a uniformização da terminologia e a sinergia entre as equipes de manutenção e operação;

d) o suporte de sistemas informatizados, como os softwares de gerenciamento, planejamento e controle de manutenção, os especialistas de monitoramento contínuo e manutenção preditiva, e os de informações gerais (fluxo interno da organização);

e) a disseminação de uma cultura organizacional e comportamental voltada à gestão do conhecimento, à valorização das pessoas, ao bem estar do clima do ambiente de trabalho, e à mudança e melhoria contínuas;

f) a observação de algumas abordagens voltadas à modelos de gestão de paradas planejadas em processos de produção contínua, sob o enfoque prático e teórico; e g) a verificação da prática empresarial de um evento de PG.

Quanto às questões formuladas no item 1.4: (1) Como identificar, padronizar, tratar e controlar todos os detalhes que envolvem uma parada planejada geral em processos de fabricação de celulose e papel? e; (2) Quais características de gestão, conceitos, técnicas e ferramentas são necessárias para um gerenciamento efetivo e pró-ativo deste empreendimento?; verifica-se seu atendimento através da caracterização das paradas planejadas, revisões bibliográficas, verificação da prática empresarial, e desenvolvimento da sistemática de manutenção proposta.

Dentro de uma visão sintética, podem ser feitas algumas considerações sobre essas questões.

Nota-se nessas questões a complementaridade, sendo o monitoramento adequado de todos os detalhes dos eventos de parada da produção diretamente dependentes dos conceitos e técnicas de gestão implementadas. Na verdade, a sistemática desenvolvida propõe o gerenciamento das PG's a partir de um método orientativo voltado à utilização de práticas e ferramentas de análise e controle, bem como fundamentado na disseminação de uma cultura comportamental que pregue padronização, disciplina e comprometimento.

Com isso, observa-se que a realização de PG com sucesso nas indústrias do setor papeleiro requer uma preocupação efetiva com as atitudes dos profissionais envolvidos e, diante de uma competitividade muito acirrada nos mercados desse 
setor, um grande diferencial encontrado é o fator humano.

Nesse contexto, recomendou-se uma forma de gestão do processo produtivo sustentada numa política de manutenção estratégica e voltada para a qualidade, que tenha nas paradas planejadas e de oportunidade as bases para uma atuação conjunta entre as equipes de manutenção e operação. A máxima disponibilidade da planta fabril é a principal meta dessa gestão compartilhada.

Contudo, verificam-se alguns aspectos essenciais na realização da PG:

a visão desses eventos como uma estratégia de manutenção voltada as necessidades de mercado - as PG's devem ser vistas pela alta gerência como um foco de ganhos, tendo caráter estratégico para o negócio;

a gestão compartilhada da produção - uma atuação conjunta das equipes de operação e manutenção, diante das mesmas metas, desafios e responsabilidades (PARRILLA, OLIVEIRA \& DOVICO, 2001);

a disciplina na aplicação de práticas e ferramentas - com a padronização das ações, orientação e verificação do seu cumprimento efetivo através dos líderes;

a necessidade de um método para o gerenciamento das paradas - aqui caracterizado pela sistemática de manutenção proposta.

Quanto à verificação de um evento de PG na prática empresarial, o objetivo também foi atingido à medida que todas as particularidades do ambiente real, em uma empresa de fabricação de celulose e papel, foram observados, avaliados e considerados no desenvolvimento da sistemática de manutenção proposta. Com isso, também pôde-se mostrar o potencial de aplicabilidade dessa sistemática, com a caracterização das suas variações, a verificação das necessidades para a adequação de práticas, técnicas e ferramentas na implementação da mesma e a identificação de problemas potenciais, em virtude das particularidades do ambiente de produção.

\subsection{Impactos Esperados para o Negócio}

Os resultados globais das empresas do setor papeleiro são muito influenciados pela performance obtida nos momentos de intervenção na planta fabril, 
que por sua vez dependem diretamente das características do ambiente organizacional, principalmente no caso específico da PG.

$\mathrm{Na}$ verificação de uma prática empresarial como descrito no item 4.4, realizada na VCP_LA, notam-se vários benefícios inerentes à sua competitividade no mercado, otimização dos recursos e alavancagens de produtividade, resultado da busca contínua pelo aperfeiçoamento e organização da forma de gestão das Paradas.

Como principais exemplos desses benefícios, têm-se: redução do tempo de indisponibilidade total, redução de horas trabalhadas, redução do custo total de manutenção por tonelada produzida e alavancagens de produtividade.

\section{Redução do tempo de indisponibilidade total das Paradas Gerais}

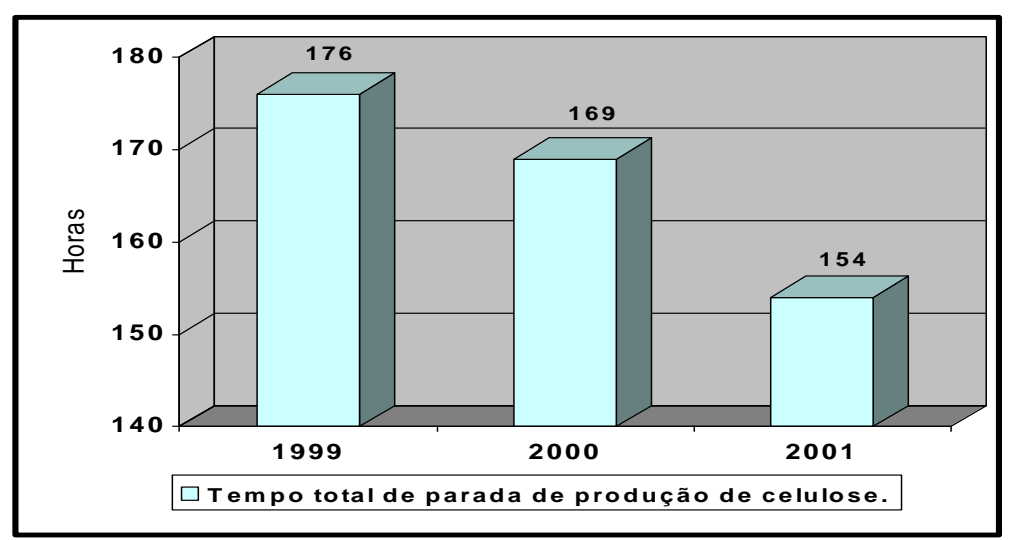

Figura 6.1 - Gráfico demonstrativo da redução do tempo total de indisponibilidade de produção de celulose nas últimas PG's.

Através dos históricos dos eventos de PG anteriores, observa-se uma redução do tempo de indisponibilidade total da planta de produção de celulose, como mostra a figura 6.1, caracterizando um sensível aperfeiçoamento na realização dos procedimentos operacionais, bem como uma maior assertividade de planejamento e programação das atividades e intervenções.

\section{Redução de horas trabalhadas em Paradas Gerais}

Normalmente, os gastos com serviços e mão-de-obra superam as despesas com materiais, sobressalentes e equipamentos nos eventos de PG realizados nas indústrias papeleiras, sendo essa situação suportada pela verificação da prática empresarial realizada no item 4.4 . 
Em virtude disso, a otimização dos recursos de mão-de-obra e serviços, a partir da redução das horas homens trabalhadas podem caracterizar um foco de ganho, face ao potencial de economia de custos para essas contratações.

$\mathrm{Na}$ figura 6.2 tem-se um gráfico que mostra a evolução das quantidades de horas homens realizadas nas últimas três PG's na CRU. É importante notar que a tendência de redução é linear a todas as especialidades envolvidas. Além disso, vale ressaltar que o volume de atividades realizadas manteve-se constante, demonstrando uma maior eficiência no momento da execução, com a menor ocorrência de falhas e retrabalhos.

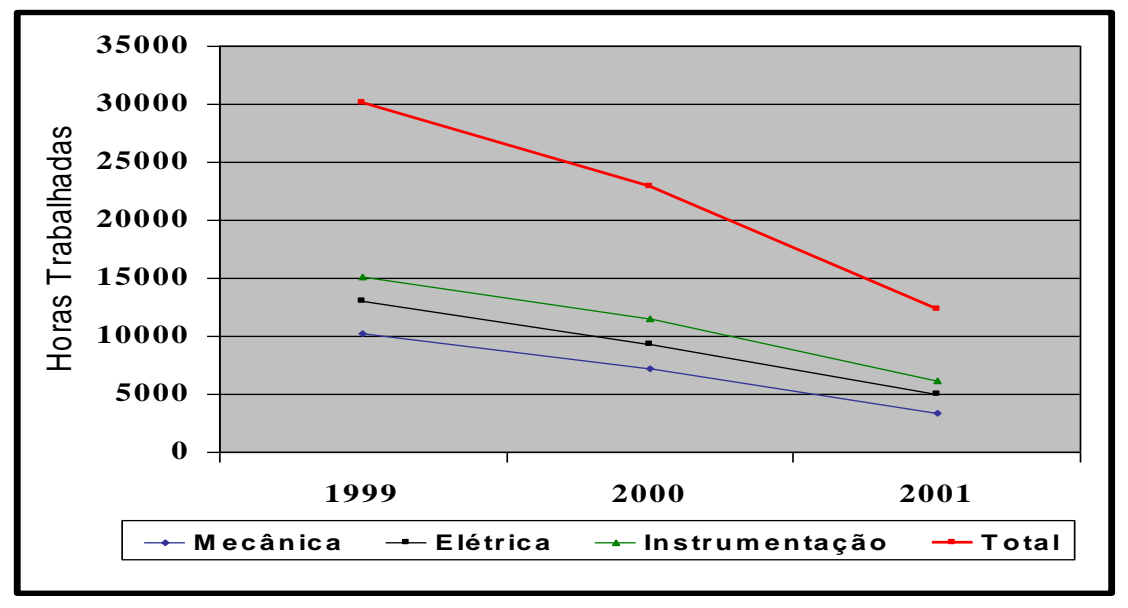

Figura 6.2 - Gráfico demonstrativo de redução de horas trabalhadas em PG na CRU.

\section{Redução do custo total de manutenção por tonelada produzida}

A confiabilidade e continuidade do processo, obtida com a busca pelo aumento do domínio do homem sobre a máquina e ações tomadas no momento das intervenções, podem resultar em reduções expressivas no custo total de manutenção relativo a tonelada de celulose produzida, como observado na figura 6.3. Nesse caso, o custo total de manutenção é referente a soma de todos os custos apontados nas contas específicas de manutenção da VCP para se produzir uma tonelada de celulose, ou seja, custos fixos, materiais e serviços de manutenção.

A figura 6.3 mostra a evolução do custo, em dólares (US\$), necessário para a produção de cada tonelada de celulose na VCP_LA. Nota-se uma redução de cerca de 48\% em cinco anos, passando de 34 dólares em 1996 para 18 em 2001. 


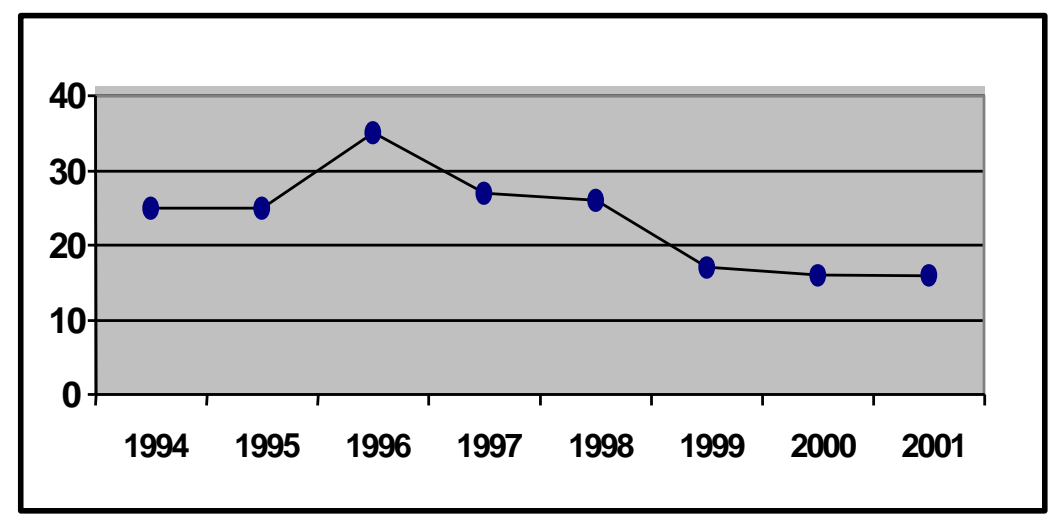

Figura 6.3 - Gráfico demonstrativo de redução do custo total de manutenção por tonelada de celulose produzida na VCP_LA.

\section{Alavancagens de produtividade}

O trabalho em conjunto entre as equipes de manutenção e operação, realidade na VCP_LA, compartilhando a gestão da produção, as metas gerenciais e os resultados do negócio, culminou numa visão global do processo e multiespecialista da tecnologia aplicada, proporcionando sua otimização e a melhoria contínua. Além da questão organizacional, a busca pela padronização, eficiência e eficácia das atividades de PG também contribuem nesses aspectos.

Neste sentido, como exemplo é apresentada na figura 6.4 a alavancagem da produção de toneladas de Sólidos Secos - tSS na CR, substância resultante da queima realizada na fornalha. Faz-se importante salientar que a área de queima da fornalha não foi alterada.

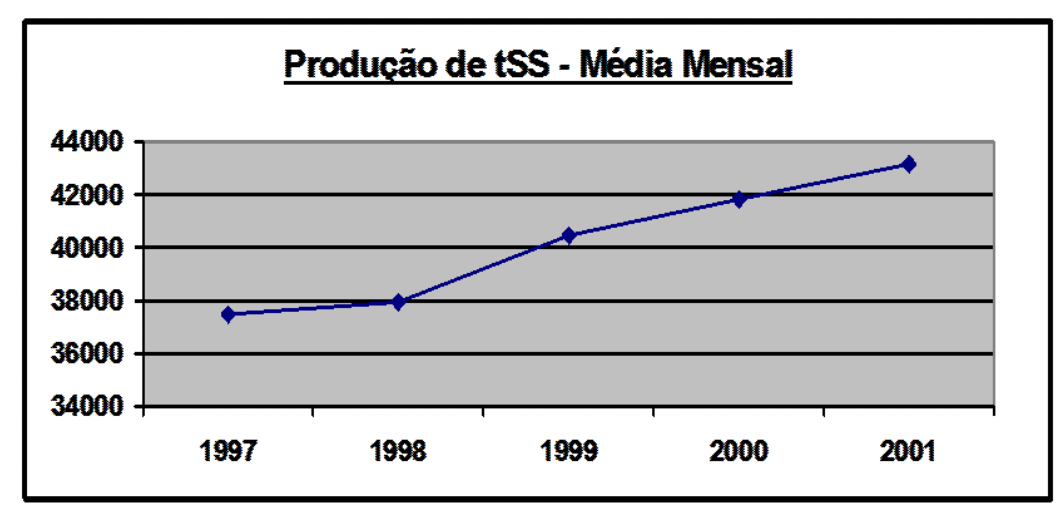

Figura 6.4 - Evolução da produção média de tSS ao ano na CR. 


\subsection{Contribuições da Sistemática Proposta para a Manutenção}

A implementação da sistemática de manutenção para gerenciamento de PG em processos de produção de celulose e papel, proposta no presente trabalho, beneficia a manutenção no setor em vários aspectos. Dentre eles, três podem ser destacados: o homem, a gestão e a estratégia de manutenção.

Como o sucesso desse método de gerenciamento está diretamente ligado ao grau de disciplina, organização e padronização alcançado pela empresa e seus funcionários, o desenvolvimento e capacitação do homem de manutenção tornou-se necessária e indispensável, face a disseminação e aplicação de conceitos, práticas, técnicas e ferramentas de apoio de forma efetiva e constante. Esse fato fez com que as indústrias do setor buscassem alternativas e investissem no aperfeiçoamento e atualização desses profissionais, promovendo uma atuação pró-ativa e uma visão sistêmica.

Nesse novo patamar de competência, os profissionais de manutenção começam a participar definitivamente da gestão do processo produtivo, contribuindo com análises e diagnósticos sob um enfoque técnico e especialista, mas com uma visão voltada a disponibilidade do processo produtivo, a confiabilidade operacional, a otimização de recursos e a competitividade do negócio.

Com isso, a gestão da manutenção vem sendo continuamente adequada para o compartilhamento das responsabilidades pela produção com a equipe operacional, bem como estruturada em função de uma estratégia de manutenção da planta fabril voltada para: monitoramento contínuo do processo, prática da Engenharia de Manutenção, aplicação de manutenções preditivas e detectivas, planos de inspeções periódicas, e a realização de intervenções apenas de forma planejada, possibilitando a utilização dos chamados "momentos de oportunidade" (MO), que caracterizam a forma de intervenção mais econômica nas indústrias papeleiras da atualidade.

Esses momentos são configurados por paradas ou reduções inerentes à operacionalidade do processo como, por exemplo: a realização de limpezas e inspeções, troca de fabricações e reduções de demanda entre os sub-processos; sendo encarados como oportunidades em potencial para a realização de intervenções de 
manutenção somente possíveis com os equipamentos parados ou em carga reduzida. Os serviços que detém essas características e estejam em carteira para a próxima PG (vide etapas 1 e 2 da sistemática de gerenciamento proposta no capítulo 5) apresentam um nível de detalhamento adequado para sua realização nesses momentos. Diante do surgimento de um momento ("janela") que torne isso possível, todo trabalho desenvolvido em função do planejamento da parada pode ser apropriado a essa oportunidade, junto ao grupo de trabalho responsável.

Neste sentido, a aplicação da sistemática possibilita a utilização desses momentos de forma estratégica, com a realização das intervenções com mais assertividade, segurança, qualidade, eficiência, cuidados com o meio ambiente e otimização de custos.

\subsection{A Manutenção, a Qualidade e o Conhecimento como Fatores Estratégicos}

Como principais parâmetros de suporte para a incorporação de novas estruturas organizacionais num ambiente altamente dinâmico e o atendimento das metas empresariais, bem como para manter-se competitivo no mercado globalizado, nas indústrias do setor papeleiro destacam-se as abordagens estratégicas para as políticas de gestão de "manutenção", da "qualidade" e do "conhecimento".

Neste contexto, os aspectos organizacionais e das relações humanas passaram a ser fundamentais, e as pessoas e suas atitudes os grandes diferenciais. Uma ampla visão do negócio, a prática de ações que agregam valores, a versatilidade para adquirir novos conhecimentos, a flexibilidade para adequar-se a um ambiente de contínua mudança e a facilidade para relacionar-se com as pessoas são alguns valores essenciais para manter e buscar mais competitividade e produtividade.

Assim, a aplicação de programas de gestão pela qualidade objetivam à promoção de mudanças na forma de pensar e agir das pessoas, a multifuncionalidade dos profissionais envolvidos, o alinhamento dos conceitos disseminados e a padronização das técnicas de atuação no processo.

Voltando-se especificamente a manutenção da planta fabril, a competência técnica do homem de manutenção já não basta, pois o mercado exige 
uma ampla visão do negócio, uma atuação compartilhada com a produção e uma contribuição efetiva no resultado final quanto as metas globais. Com isso, as equipes de manutenção tiveram de superar muitos obstáculos e aprender a ser mais versátil, evoluindo de um estágio onde o processo parava freqüentemente para a execução de várias intervenções preventivas periódicas, para outro onde as intervenções na planta ocorrem em Momentos de Oportunidade, Paradas Setoriais e Paradas Gerais, proporcionando maior disponibilidade, confiabilidade, otimização dos custos, qualidade no atendimento dos clientes, segurança e cuidados com o meio ambiente.

Para isso, a utilização de várias práticas de manutenção, como a Análise de Riscos Potenciais, a Análise de Problemas Potenciais, a Análise de Modo e Efeito da Falha, a Análise das Causas Raízes da Falha e a Análise de Árvore de Falhas, além de técnicas como a Manutenção Centrada em Confiabilidade e a prática efetiva da Engenharia de Manutenção, oferecem as bases que, aliadas aos conceitos de qualidade adotados, podem resultar em uma política de manutenção integrada, bem estruturada e sólida.

As manutenções de rotina, preventivas, preditivas e detectivas devem ser realizadas em conjunto com as equipes operacionais. Além disso, é indispensável uma atuação compartilhada e efetiva no acompanhamento e monitoramento do processo. A disciplina na consecução dessas ações, além da padronização das atividades desenvolvidas resultam em um perfeito e eficaz processamento na planta fabril e proporcionam uma atuação estratégica, consequiência direta do total domínio do homem sobre os equipamentos e processos.

\subsection{Perspectivas e Tendências}

De forma ampla, como principais perspectivas e tendências observadas no contexto do ambiente e dos assuntos abordados no presente trabalho, têm-se:

- a crescente valorização do fator humano;

- o inevitável suporte de softwares especializados;

- a gestão compartilhada do processo produtivo;

- e a indispensável sistematização dos eventos de PG. 
Contudo, os investimentos em novos conceitos, tecnologias e no contínuo desenvolvimento e capacitação dos profissionais de manutenção, diante organizações flexíveis e aptas às mudanças, são fatores fundamentais para as empresas que desejam manter-se competitivas nos mercados inerentes ao setor papeleiro.

Apesar da sistemática facilitar o gerenciamento e controle dos eventos de PG nas indústrias do setor papeleiro, a partir de um enfoque de manutenção voltado à grandes empreendimentos, o sucesso de sua implantação depende de treinamentos, da prática, do engajamento e da sinergia de todos os envolvidos, além do indispensável apoio da alta gerência, devido a necessidade da liberação de recursos.

A continuidade deste trabalho deve-se dar através da verificação de aplicações práticas dessa sistemática, tanto nas indústrias papeleiras quanto em outros setores de processamento contínuo, bem como seu aperfeiçoamento e adequação face a novas técnicas e ferramentas futuramente desenvolvidas. Uma análise mais profunda dos aspectos comportamentais relativos aos eventos de parada de produção, as ações de manutenção e a evolução do perfil do homem de manutenção configuram-se uma extensão para este trabalho. 


\section{$\underline{\text { ANEXO A }}$}

\section{RELATÓRIO GERENCIAL DE PARADA PROGRAMADA}

Planilha de indicadores de programação de manutenção (Relatório Final da Parada Geral 2001 da Unidade Industrial LA do Grupo VCP, julho de 2001). 


\begin{tabular}{|c|c|c|c|c|c|c|c|c|c|c|}
\hline \multicolumn{11}{|c|}{ 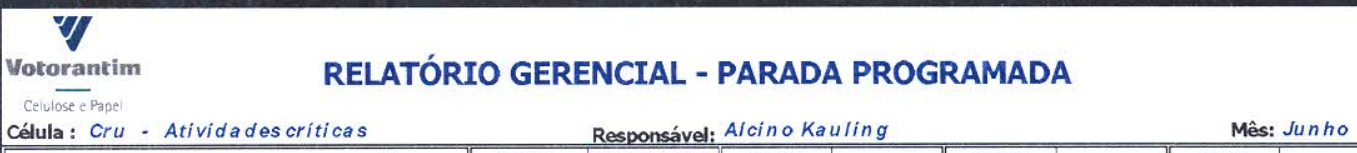 } \\
\hline \multirow{2}{*}{\multicolumn{3}{|c|}{$\begin{array}{c}\text { Equipamento : RECUPERAÇÃO E } \\
\text { UTILIDADES }\end{array}$}} & DATA: & $18-25 / 06 / 01$ & DATA: & & DATA: & & DATA: & \\
\hline & & & PLANO & REAL & PLANO & REAL & PLANO & REAL & PLANO & REAL \\
\hline \multirow{5}{*}{ 畩 } & \multirow{5}{*}{$\begin{array}{c}\text { homem } \\
\text { hora }\end{array}$} & Pessoas & 258 & 242 & & & & & & \\
\hline & & a - Disponiveis & 22540,0 & 21462,0 & & & & & & \\
\hline & & b- Estimadas & 22411,0 & 21341,0 & & & & & & \\
\hline & & c-Trabalhadas & 22411,0 & 21341,0 & & & & & & \\
\hline & & Variação $(+/-) b-c$ & & & & & & & & \\
\hline \multirow{4}{*}{ 蛋 } & \multirow{3}{*}{ Horánio } & Início & $2 h \mathrm{~h}-19 / 06$ & $20 \mathrm{hs} 18 / 06$ & & & & & & \\
\hline & & Término & $2 h 5-26 / 06$ & $06 \mathrm{hs} 25 / 06$ & & & & & & \\
\hline & & Decorrido & 168,0 & 154,0 & & & & & & \\
\hline & \multicolumn{2}{|r|}{ Variação (t/-) } & & 14,0 & & & & & & \\
\hline \multirow{3}{*}{\multicolumn{2}{|c|}{$\%$}} & Produtividade - $b / a$ & $99 \%$ & $99 \%$ & & & & & & \\
\hline & & Utilização - c/a & $99 \%$ & $99 \%$ & & & & & & \\
\hline & & Eficiência - b/c & $100 \%$ & $100 \%$ & & & & & & \\
\hline \multicolumn{11}{|c|}{ INTERRUPÇÕES E/OU DEMORA } \\
\hline$C O D$ & & crição do motivo & hh & $\%$ & hh & $\%$ & hh & $\%$ & hh & $\%$ \\
\hline 01 & \multicolumn{2}{|c|}{ ATRASO Na LIBERAÇ̄OO DO TANQUE OISSOLVEDOR } & $06: 00$ & $5.9 \%$ & & & & & & \\
\hline 01 & \multirow{2}{*}{\multicolumn{2}{|c|}{$\begin{array}{l}\text { RETRABALHO NAS SOLDAS DOS INTERNOS } \\
\text { TECESSIDADE DE VARIAS GAMAGRAFAS DEVIDO } \\
\text { RERABAS }\end{array}$}} & 08:00 & $7.8 \%$ & & & & & & \\
\hline 01 & & & 08:00 & $7.8 \%$ & & & & & & \\
\hline 01 & \multicolumn{2}{|c|}{$\begin{array}{l}\text { IESSECCDADE DE + } 30000 \text { P/ REPINAGEM } \\
\text { (TOTAL } 60002\end{array}$} & $12: 00$ & $11.8 \%$ & & & & & & \\
\hline 01 & \multirow{2}{*}{\multicolumn{2}{|c|}{$\begin{array}{l}\text { REPARO NO TUBO DE AGUA DO SOPRADOR } 27 \\
\text { TRAVAMEVTO OAS VALVULAS ROTATIVAS DO ECOE } \\
\text { BANK }\end{array}$}} & $04: 00$ & $3.9 \%$ & & & & & & \\
\hline 01 & & & $04: 00$ & $3.9 \%$ & & & & & & \\
\hline \multirow[t]{2}{*}{01} & \multirow{2}{*}{\multicolumn{2}{|c|}{ ATRASO NA LBERACC̃̃O DA CALEERA AXULLAR II }} & $60: 00: 00$ & $58.8 \%$ & & & & & & \\
\hline & & & & $0.0 \%$ & & & & & & \\
\hline \multicolumn{3}{|c|}{ TOTAL } & $06: 00$ & $100 \%$ & & & & & & \\
\hline
\end{tabular}

Relatório Gerencial de Parada Programada: Avaliação da performance dos recursos de mão-de-obra e desempenho dos planejadores de manutenção (assertividade de programação), a partir do confronto do plano com os apontamentos reais.

\section{Indicadores de Manutenção:}

- Produtividade: relação entre homem-horas estimadas totais e disponíveis (efetivo + contratada).

- Utilização: relação entre homem-horas realmente trabalhadas e disponíveis (efetivo + contratada).

- Eficiência: relação entre homem-horas estimadas totais e realmente trabalhadas.

Interrupções ou demora: Percentagem de tempo perdido durante as intervenções, ou seja, desvios do planejado. 


\section{ANEXO B}

CRONOGRAMA MASTER DA PG2001

Cronograma inicial da Parada Geral 2001 da Unidade Industrial Luiz Antônio do Grupo VCP (janeiro de 2001). 


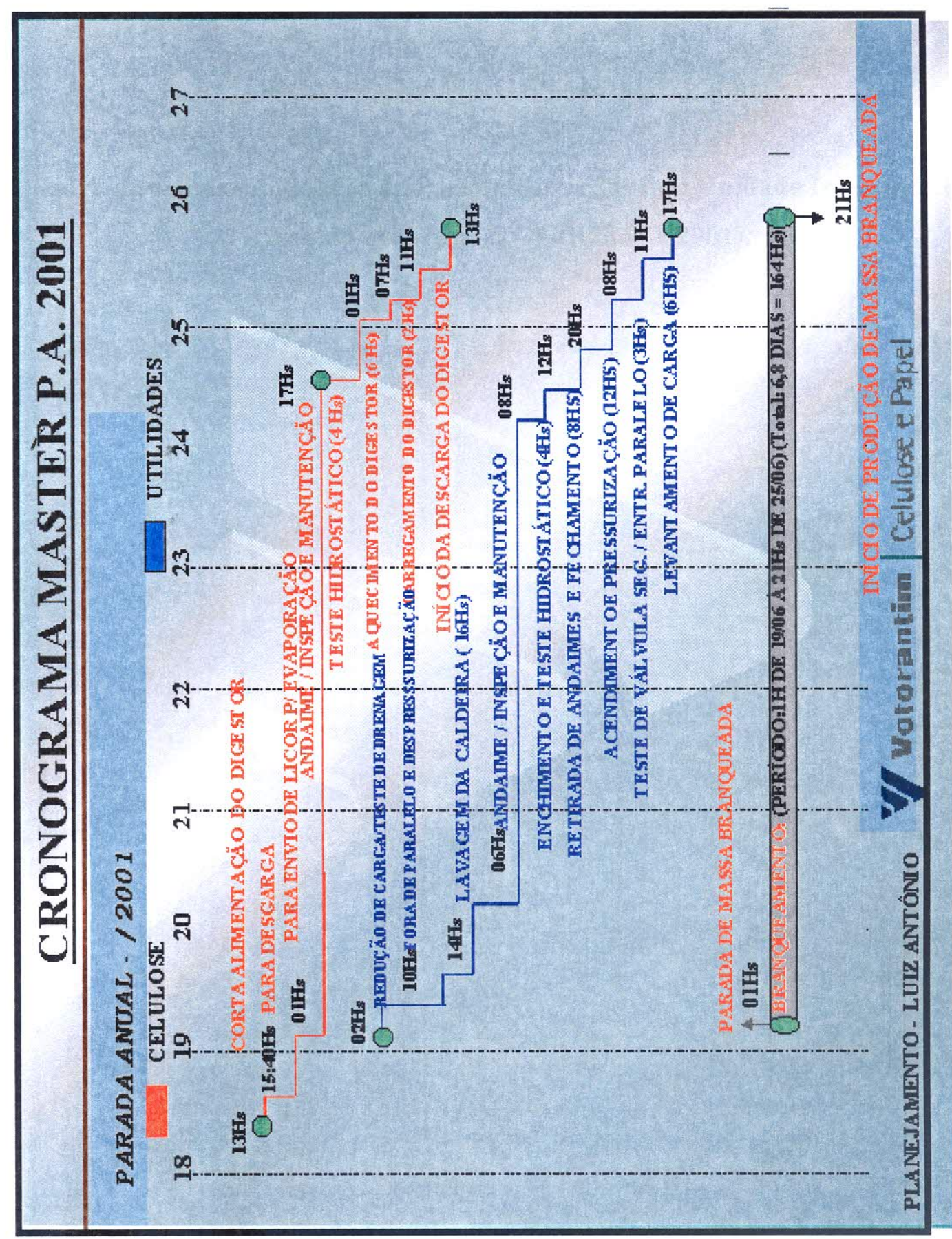




\section{$\underline{\text { ANEXO C }}$}

\section{ORGANOGRAMA GERAL DA PG 2001}

Quadro de responsabilidades da Parada Geral 2001 da Unidade Industrial Luiz Antônio do Grupo VCP (julho de 2001). 


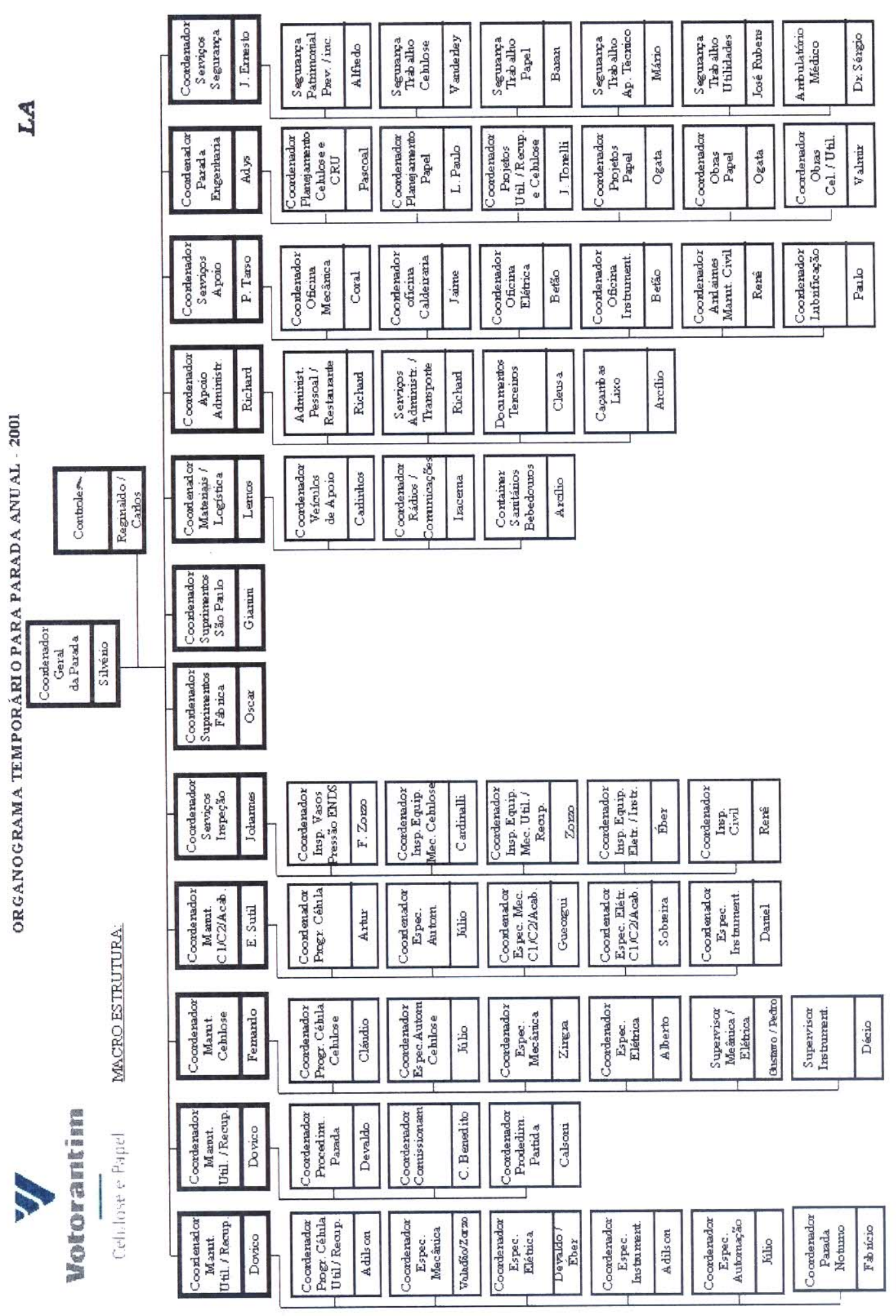




\section{ANEXO D}

\section{ANÁLISE DE RISCO POTENCIAL (ARP)}

Atividade realizada na Célula de Recuperação e Utilidades durante a fase de planejamento da Parada Geral 2001 da Unidade Industrial Luiz Antônio do Grupo VCP (maio de 2001). 


\section{Votorantim | Celulose e Papel}

\section{ANALISE DE RISCO POTENCIAL}

Evento: Parada Geral Anual 2001 - CRU.

Data da análise: 17/ 12/2000.

Área: Caldeira de Recuperação.

Grupo de analise: Alcino, Carlos Benedito, Roberto Villarroel, Luis Evangelista, Valadão, Adilson Cruz, Larry, Wagner (ABS), Alexandre (ABS), Sergio Ricardo, Dovico e Fabrício.

Ferfamenta Utilizada: Analise de Risco Potencial - ARP.

Objetivo da ARP: Identificar e analisar criteriosamente os caminhos críticos antecipadamente, definir responsáveis e traçar plano de ação, visando a execução das atividades conforme o planejado, sem acidentes e sem atrasos no retorno.

\section{Identificacão e Analise dos Caminhos Críticos}

1. Parada da Caldeira:

> Atraso na liberação pela operação (Carlos Benedito).

- Administração do estoque de licor preto forte;

> Não cumprimento do horário de término do envio do licor do Digestor para a Evaporação.

2. Hidrojateamento:

- Liberação do cartão vermelho (Irita)

- Integração da equipe do hidrojato (José Rubens)

- Documentação / crachás. (Luís Evangelista)

> Definição de equipe para efetivar bloqueios. (Evandro)

- Abertura de linhas e válvulas. (Sérgio Ricardo)

- EPI's para equipe de hidrojato - Chamar supervisor com 01 dia de antecedência. (José Rubens)

- Equipamentos e ferramentas para hidrojato (José Rubens)

> Liberação do tanque dissolvedor - Segurança / Bloqueio (Carlos Benedito)

3. Limpeza dos Precipitadores I e II:

- Fechamento do disc dumper. (Sérgio)

- Programação redução de carga - Operação SDCD. (Carlos Benedito)

- Liberação do cartão vermelho / ambiente confinado. (Carlos Benedito)

- Falta EPI's para acesso interno. (José Rubens)

- Coordenação inspeção / limpeza. (Florisvaldo)

> Análise / inspeção dos desligamentos constantes do PE I. (Devaldo) 
4. Revisão nos mancais dos ventiladores 005/007/003/009:

> Chamar a "Mobil" - Análise da lubrificação. (Dovico)

- Liberação do cartão vermelho. (Irita)

> Previsão / verificação sobressalentes. (Luís Evangelista)

- Envolver ABB - Análise de vibração. (Valadão)

> Limpeza dos rotores. (Carlos Benedito)

\section{Evaporação:}

- Atraso na liberação dos efeitos. (Irita)

> Desmontagem e montagem das bombas no local. (João Carlos)

- Revisão na oficina central. (Coral)

> Previsão/ verificação sobressalentes - selos mecanismos. (Luís Evangelista)

- Envolver ABB. (Valadão)

\section{Administração/ Logística:}

- Ajustar horários do almoço - todos os envolvidos. (Luís Evangelista)

> Buscar equipe VCP às 05:00hs. (Luís Evangelista)

> Documentação/ integração/ liberação da M.O contratada. (José Rosa)

$>$ Providenciar lanches para equipe que entra antes das 08:00hs. (Tomio)

- Ajustéde freqüência dos rádios. (Evandro)

- Administração da iluminação. (Luís Cláudio)

- Envolver Almoxarifado. (Fabrício)

Envolvidos: Adilson Cruz, Carlos Benedito, Irita, José Rubens, Luis Evangelista, Evandro, Sergio, Tico, Devaldo, Dovico, Valadão, Coral, José Rosa, Tomio, Luis Claudio, Fabrício, ABS, ABB, Roberto Villarroel, F. Zorzo e Flavio (Almox.).

Importante: Todos os responsáveis diretos por cada item, deverão ir ao local do trabalho e elaborar plano de ação, de tal forma à apresenta-lo para discussão e ajustes (se necessário) com todos os envolvidos na parada, em reunião abaixo definida:

Data: 09/02/2001.

Hora: 15 horas.

Local: Sala de Reuniões CPU.

\section{Contamos com sua participação!}




\section{$\underline{\text { ANEXO E }}$}

\section{FOLHA DE RESULTADOS GERAIS}

Contra-capa do Relatório Final da Parada Geral 2001 da Unidade Industrial Luiz Antônio do Grupo VCP (julho de 2001). 


\section{PARADA ANUAL 2001 - CELULOSE E RECUPERAÇÃO}

\section{RESULTADOS}

1 - PERÍODO DA PARADA: DE 18 À 26/06/2001

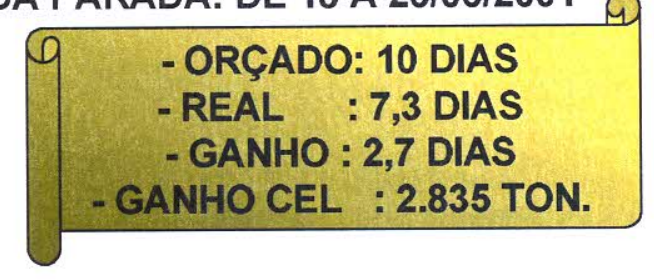

2 L QUANTIDADE DE SERVIÇOS: 2.152 O.S.'s

3 - MOBILIZAÇÃO DE PESSOAL DE TERCEIROS: 2.015 PROFISSIONAIS

4 - QUANTIDADE DE EMPRESAS MOBILIZADAS: 109

5 - PESSOAL CEDIDO POR EMPRESAS VCP: 02 DA UNIDADE JACAREÍ

6 - DESPESAS: ORÇADO: $\mathbf{R} \$ 3.296,43 \mathrm{MIL}$

PROJETADO 03/07: R\$3.503,42 MIL

7 - SEGURANÇA:

NÃO HOUVE FATOS DE MAIOR GRAVIDADE NA PARADA ANUAL 2001

8 - RESTAURANTE CENTRAL: REFEIÇÕES: 13.190

LANCHES: 8.673

9 - ESTADO DOS PRINCIPAIS EQUIPAMENTOS:

BOM, SEM PENDÊNCIAS 


\section{REFERÊNCIAS BIBLIOGRÁFICAS}

ASSOCIAÇÃO BRASILEIRA DE NORMAS TÉCNICAS (1998). NBR 13 - Norma regulamentadora de vasos de pressão e caldeiras. Rio de Janeiro, ABNT.

ASSOCIAÇÃO BRASILEIRA DE MANUTENÇÃO. (1998). Curso de gerência da manutenção, 12. São Paulo, ABRAMAN. 2v. /Apostila/

ASSOCIAÇÃO BRASILEIRA DE MANUTENÇÃO. (1998). Histórico e tendências na térceirização de serviços de manutenção. In: ENCONTRO NACIONAL DE RECURSOS HUMANOS NA MANUTENÇÃO, 7. São Paulo, ABRAMAN. /Apostila/

ASSOCIAÇÃO BRASILEIRA DE MANUTENÇÃO (1999). Documento nacional (Disquete). Rio de Janeiro, ABRAMAN.

ASSOCIAÇÃO BRASILEIRA DE MANUTENÇÃO (1999). Principais ferramentas da qualidade para a manutenção e a produção. São Carlos, ABRAMAN. /Apostila/

ASSOCIAÇÃO BRASILEIRA DE MANUTENÇÃO. (2000). Influencia do software na melhoria do gerenciamento da manutenção. São Carlos, ABRAMAN. /Apostila/

ABREU, R. L. (1991). CCQ, circulos de controle da qualidade: a integração trabalho - homem - qualidade total. 2.ed. Rio de Janeiro, Qualitymark / Petrobrás.

ABS SERVIÇOS S/C (2001). Manual de gestão - sistema de gestão da produtividade. Luiz Antônio, s.n.t. /Apostila/ 
AGUAYO, R. (1993). Dr. Deming: o americano que ensinou a qualidade total aos japoneses. Trad. por Luiz Carlos do Nascimento Silva. Rio de Janeiro, Record.

ANDRADE, M. M. (1999). Como preparar trabalhos para cursos de pósgraduação. 3.ed. São Paulo, Atlas.

ANHESINE, M. W. (1999). Uma abordagem sistêmica para diagnósticos em manutenção industrial. São Carlos. 204p. Tese (Doutorado) - Escola de Engenharia de São Carlos, Universidade de São Paulo.

BOARETO, P. (1985). Curso integrado de celulose e papel. Mogi Guaçú. s.n.t. tApostila/

BORGES, F. S. (1988). Visão prática e critica do planejamento e execução de grandes paradas de manutenção. In: CONGRESSO BRASILEIRO DE MANUTENÇÃO, 3., Salvador, 1988. Anais. São Paulo, ABRAMAN. p. 380

BRANCO FILHO, G. (2000). Dicionário de termos de manutenção, confiabilidade e qualidade. Rio de Janeiro, Ciência Moderna.

CAPO, P. (1999). Setor precisa investir para não perder a condição de exportador em 2005. Revista O Papel, Ano LX, nº 10, p.38-40, out.

CAPO, P. (1999). Tecnologia: momento atual, evolução e desafios futuros. Revista O Papel, Ano LX, n 10, p.41-45, out.

CAPO, P. (2000). Papel e Internet: será possível conviver por muito tempo? Revista O Papel, Ano LXI, n 12, p.52-55, dez.

CAstro, D. A.; SOUZA, M. S. B.; SilvA, A. C. P. (1992). Planejamento informatizado de paradas de plantas industriais. In: CONGRESSO BRASILEIRO DE MANUTENÇÃo, 7., São Paulo, 1992. Anais. São Paulo, ABRAMAN. p. 87 
CHIAVENATO, I. (1990). Iniciação ao planejamento e controle da produção. São Paulo, McGraw-Hill.

DOVICO, E. (2000). Transferência de conhecimento - perfil do profissional de manutenção. Luiz Antônio, s.n.t. /Apostila/

DRESSER, B.; CANIPE, R. (2000). Shutdowm and outage management. In: ANNUAL PAPER INDUSTRY RELIABILITY \& MAINTENANCE CONFERENCE AND EXHIBITION, 14., Atlanta, 2000. Anais. Atlanta, TAPPI. p. 82

DRUCKER, P. F. (1995). Administrando em tempos de grandes mudanças. Trad. por Nivaldo Montingelli Jr. São Paulo, Pioneira.

CAMPOS, V. F. (1992). TQC: controle da qualidade total (no estilo japonês). Belo Horizonte, UFMG/ Escola de Engenharia/ Fundação Christiano Ottoni.

CAMPOS, V. F. (1995). O valor dos recursos humanos na era do conhecimento. Belo Horizonte, Ed. Desenvolvimento Gerencial.

CAMPOS, V. F. (1998). Gerenciamento da rotina do trabalho do dia-a-dia. Belo Horizonte, Ed. Desenvolvimento Gerencial.

CORREAA, H. L.; GIANESI, I. G. N. (1993). Just in time, MRP II e OPT: um enfoque estratégico. 2.ed. São Paulo, Atlas.

FAESARELLA, I.S.; SACOMANO, J.B.; CARPINETTI, L.C.R. (1998). Gestão das qualidade: conceitos e ferramentas. São Carlos, USP-EESC. /Apostila/

FRIGGI, S.J.R. (2001). Organização de parada geral na industria de papel. In: SEMINÁRIO DE PLANEJAMENTO E CONTROLE DA MANUTENÇÃO, Belo Horizonte, 2001. Anais. Belo Horizonte, ABRAMAN. p. 23 
GOMES, E. R. (1998). Curso de pilares TPM - total productive maintenance. Ribeirão Preto, IMC International \& JIPM.

HAMMER, M.; CHAMPY, J. (1994). Reengenharia: revolucionando a empresa em função dos clientes, da concorrência e das grandes mudanças na gerência. Trad. por Ivo Korytowski. Rio de Janeiro, Campus.

IMAI, M. (1992). KAIZEN - a estratégia para o sucesso competitivo. São Paulo, IMAM.

IPT-SENAI (1988). Celulose e papel - tecnologia de fabricação da pasta celulósica. 2.ed. São Paulo, IPT/Departamento de Divulgação. .2.

TORRES JÚNIOR, A. S.; MARCHIORI, N. L. (2000). Pequeno dicionário de termos da empresa globalizada. São Paulo, Alfa-Omega.

FERREIRA JÚNIOR, M. (1996). Redução de paradas aleatórias com a utilização da metodologia de priorização e tratamento dos problemas de manutenção. In: CONGRESSO BRASILEIRO DE MANUTENÇÃO, 11., Belo Horizonte, 1996. Anais. São Paulo, ABRAMAN.

JURAN, J. M. (1992). Juran planejando para a qualidade. Trad. por João Mário Csillag; Cláudio Csillag. 2.ed. São Paulo, Pioneira.

JURAN, J. M. (1993). Juran na liderança pela qualidade. Trad. por João Mário Csillag. 2.ed. São Paulo, Pioneira.

KEPNER, C. H.; TREGOE, B. B. (1995). O novo administrador racional. Trad. por Joseph M.Luyten; M.Cristina Kruger. São Paulo, Makron.

KOTTER, J. P. (1997). Liderando a mudança. 6.ed. Rio de Janeiro, Campus. 
KRÖNER, W. (1999). Produtividade e qualidade na manutenção. São Paulo, ABRAMAN.

MONCHY, F. (1989). A Função manutenção - formação para a gerência da manutenção industrial. São Paulo, EBRAS/ DURBAN.

MCNUTT, J. A.; RENNEL, J. (1997). The future of fiber in tomorrow's world. PPI, v. 42, n 11, p.34-36, Jan.

MOUBRAY, J. (1997). RCMII - Reliability-centred maintenance. 2.ed. Londres, Aladon.

i

NAGAO, S. K. (1998). Manutenção industrial - análise, diagnóstico e propostas de melhoria de performance em indústrias de processo. São Paulo. 231p. Dissertação (Mestrado) - Escola Politécnica, Universidade de São Paulo.

NAKAJIMA, S. (1989). Introdução ao TPM - total productive maintenance. Trad. por Mario Nishimura. São Paulo, IMC Internacional Sistemas Educativos.

PARRILlA, F. R.; OLIVEIRA, J. S.; DOVICO, E. (2001). Manutenção - gestão compartilhada com a produção, uma experiência de sucesso na Votorantim Celulose e Papel. In: CONGRESSO BRASILEIRO DE MANUTENÇÃO, 16. \& CONGRESSO IBERO AMERICANO DE MANUTENÇÃO, 11., Florianópolis, 2001. Trabalho Técnico 113. Rio de Janeiro, ABRAMAN.

PASQUA, M. C. (1999). Desenvolvimento de uma sistemática para padronização e gerenciamento da programação da manutenção a partir de conceitos da qualidade. São Carlos. 128p. Dissertação (Mestrado) - Escola de Engenharia de São Carlos, Universidade de São Paulo.

PINTO, A. K.; XAVIER, J. N. (1999). Manutenção função estratégica. 2.ed. Rio de Janeiro, Qualitymark. 
RIBEIRO, H. (1994). 5S: a base para a qualidade total. Salvador, Casa da Qualidade.

SALERNO, M. S. (1994). Trabalho e organização na empresa industrial integrada e flexivel - novas tecnologias, trabalho e educação. São Paulo, FEI. /Apostila/

SAVASTANO, R. M. (2000). Projeto genoma do eucalipto pode trazer ganhos valiosos ao setor no Brasil. Revista O Papel, Ano LXI, nº 12, p.44-45, dez.

SAVASTANO, R. M. (2000). Resultados 2000 do setor comprovam seu peso na balança comercial superavitária do país. Revista O Papel, Ano LXI, n 12, p.2627, dez.

SILVA, J. C. (1992). Paradas: parceria como estratégia empresarial. Revista Manutenção, $\mathrm{n}^{\mathrm{o}} 34, \mathrm{p} .22$, jan.

SLACK, N. (1999). Administração da produção. São Paulo, Atlas.

STONNER, R. (2001). Ferramentas de planejamento - utilizando MS project para gerenciar empreendimentos. Rio de Janeiro, E-papers Serviços Editoriais.

STAGLIORIO, C. A. (1986). Eficácia em paradas de manutenção. In: CONGRESSO BRASILEIRO DE MANUTENÇÃO, São Paulo, 1986. Anais. São Paulo, ABRAMAN. v.1, p.258.

TABACOF, B. (2000). Papel e celulose: balanço de 2000 mostra virada do jogo dos maus tempos. Revista O Papel, Ano LXI, n 12, p.25, dez.

TAVARES, L. A. (1996). Excelência na manutenção - estratégias para otimização e gerenciamento. Salvador, Casa da Qualidade. 
TAVARES, L. A. (1999). Administração moderna da manutenção. Rio de Janeiro, Novo Polo.

UNIVERSIDADE DE SÃO PAULO. Escola de Engenharia de São Carlos. Serviço de Biblioteca (1996). Diretrizes para elaboração de dissertações e teses na EESC-USP. 2.ed. São Carlos, SVBIBL.

VOTORANTIM CELULOSE E PAPEL. Unidade Luiz Antonio (2000). Processos de fabricação - fluxos e fases da produção. Luiz Antônio, s.n.t. /Apostila/

VERRY, L. A. (1998). Sucesso em paradas de manutenção. In: CONGRESSO , BRASILEIRO DE MANUTENÇÃO, 13., Salvador, 1998. Trabalho Técnico 063, Rio de Janeiro, ABRAMAN.

VERRY, L. A. (2000). Planejamento e controle de paradas. São Paulo, ABRAMAN. /Apostila/

VIANNA, M. C. S. (1998). Planejamento e controle de paradas de manutenção: curso de otimização da manutenção. Rio de Janeiro, ABRAMAN. /Apostila/

VIEIRA, M. G. (1991). Características gerais da manutenção. São Carlos, EESC/USP. /Apostila 018/92/

VIEIRA, M. G. (1991). Introdução à manutenção. São Carlos, EESC/USP. /Apostila 017/92/

ZANUtTO, R. A.; CONSTANTINO, S.; GANTUS, C. (1998). Gestão pela qualidade. São Paulo, Ogra Indústria Gráfica. 


\section{GLOSSÁRIO}

Segue abaixo lista dos termos mais usuais na área de manutenção e no setor papeleiro, utilizados neste trabalho, para facilitar a compreensão do texto.

A maioria dos termos constam do "Dicionário de Termos de Manutenção, Confiabilidade e Qualidade - Edição Mercosul" de Gil Branco Filho, e do "Pequeno Dicionário de Termos da Empresa Globalizada" de Alvair Silveira T. Júnior e Nilton Luiz Marchiori, da Editora Alfa-Omega, ambos lançados em 2000 e aprovados pela ABRAMAN - Associação Brasileira de Manutenção.

Paráa alguns termos utilizados referentes ao processo de fabricação realizado na Unidade Industrial Luiz Antônio do Grupo Votorantim Celulose e Papel, constam da interpretação do autor, sendo baseados em pesquisas informais nesse ambiente.

"ACABAMENTO" - Nesta fase as bobinas podem ser embaladas, cortadas em grandes formatos (folio size) ou em pequenos formatos (cut size). Para a produção de papéis nesses formatos, têm-se cortadeiras e embaladeiras automáticas especiais.

AÇÃO DE MANUTENÇÃO - Seqüência de atividades elementares de manutenção efetuadas com uma dada finalidade. Como exemplo de tais ações, tem-se o diagnóstico da pane, a localização da pane, a verificação do funcionamento e suas combinações. (NBR 5462-1994)

"ALIMENTAÇÃO DO SISTEMA" - Inclusão dos dados verificados nas áreas de trabalho nos sistemas informatizados.

"ALVURA" - Característica inerente a brancura da pasta celulósica ou papel, tanto durante o processo como no produto final. Normalmente é medida por instrumento específico em "\%ISO" (unidade de medida de alvura).

ANÁLISE CRÍTICA - (Review). Avaliação profunda e global de um projeto, produto, serviço, processo ou informação com relação a requisitos, objetivando a identificação e a proposição de soluções. (Com base em diversas definições da NBR ISSO 8402-1994)

"AR DE FÁBRICA" - Ar comprimido distribuído por linhas para todas as áreas da fábrica, normalmente utilizado para limpezas, testes etc. 
"AR DE INSTRUMENTO" - Ar comprimido filtrado para alimentação de instrumentos e equipamentos específicos.

$\boldsymbol{B} \boldsymbol{A} \boldsymbol{C K} \boldsymbol{L} \boldsymbol{O} \boldsymbol{G}$ - Tempo que uma equipe de manutenção deve trabalhar para concluir todos dos serviços pendentes, com toda a sua força de trabalho, e se não forem adicionadas novas tendências durante a execução dos serviços até então registrados e pendentes em posse da equipe de Planejamento e Controle de Manutenção. Como se sabe, os atrasos ou pendências podem ser por falta de mão-de-obra, falta de material ou sobressalentes, falta de máquina não liberada ou aguardando outra equipe interferindo no trabalho.

BANCO DE DADOS DE MANUTENÇÃO - Conjunto de informações referente à manutenção, ao seu pessoal, aos eventos e ocorrências com as máquinas, seu cadastramento e seus códigos, podendo ser informatizado ou não. A finalidade de um bando de dados computadorizado de equipamentos existentes em uma unidade, (seja predial, industrial, de serviços ou qualquer outra) é proporcionar um acesso mais rápido e sistemático às características e eventos relacionadas com determinada mnáquina, item, sistema ou unidade.

BENCHMARK - Palavra de origem inglesa que indica o uso dos melhores resultados conhecidos para comparação com os parâmetros analisados. Na área de qualidade, deve-se buscar como referência, como "Benchmark", os melhores valores de desempenho de lideres reconhecidos como tais e que deverão contentar apenas em ser os melhores nacionais. Deveremos ser os melhores do mundo. Ver também Referencial de Excelência.

BENCHMARKING - Na área da qualidade é a comparação com referências de excelência, é a atividade de comparar um processo com líderes reconhecidos para identificar a oportunidade para a melhoria da qualidade (NBR ISSO 9004-4). É a metodologia de comparação sistemática de produtos e de serviços com os que são oferecidos por outras empresas, os concorrentes, e que são aceitas como excelentes. Com isto se consegue conhecer e adicionar ao nosso processo, o que está sendo feito de melhor, mais barato ou mais eficiente. Pode ser interno se a comparação é feita dentro de atividades idênticas na empresa ou externo quando compara a atividade com empresas similares externas. É um processo contínuo, que pode incluir comparações de estratégias, produtos, serviços, operações, processo procedimentos. Essa comparação deve ser feita inclusive com líderes de outro ramo que não o da organização.

"BOCAS DE VISITA" - Aberturas laterais em equipamentos, dutos e tubulações, normalmente de diâmetro reduzido (na medida somente para observação ou passagem de uma pessoa).

BRAINSTORMING - Literalmente "brain-storm" quer dizer "tempestade mental". Brainstorming é um livre debate onde as pessoas participantes dão idéias e sugestões, por mais esquisito que possa parecer sobre um determinado tema, ou seja um procedimento utilizado para que seja obtido, normalmente em uma sala com pessoas reunidas, um máximo de idéias e sugestões sobre um determinado assunto. Todos os participantes devem registrar qualquer pensamento ou idéia sobre o assunto para que 
ao final seja feito um estudo sobre as melhores idéias e sugestões. Na área da qualidade utiliza-se este processo para gerar as possíveis causas de um não atendimento do especificado. Após serão eleitas as causas mais prováveis e estudado como evitar que ocorram.

"BRANQUEAMENTO" - Sétima fase do processo de celulose da VCP_LA. Aqui ocorre o branqueamento $E F C$, que consiste na retirada de lignina restante e no aumento da alvura da polpa, o que é conseguido com a aplicação de alguns reagentes químicos.

"CALANDRAGEM" - Sétima etapa do processo de produção de papel da VCP_LA. A calandragem é um processo mecânico onde a superfície do papel é tratada, ou seja, refinada para a utilização em processos futuros e impressão.

“CALDEIRAS (À VAPOR)" - São equipamentos destinados a produzir e acumular vapor sob pressão superior à atmosférica, utilizando qualquer tipo de energia. Neste trabalho foram observadas a caldeira de recuperação e de força. A primeira queima os resíduos provenientes do processo e a segunda biomassa. Ver também vaso de pressão.

"CAMINHO CRÍTICO" - Seqüência de tarefas onde o atraso de uma delas fatalmente atrasará toda obra, projeto ou empreendimento.

"CARRO-CHEFE" - Ver caminho crítico.

“CARTÃO VERMELHO” - Documento em papel cartão vermelho utilizado para registro e bloqueio do sistema de acionamento dos pontos de energia dos equipamentos e sistemas. É indispensável para toda e qualquer intervenção na planta fabril, sendo preenchido por profissionais de operação e manutenção, e auditados pela equipe de segurança industrial.

CAUSA DA FALHA - Circunstâncias relativas ao projeto, fabricação ou uso que conduzem a uma falha. (NBR 5462-1994).

“CÉLULA DE TRABALHO" - Setor, departamento, seção. Nome dado aos departamentos produtivos e administrativos da VCP_LA após o Projeto Repensar.

CHECK LIST - Ver lista de verificação.

CICLO DE VIDA - (Life Cycle) - Tempo durante o qual um item conserva a sua capacidade de utilização. O período compreende desde sua aquisição até que é substituído ou é objeto de Restauração/Reforma.

“CICLO FECHADO" - Neste trabalho, significa um processo de produção onde todos os produtos inerentes são reaproveitados, com a máxima redução das perdas.

"CLASSIFICAÇÃO E ESTOCAGEM" - Quarta fase do processo de celulose da VCP_LA. Consiste na separação dos cavacos de acordo com seu tamanho, através de peneiras classificatórias. Os cavacos podem ser os "oversizes", que dificultam a impregnação do reagente, os "aceitos", que facilitam o controle do processo, ou os 
"finos", que degradam-se rapidamente, dificultando o cozimento no Digestor.

"COLAGEM ACIDA" - Processo onde as fibras da madeira são misturadas com substâncias diversas, resultando em um subproduto acido $(\mathrm{pH}<7)$.

"COLAGEM ALCALINA" - Processo onde as fibras da madeira são misturadas com substâncias diversas, resultando em um subproduto alcalino $(\mathrm{pH}>7)$. É o processo atualmente utilizado na VCP_LA.

COMPONENTE (Part) - Unidade pertencente a um conjunto, que geralmente não é funcional por si mesma, e está formada por peças (rotor de turbina, rolamento, cilindros de um motor). Parte de uma unidade, instalação ou equipamento que é essencial ao seu funcionamento.

CONFIABILIDADE - Capacidade de um item desempenhar uma função requerida sob condições especificadas, durante um intervalo de tempo. O termo confiabilidade é usado como uma medida de desempenho de confiabilidade. NBR 5462-1994 2.2.6.) Seu símbolo é $\mathrm{R}(\mathrm{t})$ - Reliability, de uso recomendado, apesar de alguns autores usem P (t) - probabilidade de sobrevivência. Probabilidade de um item poder desempenhar uma função requerida, sob dadas condições, durante um intervalo de tempo $(\mathrm{t} 1, \mathrm{t} 2)$. Supõe-se que o item esteja em condições de desempenhar a função requerida no início do intervalo de tempo. Também é chamada de taxa de exito. (NBR 5462-1994 2.13.1.).

\section{CONTROLE DA CONDIÇÃO OU MONITORAÇÃO DA CONDIÇÃO -} (Condition Monitoring) - Comprovação do estado real de um item através do controle (monitoração) sistemático periódico ou contínuo de um parâmetro significativo. Eqüivale ao termo Controle do estado ou Monitoração do estado.

"COZIMENTO" - Quinta fase do processo de celulose da VCP_LA. Aqui ocorre o processo de polpação alcalina Kraft, com a digestão da madeira através de sua reação com várias substâncias, entre elas o licor branco, ou seja, hidróxido de sódio e sulfeto de sódio. A lignina é retirada e as fibras liberadas, resultando em licor negro e celulose marrom.

CRITICIDADE - O quanto um item é crítico ou influencia o funcionamento de uma máquina ou sistema. O efeito de um mau funcionamento ou falha de um item para o desempenho de um sistema.

“CRONOGRAMA MASTER" - Gráfico de Gantt composto pelas principais atividades operacionais e de manutenção a serem realizadas em um evento/ intervenção. Neste trabalho, o cronograma master representa o plano de parada de toda a produção de celulose.

"CULTURA DE MUDANÇA" - Ambiente organizacional onde a versatilidade, flexibilidade, prontidão e busca pela mudança contínua é inerente a todos os profissionais e ações realizadas. Um ambiente apto a mudar sempre, sem resistências, barreiras ou restrições. 
CURVA DA BANHEIRA (Bathtub Curve) - Representação gráfica característica que relaciona a Taxa de Falhas de um Item com seu Tempo de Operação, onde o equipamento estudado passa pelas três fases de sua vida: partida ou mortalidade infantil (falhas prematuras), vida útil ou vida adulta (falhas por desgaste). Deve-se levar em conta que as modernas técnicas de qualidade estão fazendo o possível para que a mortalidade infantil seja reduzida ou eliminada e que as máquinas bem mantidas com programas de preditiva monitorados as vezes levam muito tempo para atingir o que se chama "fim de vida útil" ou "fím de vida econômica". Além disto, certos bens, tidos como descartáveis, outros trocados por desejos de algo mais moderno, ou outros de fácil reposição, fazem com que muitos casos o fim de vida útil não seja atingido. Neste caso, sobram apenas as falhas aleatórias ou seja, a vida adulta, que é o período que é estudado em confiabilidade.

CURVA DE FALHA - Curvas utilizadas para representar os modos de falha de equipamentos e sistemas industriais. $\mathrm{Na} R C M$ são definidas seis curvas de falha, sendo um exemplo a "curva da banheira" (MOUBRAY, 2000).

"DA,CASA" - Neste trabalho, profissionais da VCP_LA.

"DESAERAR" - Processo mecânico utilizado para a retirada ou redução do oxigênio dissolvido em meio líquido. A água desaerada é utilizada em caldeiras, por exemplo, já que o oxigênio presente na água causa oxidações ou ataques indesejados nos seus internos.

DESAFIO - Ação de desafiar, competição, superação. Um resultado melhor que o proposto ou conveniente (meta).

"DESCASCAMENTO" - Segunda fase do processo de celulose da VCP LA. As cascas das toras são retiradas pelo tambor descascador, através do atrito entre elas e delas com as paredes do tambor. Como as cascas têm poucas fibras, tornando sua utilização na fabricação da celulose pouco rendosa, é utilizada para queima nas CF.

DESEMPENHO - Informação de resultados numéricos obtidos dos processos e produtos que permite avaliar a comparação em relação a metas, padrões resultados do passado e com outros processos e produtos. Mais comumente os resultados expressam qualidade, eficiência e tempo, e podem ser apresentados em termos financeiros ou não. Normalmente o desempenho é avaliado e identificado de quatro modos: desempenho operacional, desempenho da qualidade do produto, desempenho relativo ao cliente, e desempenho financeiro.

DIAGNÓSTICO - (Diagnosis) - Dedução da natureza de uma falha baseada nos sintomas detectados. Em manutenção a identificação da causa provável de uma falha ou de um defeito, com a ajuda de dados levantados, experiência e raciocínio. Esperase que quem está fazendo o diagnóstico use ferramentas da qualidade adequadas, como Diagramas de Ishikawa, MASP, Pareto, etc. Na área da qualidade, diagnóstico é a atividade que procura descobrir a causa ou as causas da deficiência da qualidade em um produto, bem ou serviço. 
"DIGESTOR" - Equipamento onde ocorre o processo de cozimento químico da madeira para a extração da celulose. Ver também vaso de pressão.

DISPONIBILIDADE - (Availability) - É a probabilidade de que um item possa estar disponível para utilização em um determinado momento ou durante um determinado período de tempo. Capacidade de um item para desempenhar a sua função em um determinado momento, ou durante um determinado período de tempo, nas condições e rendimento definidos. A disponibilidade de um item não implica necessariamente que esteja funcionando, mas que encontra-se em condições de funcionar. Uma medida prática da disponibilidade de um item como parâmetro de referência é definida pela relação entre o Tempo de Operação (tempo rela de funcionamento correto produzindo). É a probabilidade de uma máquina estar produzindo ou disponível para produzir. Normalmente é calculada pela razão entre o "tempo calendário total", ou TMEF/(TMEF+TMPR).

DISPONIBILIDADE - Capacidade de um item estar em condições de executar um certa função em um dado instante ou durante um intervalo de tempo determinado, leyando-se em conta os aspectos combinados de sua confiabilidade, mantenabilidade e suporte de manutenção, supondo que os recursos externos requeridos estejam assegurados. O termo "disponibilidade" é usado como uma medida do desempenho de disponibilidade. (NBR 5462-1994).

DISPONIBILIDADE - Disponibilidade que um equipamento não esteja disponível para produzir. Não esqueça: indisponível é o que você pode usar. É expressa em porcentagem. É o complemento para a unidade da disponibilidade. Assim DISP + INDI $=1$. Representação INDI. Pode também ser expressa como a ralação entre o tempo de manutenção com o equipamento parado e a soma do tempo de operação mais o tempo de manutenção com o equipamento parado.

“DUOFORMER" - Equipamento que caracteriza a segunda etapa do processo de produção de papel da VCP_LA, caracterizado por um sistema de drenagem e formação da folha, onde a massa resultante da primeira etapa incide sobre telas sintéticas e o excesso de água é removido por gravidade e ação de elementos mecânicos desaguadores.

EMPOWERMENT - Habilitar, capacitar. Neste trabalho, investir no treinamento e desenvolvimento de todos os envolvidos no negócio.

EMPREENDIMENTO (Project) - É um evento específico, não-rotineiro, como por exemplo a montagem de uma planta fabril, a construção de um prédio ou uma parada de manutenção em uma unidade de processo. É um projeto completo que abrange as etapas de concepção, avaliação de mercado, estudos de viabilidade, projeto básico e detalhamentos, gerência de suprimentos, obras civis e montagem eletromecância, testes e pré-operação.

"ENROLADEIRA" - Equipamento que caracteriza a etapa final do processo de produção de papel da VCP_LA. A folha de papel formada na máquina é enrolado em forma de grandes rolos, os quais seguem para as seções de acabamento. 
EVENTO - Acontecimento. Neste trabalho, "eventos de parada do processo".

EXCELÊNCIA - Na área da qualidade, o estado de manter ou superar os concorrentes, de manter ou superar as expectativas do cliente.

“EXPEDIÇÃO" - Setor da VCP_LA onde os papéis produzidos são enviados aos clientes por transporte rodoviário, enquanto os papéis destinados a exportação são acondicionados em containers e encaminhados ao Porto de Santos, no litoral sul do Estado.

"EXTRAÇÃO E EXPEDIÇÃO" - É a área onde ocorre o processo de extração de celulose da VCP_LA, o qual produz fardos prensados de celulose com $55 \%$ de consistência, os quais são colocados em um pátio e encaminhados as outras Unidades Industriais da VCP.

"FACILITADOR" - Gestor. Neste trabalho, gerente dos Times de trabalho das CT.

FALHA (Failure) - Perda da capacidade de um Item para realizar sua função espećífica. Pode eqüivaler ao termo Avaria. É a diminuição total ou parcial da capacidade de uma peça, componente ou máquina de desempenhar sua função durante um período de tempo, onde o item deverá sofrer a manutenção ou ser substituído. A falha leva o item ao estado de indisponibilidade.

"FATOR DE RISCO" - No contexto deste trabalho, toda e qualquer atividade realizada em um evento de parada planejada da planta que, na opinião da equipe responsável, oferece riscos ao cumprimento dos prazos, custos e metas.

FERRAMENTAS - Em manutenção, as chaves de boca, os aparelhos, as técnicas apropriadas que se utiliza para que um reparo seja mais bem e mais rapidamente executado.

FERRAMENTAS - Na área da qualidade, os recursos e as técnicas que se utiliza para se obter a qualidade.

FERRAMENTAS - Na área de Engenharia de Manutenção as técnicas que são utilizadas para que a manutenção seja melhor planejada e executada, com menor freqüência, com menores despesas e com aumento de disponibilidade do item, máquina ou sistema. Po exemplo, FMEA, Análise Estatística, Planejamento e Controle da Produção, Programas de Qualidade, Árvore de Falha, etc.

"FIBRA CURTA" - Fibra de madeiras de árvores folhosas, como o Eucalipto.

"FIBRA LONGA" - Fibra de madeiras de árvores coníferas, como o Pinos.

"FIBRA" - Neste trabalho, o enfoque é a fibra da madeira. Normalmente, a madeira é composta de fibras, água e outras substâncias indesejáveis para o processo de produção de celulose (IPT-SENAI, 1988). 
"FORMA DE CONTROLE" - Neste trabalho, ação ou providência para o planejamento e controle de uma atividade ou intervenção considerada crítica. Ver plano de ação.

"GAMAGRAFIA" - Teste de inspeção não destrutivo para detecção de defeitos localizados em materiais, realizado por equipamentos especiais.

"GRAMATURA" - Espessura da folha de papel.

HOMEM-HORA (Hh) - Quantidade de empregados que estão trabalhando multiplicado pelo tempo, medido em horas. Assim com 10 empregados trabalhando um período de 5 horas temos $50 \mathrm{Hh}$.

"IN LOCO" - No local da atividade ou intervenção.

INSPEÇÃO - Atividades tais como: medição, exame, ensaio, verificação com calibres ou padrões, de uma ou mais características de uma entidade, e a comparação dos resultados com requeridos especificados, a fim de determinar se a conformidade para cada um destas características é obtida. (NBR ISSO 8402-1994).

INTERFACE - Interdependência entre sistemas, instalações e sub-processos.

INTERVENÇÃO - Toda e qualquer atividade realizada que caracterize uma interferência na planta fabril ou no processo produtivo.

"KRAFT" - Processo de cozimento das fibras da madeira a partir da adição de hidróxido de sódio e sulfeto de sódio (também conhecido como processo sulfato). Palavra de origem alemã para denotar "papel resistente".

"LAVAGEM" - Sexta fase do processo de celulose da VCP_LA. Nessa etapa, o principal objetivo é a remoção das substâncias resultantes do cozimento ainda presentes nas fibras. Nesta planta, o sistema de lavagem possui dois estágios de prébranqueamento, formados por dois reatores (um de oxigênio e um de peróxido de hidrogênio) e, também, é constituído por três lavadores pressurizados, um lavador a vácuo e uma prensa lavadora.

"LICOR" - Solução de lignatus de sódio gerada no processo de polpação da celulose. Subproduto reutilizado no processo de recuperação química. Nas diversas fases do processamento têm-se o licor negro, branco e verde, cores definidas pelas substâncias presentes e características de processamento.

“LIMPADOR DE AR" - Cilindro pneumático para limpeza automática dos bocais de entrada de ar da Caldeira de Recuperação. Utilizados somente em CR devido as características da queima realizada na fornalha.

"LIMPEZA OPERACIONAL" - No contexto deste trabalho, a eliminação ou redução de sujeira, escórias, material de rejeito, produtos de oxidação ou incrustação para que um item trabalhe nas melhores condições de utilização. 
LISTA DE VERIFICAÇÃO (Check list) - Documento no qual estão registrados todos os procedimentos e valores a serem verificados ou testados. $\mathrm{Na}$ área da qualidade, documento através do qual se registra e se controla determinados parâmetros do processo.

"LIVRO DE OCORRÊNCIAS" - Registros de ocorrências de intervenções em equipamentos, sem uma prévia programação dos serviços onde são associados os custos relativos à mão de obra, peças e custos gerais.

MANTEC - Sistema computadorizado abrangente para gerenciamento de engenharia e manutenção. Voltado para o usuário final, apresenta interface amigável, oferecendo funções gerenciais e técnicas integradas ao sistema (SEMAPI, 1998).

MANTENABILIDADE - Capacidade de um item ser mantido ou recolocado em condições de executar as suas funções requeridas, sob condições de uso especificadas, quando a manutenção é executada sob condições determinadas e mediante procedimentos e meios prescritos. O termo "mantenabilidade" é usado como, uma medida do desempenho de mantenabilidade. (ABNT NBR 5462-1994).

MANUTENABILIDADE - O mesmo que mantenabilidade e manutenibilidade.

META - Alvo, padrão, objetivo ou diretriz. Resultado tido como suficiente.

MISSÃO - A razão de ser de uma organização, as necessidades sociais a que ela atende e seu foco fundamental de negócios. (NBR-ISSO 14004).

“MIX" - Neste trabalho, variedade de produtos oferecidos ao mercado consumidor.

"MOMENTOS DE OPORTUNIDADE OPERACIONAL" - Períodos de tempo em que se reduz ou se interrompe totalmente o processo de fabricação (processamento normal) por um motivo operacional. Como exemplos, limpezas operacionais, trocas de fabricação e paradas setoriais de subprocessos, ou seja, sem o registro de indisponibilidades devido a falhas em equipamentos ou sistemas. Vide parada programada ou planejada.

"MULTICICLONE" - Separador de cinzas ou partículas (resultantes dos processos de queima nas caldeiras). A partir da centrifugação, as partículas pesadas são retidas e os gases liberados para as chaminés.

MULTIFUNÇÃO - Capacidade de um funcionário para desempenhar os trabalhos próprios de mais de um oficio ou especialidade.

“ORDEM DE SERVIÇO” - Instrução escrita que define o trabalho que deve ser realizado pela organização da manutenção.

OUTAGE - Ver parada geral.

"PADRÕES LEGAIS" - Neste trabalho, valores ideais recomendados para as condições e características inerentes a segurança operacional dos equipamentos e sistemas. Como exemplos: espessuras de tubulações em vasos de pressão. 
PARADA - Situação em que se coloca uma instalação industrial ou parte dela, por diversos motivos. Um destes motivos é a manutenção programada.

"PARADA DA PLANTA" - Paralização do processo produtivo desenvolvido em uma planta fabril.

PARADA DE EMERGÊNCIA - Vide parada não programada.

PARADA GERAL (Outage) - Parada devida a interrupção programada de Operação de um Item ou Processo de Fabricação.

PARADA GERAL (Turnaround) - Situação de um conjunto de Itens ou Processo de Fabricação no qual são efetuadas periodicamente revisões e reparos concentrados e programados em um determinado período de tempo. Eqüivale ao termo Reparo Geral quando este se refere a uma Instalação ou Unidade com caráter periódico.

PARADA IMPREVISTA - Vide parada não programada.

PARADA NÃO PROGRAMADA (Forced outage) - Parada devida a interrupção não programada da Operação de um Item ou Processo de Fabricação.

PARADA PROGRAMADA OU PLANEJADA - Colocação de uma unidade, máquina, instalação ou sistema dentro de uma programação previamente acertada, por diversos motivos, por exemplo, por falta de matéria-prima, por falta de encomendas ou para manutenção. Note que parada por falta de matéria-prima não deve ser computada com indisponibilidade, pois a questão é operacional (daí a origem do termo "momento de oportunidade" para a Manutenção).

PARADA SETORIAL - Parada de um subprocesso de fabricação, Item ou equipamento. Normalmente, esse tipo de Parada não requer a interrupção da produção, mas sim a redução da capacidade produtiva (ritmo normal de produção).

"PARALELO" - Neste trabalho, entrar em paralelo significa o atendimento às condições ideais de operação (temperatura, pressão etc.) para que a produção seja contínua na qualidade desejada.

"PAREDE DA FORNALHA" - Painel único de tubos d'água junto as paredes da fornalha de uma caldeira.

"PARTE DE PRESSÃO DA CR" - Áreas internas e confinadas pressurizadas positivamente como, por exemplo, a fornalha.

"PARTIDA DA PLANTA" - Inicio de operação da planta fabril após sua parada (cessamento da produção).

"PÁTIO DE MADEIRAS" - Na VCP_LA, é uma área composta de partes ou plantas fabris constituintes do processo de produção da celulose: Recebimento, Descascamento, Picagem, Classificação e Estocagem. Vide capítulo 2 deste trabalho. 
"PESSOA-CHAVE" - Agente de mudanças, formador de opinião. Neste trabalho, profissional cuja função é considerada estratégica e a posição perante a Organização fundamental para o fluxo de informações interno.

"PICAGEM" - Terceira fase do processo de celulose da VCP_LA. Consiste na fragmentação das toras, formando os cavacos, através de um picador do tipo disco com múltiplas facas. A redução das toras a cavacos facilita o transporte e a impregnação do licor na etapa de cozimento.

PLANEJAMENTO E CONTROLE DE MANUTENÇÃO - É um órgão ou função, dentro da empresa, a qualquer nível, que efetua a programação e o controle dos trabalhos executados pelas equipes de manutenção. Representado em diversos documentos como PCM e em outros como PPCM.

PLANEJAMENTO ESTRATÉGICO - Tem por finalidade garantir a sobrevivência da empresa. É o processo de determinar os objetivos e decidir quais recursos serão utilizados e como chegar até a meta. De como atingir a visão que temos da empresa no futuro.

PLANO DE AÇÃO - Trabalho de preparação para qualquer empreendimento, determinando roteiros e métodos de trabalho. Ele estabelece o que deve ser feito para atingir uma meta ou evitar uma falha.

PLANTA FABRIL - No contexto deste trabalho, área que compreende os equipamentos, máquinas e instalações diversas dos processos e subprocessos. O mesmo que instalação industrial ou Unidade.

POLÍTICA DE MANUTENÇÃO - (Maintenance Policy) - Estratégia que rege as decisões a gerência de uma organização de Manutenção. É da responsabilidade do Gerente de Manutenção determinar a política adequada à empresa onde trabalha, usando todos os argumentos e técnicas existentes para fundamentar sua exposição.

POLIVALÊNCIA - (Multiskill) - Capacidade de um funcionário para desempenhar os trabalhos próprios de mais de um ofício ou especialidade.

"POLPAÇÃO" - Transformação de matéria-prima na polpa com que se fabrica o papel. Processo de cozimento realizado no Digestor. Ver Kraft.

"PORTAS DE VISITAS" - Ver bocas de visitas.

"PÓS-SECAGEM" - Sexta etapa do processo de produção de papel da VCP_LA, que ocorre de forma idêntica a pré-secagem. Ela é necessária devido a aplicação de amido na Speed Sizer, que aumenta o teor de umidade, o que é indesejável.

"PRECIPITADOR ELETROSTATICO" - Separador de cinzas ou partículas (resultantes dos processos de queima nas caldeiras). A partir de um processo elétricomecânico, as partículas pesadas são retidas e os gases liberados para as chaminés. Mesma função do Multiciclone.

"PRENSAS DESAGUADORAS" - Equipamento que caracteriza a terceira etapa 
do processo de produção de papel da VCP_LA. Após a folha formada, a função das prensas é remover mecanicamente a máxima quantidade possível de água, esta fase é conhecida como prensagem úmida.

"PREPARAÇÃO DE MASSA" - Esta é a primeira etapa do processo de produção de papel da VCP_LA, onde ocorre a refinação da massa de celulose adicionando-se todos os componentes constituintes do papel, tais como: $P C C$, amidos de milho, colas sintéticas, agentes para retenção e drenagem, alvejante óptico, corantes, microbicidas, cloreto de sódio, entre outros.

"PRÉ-SECAGEM" - Quarta etapa do processo de produção de papel da VCP_LA. Aqui a remoção fina da água dá-se por evaporação, com a aplicação de calor. A secagem é obtida com a passagem da folha de papel sobre cilindros aquecidos a vapor (VMP), onde o completo contato entre a folha e a superfície dos cilindros é garantido por meio de telas secadoras.

PRÓ-ATIVO - Neste trabalho, qualidade inerente as pessoas. Atuação com o o,bjetivo focado na melhoria contínua, comprometimento etc.

"PROJETO REPENSAR" - Nome dado ao processo de reestruturação organizacional das empresas do Grupo VCP, iniciado em 1994. Transformação organizacional, reengenharia.

"PROJETO REVITALIZAÇÃO" - Projeto idealizado pelo Grupo VCP em 2001 para a consolidação de valores essenciais para sua política de atuação. Como exemplos desses valores: Pessoas, Clientes, Provedores, Meio Ambiente etc.

QUEBRA ZERO - Filosofia ou conceito da Qualidade Total. Visa estabelecer uma meta ideal para o índice de quebras ou falhas. O mesmo princípio do Zero Defeitos.

"REBOBINADEIRA” - É a máquina utilizada para conversão dos grandes rolos, produto retirado da máquina, em bobinas com larguras e diâmetros especificados para o fornecimento. Faz parte do processo de acabamento da VCP_LA.

"RECEBIMENTO" - Primeira fase do processo de celulose da VCP_LA. A madeira é pesada e inspecionada quanto ao seu diâmetro e comprimento, além de serem verificados o tempo de corte e os aspectos visuais.

“REDUÇÃO DA PRODUÇÃO" - Neste trabalho, redução da capacidade produtiva sem o cessamento total da produção.

REENGENHARIA - Readequação ou transformação organizacional. Enxugamento da estrutura da Organização (DRUCKER, 1995).

RELIABILITY - Confiabilidade (NBR 5462-1994).

REPARO - Parte da manutenção corretiva na qual são efetuadas as ações de manutenção efetiva sobre um item, excluindo-se os atrasos técnicos. (ABNT NBR 5462-1994). 
"REPINAGEM" - Na VCP_LA, manutenção corretiva nas paredes da fornalha. Consiste na soldagem de pinos de aço aos tubos da parede da fornalha, que têm a função de aumentar a vida útil dos tubos e principalmente de propiciar uma melhor troca térmica entre os tubos da parede com a camada de fundido (licor em alta temperatura, aproximadamente $1.800^{\circ} \mathrm{C}$ ).

"RETRABALHO" - Atividade originada de uma falha no planejamento ou execução de outra atividade. Em alguns casos, retrabalho significa perda (de tempo, produção, eficiência etc.).

SEGURANÇA - As medidas para a conservação da vida humana, suas capacidades e a prevenção de danos para os itens, máquinas ou sistemas, em sintonia com as necessidades de manutenção e de preservação da integridade de quem está como usuário ou próximo.

SEGURANÇA OPERACIONAL - Operação dos equipamentos e sistemas com controle total e confiabilidade. Vide segurança.

SHUTDOWN - Parada durante pequenos períodos ou de partes ou plantas constituintes do processo produtivo. Ver parada setorial.

SISTEMAS ESPECIALISTAS (SE) - Tecnologia projetada para codificar o conhecimento de um especialista em um programa de computador na forma de regras SE...ENTÃO - (CAMPOS; 1999).

SOBRESSALENTE - (Spare Part) - Peça, componente, conjunto, equipamento ou máquina pertencente a um item de ordem superior que seja susceptível de substituição por rompimento, desgaste ou consumo.

"SPEED SIZER" - Equipamento que caracteriza a quinta etapa do processo de produção de papel da VCP_LA. É uma prensa de colagem externa, onde o amido superficial é aplicado a folha. Basicamente, há distribuição de uma fina camada de amido na superfície do papel através do revestimento indireto, por barras aplicadoras.

TAXA DE FALHAS - Define-se como sendo a relação entre um incremento do número de falhas ocorridas e o incremento correspondente de tempo, em qualquer instante da vida de um sistema, subsistema ou equipamento.

"TEMPO DE MANUTENÇÃO EM PARADA" - Período de tempo no qual se realiza a Manutenção, enquanto o item está Parado/ fora de serviço. Compõem-se da execução, preparação e espera.

"TEMPO DE PARADA" - Período de tempo em que um Item não está em Operação.

"TIJOLOS REFRATÁRIOS" - Material isolante especial que retém energia térmica. Na VCP_LA, é utilizado em forma de tijolos para o isolamento interno do Forno de Cal Rotativo.

"TORRE DE ESTOCAGEM" - Tanque para estocagem de celulose. Após o 
processamento da celulose, finalmente tem-se a estocagem da celulose branqueada $A D$ em baixa consistência, para a utilização direta nas MP ou para seu desaguamento e conformação para o transporte.

"TRATATIVA" - Tratado, ajuste, pacto. Neste trabalho, forma, atuação, plano de ação. Representa a maneira como uma atividade ou ação é tratada. Ver plano de ação.

“TRIP" - Neste trabalho, significa o desligamento ou desarme total, não esperado, de um equipamento ou instalação.

"TROCA DE FABRICAÇÃO" - Mudança do produto fabricado de acordo com um Plano de Produção (PCP).

UNIDADE (Plant) - Sistema integrado de itens que constituem uma unidade funcional de produção ou serviços.

UNIDADE DE PROCESSO - Conjunto de sistemas operacionais para geração de um' produto ou serviço. Ex. Aciaria, Utilidades, etc.

UTILIDADES (Utility, utilities) - Um dos suportes à produção, que fazem parte do processo, mas não fazem parte do produto acabado, como por exemplo, o abastecimento de ar comprimido, eletricidade, água, vapor, gás, etc., bem como o nome genérico dados às estas instalações específicas de onde o meio provem.

"VASOS DE PRESSÃO" - São equipamentos que contêm fluidos sob pressão interna ou externa. Neste trabalho, reservatório contendo fluídos sob pressão acima ou abaixo da pressão atmosférica (Norma Regulamentadora NR13).

VIDA ÚTIL - É o período de tempo durante o qual um sistema, subsistema ou equipamento desempenha sua função com uma taxa de falhas aceitável.

VISÃO - (Vision) - Estado que a organização deseja atingir. A visão tem intenção de propiciar o direcionamento dos rumos de uma organização. (ISO 14044).

VISÃO GLOBAL - Noção do todo. Análise de um dado, atividade ou informação sob um ponto de vista multiespecialista e multifuncional.

VISÃO HOLÍSTICA - Observação e análise de um evento ou processo que consideram o todo e as inter-relações de suas partes.

VISÃO SISTÊMICA - Visão orgânica ou lógica de um sistema. Coerente com determinada linha de pensamento e/ou ação.

ZERO DEFEITOS - Filosofia empregada pelo TPM, onde procura-se que as máquinas não tenham defeito e não falhem. Isto deve ser entendido como "Zero Defeitos Inesperados ou Imprevistos" pois com boa prática de acompanhamento, com o operador interagindo com a máquina e com a manutenção dentro do processo, com bons métodos de manutenção preventiva e preditiva as ocorrências de manutenção corretiva podem ser quase todas suprimidas. 